RUBENS BARDELLI JUNIOR

DESENVOLVIMENTO DE UM MECANISMO AUTOMÁTICO DE CORTE POR FIO ABRASIVO DE CERÂMICAS PIEZELÉTRICAS 
RUBENS BARDELLI JUNIOR

\section{DESENVOLVIMENTO DE UM MECANISMO AUTOMÁTICO DE CORTE POR FIO ABRASIVO DE CERÂMICAS PIEZELÉTRICAS}

Dissertação apresentada à Escola Politécnica da Universidade de São Paulo para obtenção do título de Mestre em Engenharia

Área de Concentração:

Engenharia Mecatrônica

Orientador: Prof. Dr. Julio Cezar

Adamowski 
RUBENS BARDELLI JUNIOR

\section{DESENVOLVIMENTO DE UM MECANISMO AUTOMÁTICO DE CORTE POR FIO ABRASIVO DE CERÂMICAS PIEZELÉTRICAS}

Dissertação apresentada à Escola Politécnica da Universidade de São Paulo para obtenção do título de Mestre em Engenharia 
Este exemplar foi revisado e alterado em relação à versão original, sob responsabilidade única do autor e com a anuência de seu orientador.

São Paulo, 22 de fevereiro de 2008.

Assinatura do autor

Assinatura do orientador

\section{Bardelli Junior, Rubens}

Desenvolvimento de um mecanismo automático de corte por fio abrasivo de cerâmicas piezelétricas / R. Bardelli Junior. -- ed. rev. -- São Paulo, 2008.

$99 \mathrm{p.}$

Dissertação (Mestrado) - Escola Politécnica da Universidade de São Paulo. Departamento de Engenharia Mecatrônica e de Sistemas Mecânicos.

1.Cerâmicas 2.Abrasão 3.Usinagem 4.Ultra-som 5.PZT 6.Fio de corte I.Universidade de São Paulo. Escola Politécnica. Departamento de Engenharia Mecatrônica e de Sistemas Mecânicos II.t. 
Dedico este trabalho à minha noiva Fernanda e minha família, pelo apoio e incentivo durante este período. 


\section{AGRADECIMENTOS}

Ao meu orientador, Prof. Dr. Julio Cezar Adamowski, que desde a graduação tem me orientado com perfeição em relação aos rumos que devo seguir em minha carreira acadêmica e profissional.

A minha família, que tornou possível o meu sonho de fazer parte de uma das melhores instituições de ensino do país.

A minha noiva Fernanda, por todo o apoio, incentivo e compreensão durante todo esse período tão corrido.

Ao Sr. Nilson Noris Francischetti, pelas maravilhosas explicações na área eletrônica. Aos meus amigos, Mario, Davi, Heitor, Pedro e Marco Aurélio, pelos momentos de descontração e pelas discussões construtivas. E a todos que colaboraram direta ou indiretamente na execução deste trabalho. 


\section{RESUMO}

O objetivo deste trabalho é apresentar uma solução funcional de um mecanismo de corte de cerâmicas por abrasão, para possibilitar a construção de transdutores piezocompósitos de ultra-som através do método "Dice and Fill". Esse trabalho apresenta a teoria necessária para entender como funciona o desgaste por abrasão em cerâmicas e quais as variáveis que mais influenciam nesse desgaste. São apresentados também os requisitos e as características do corte que devem ser feitos nas piezocerâmicas, bem como os cálculos de dimensionamento da taxa de desgaste através da fórmula de desgaste de Archard. Através dos resultados experimentais e práticos essa dissertação mostra como regular o equipamento para funcionar em sua máxima eficiência.

Palavras-chave: Mecanismo de corte de cerâmicas. Desgaste por abrasão. 


\begin{abstract}
The objective of this work is to describe one great and simple mechanism that is capable of machining PZT ceramic by wear. That mechanism will be used to produce piezocomposites transducers more easily by the "Dice and Fill" method. This work also explains how the ceramic material can be worn and which variables are important in this wear. It is also presented the requirements and characteristics of the ceramic cuts to build an ultrasonic transducer and showed how to predict the wear in the ceramic by using the Archard's formula. Finally all parts of the cut mechanism are described and the practical results of the study are used to setup the mechanism to work in the maximum efficiency.
\end{abstract}

Keywords: Ceramic cut mechanism. Wear. 


\section{LISTA DE FIGURAS}

Figura 1.1 - Fio de corte adiamantado ................................................... 18

Figura 1.2 - Metodologia utilizada neste trabalho .........................................22

Figura 2.1 - Esquema de um transdutor piezelétrico .....................................25

Figura 2.2- Método "Dice and Fill" ....................................................... 31

Figura 2.3 - Resultado do método "Dice and Fill" .......................................... 31

Figura 2.4 - Impedância elétrica de um disco de cerâmica de $20 \mathrm{~mm}$ de diâmetro e 2

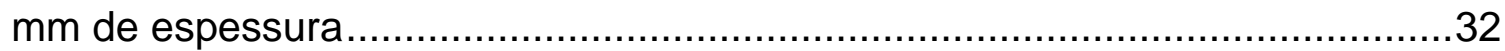

Figura 2.5 - Impedância elétrica de um material compósito 1-3 de 20 mm de diâmetro

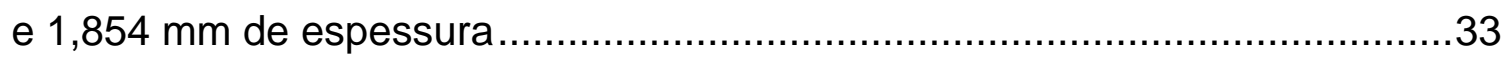

Figura 2.6 - Relação geométrica dos cortes da cerâmica .................................33

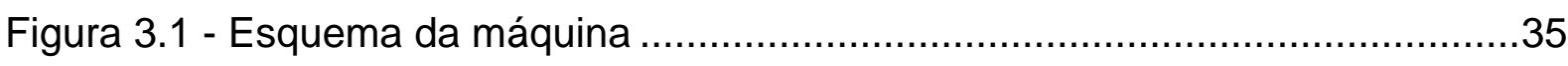

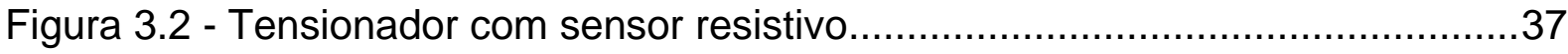

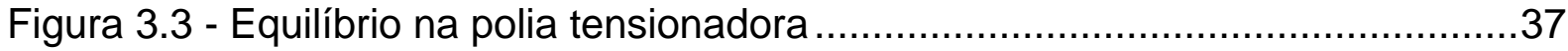

Figura 3.4 - Relação ângulo x força normal no fio ............................................. 38

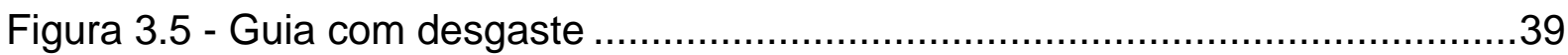

Figura 3.6 - Posicionamento das guias na máquina.....................................40

Figura 3.7 - Balanço de Forças na Região de Corte .......................................41

Figura 3.8 - Conversão de tensão normal em tensão cortante...........................42

Figura 3.9 - Distribuição de tensão na interface cerâmica e abrasivo .....................43

Figura 3.10 - Fio de corte corretamente tensionado......................................44

Figura 3.11 - Fio de corte não tensionado ................................................. 44

Figura 3.12 - Sistema Mecânico do Sensor............................................... 45

Figura 3.13 - Esquema do controlador ................................................ 47

Figura 3.14 - Zonas de controle de tensão................................................48

Figura 3.15 - Estado inicial dos carretéis ................................................. 51

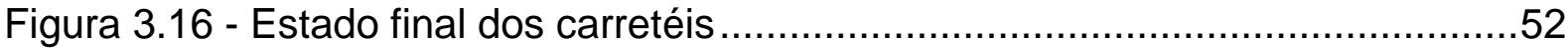

Figura 3.17 - Fluxograma do controle da tensão no fio ....................................53

Figura 3.18 - Fluxograma das ações do controlador ........................................54

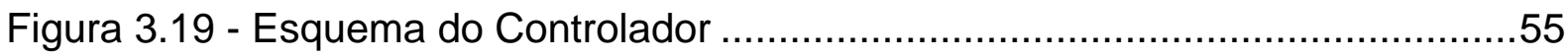

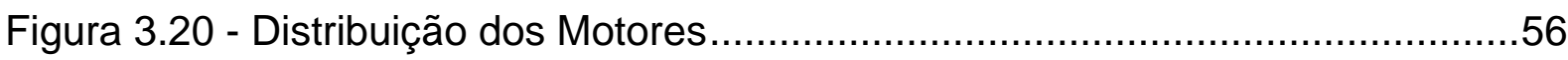

Figura 3.21- Sinais de comando para os Motores para relação de transmissão 1:1.57 
Figura 3.22 - Sinais de comando para os Motores para relação de transmissão 2:1 .57

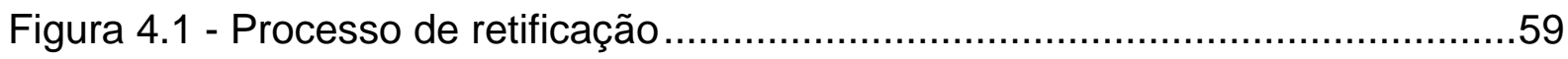

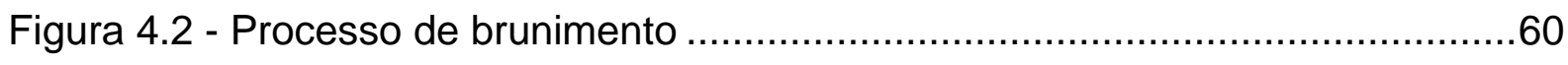

Figura 4.3 - Processo de lapidação ........................................................ 61

Figura 4.4 - Mecanismos de desgaste ...................................................63

Figura 4.5 - Relação $\mathrm{Ha} / \mathrm{Hs}$ x volume desgastado ...........................................65

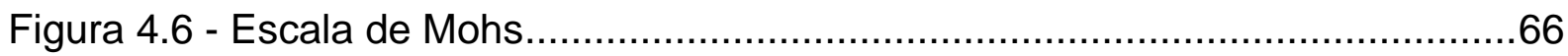

Figura 4.7 - Taxa de desgaste a abrasão a 2 corpos com velocidade relativa.........67

Figura 4.8 - Taxa de desgaste a abrasão a 3 corpos com velocidade relativa 75 $\mathrm{mm} / \mathrm{s}$ x tamanho da partícula do abrasivo..............................................6 68

Figura 4.9 - Coeficiente de desgaste $x$ velocidade de deslizamento ......................69

Figura 4.10 - Taxa de desgaste $\mathrm{x}$ umidade relativa ...................................... 70

Figura 4.11 - Folga de Corte do Processo ..................................................... 75

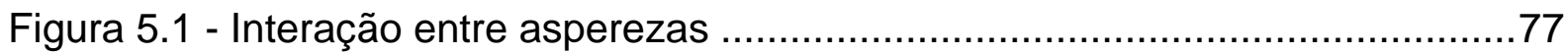

Figura 6.1 - Gráfico do tempo de usinagem x velocidade tangencial do fio de corte 81 Figura 6.2 - Gráfico do tempo de usinagem x freqüência de mudança de direção do

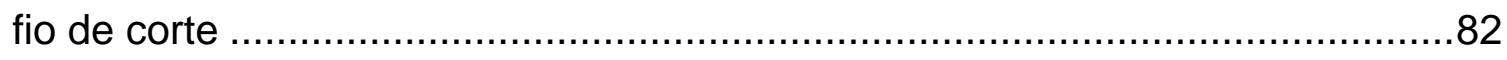

Figura 6.3 - Gráfico da Relação do Tamanho do Grão do Abrasivo x Tempo de

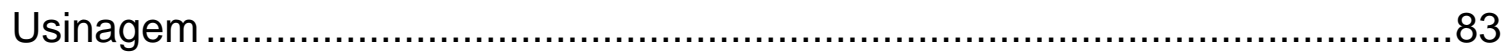

Figura 6.4 - Gráfico do diâmetro do fio de corte x número de reutilizações do fio.....84 Figura 6.5 - Desenho da cerâmica a ser usada no procedimento .......................... 85

Figura 6.6 - Resultado do procedimento de corte ........................................ 86

Figura 6.7 - Localização dos cortes na cerâmica ............................................. 86

Figura 6.8 - Seqüência de corte da cerâmica ........................................... 87

Figura 6.9 - Processo de usinagem do canal na cerâmica.................................88

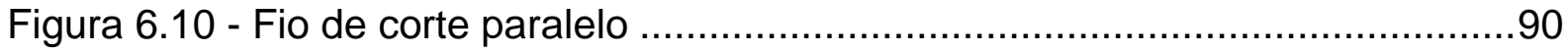

Figura 6.11- Ângulo de ataque do fio para aumento da taxa de remoção de material 90

Figura 6.12 - Foto do primeiro protótipo feito no mecanismo de corte ...................91 


\section{LISTA DE TABELAS}

Tabela 8.1 - Parâmetros de Regulagem do Mecanismo de Corte.

.92 


\section{LISTA DE SÍMBOLOS}

Raio de uma aspereza

Tração no fio

Tração na primeira parte do Fio de Corte, antes do ponto B Tração na segunda parte do Fio de Corte, após o ponto B Ponto onde fio toca a cerâmica a ser cortada.

Força peso

Taxa total de desgaste

Dureza do material cerâmico

Ângulo de tracionamento superior do fio

Ângulo entre a força peso e a linha de referência y

Ângulo de tracionamento inferior do fio

Força elástica do sensor

Dureza do abrasivo

Dureza da superfície

Constante de proporcionalidade

Volume de material desgastado

Média de material destacado por unidade de distância

Carga normal de desgaste

Coeficiente de desgaste

Média de material destacado

Ângulo medido pelo Sensor da máquina

Tensão limite elástica axial

Carbeto de silício

Nitreto de silício

Fator de acoplamento eletromecânico

Velocidade tangencial do carretel 1

Velocidade tangencial do carretel 2

Diâmetro do carretel 1 


$\begin{array}{ll}D_{2} & \text { Diâmetro do carretel 2 } \\ r_{1} & \text { Raio do carretel 1 } \\ r_{2} & \text { Raio do carretel } 2 \\ Q_{m} & \text { Fator de qualidade mecânico } \\ Q_{e} & \text { Fator de qualidade elétrico } \\ P W M & \text { "Pulse width modulation" } \\ F(T) & \text { Impulso unitário } \\ I & \text { Momento de inércia } \\ \text { a } & \text { Comprimento do braço do mecanismo } \\ b & \text { Comprimento do braço da polia } \\ R & \text { Raio do contra peso } \\ M & \text { Massa do contra peso } \\ d & \text { Distância entre o pólo O e o baricentro G da massa. } \\ K_{d} & \text { Ganho do controlador derivativo } \\ K_{p} & \text { Fator de acoplamento transversal } \\ T c & \text { Tensão Cortante } \\ F n & \text { Força Normal } \\ A f & \text { Área de contato entre o fio e a cerâmica } \\ H(s) & \text { Controlador a ser utilizado } \\ G(s) & \text { Planta a ser controlada } \\ \tau_{r e s} & \text { Resultante dos Momentos aplicados ao Sistema } \\ \psi & \text { Ângulo de inclinação do fio de corte } \\ V_{f} & \text { Ângulo de inclinação do fio de corte antes do Ponto B } \\ \psi_{2} & \text { Ângulo de inclinação do fio de corte após o Ponto B } \\ \alpha & \end{array}$




$\begin{array}{ll}V_{f d} & \text { Fração de Volume dos "Debris" } \\ V_{f c o} & \text { Fração de Volume mínima do Abrasivo } \\ V_{f k o} & \text { Máxima fração de Volume do Corte da Cerâmica } \\ r & \text { Raio do Fio de Corte } \\ c & \text { Comprimento do Corte feito na Cerâmica } \\ \omega & \text { Ângulo de distribuição da Tensão na Cerâmica. } \\ \text { EDM } & \text { "Elecrical Discharge Machining" } \\ f_{n} & \text { Freqüência natural do tensionador } \\ \rho & \text { Densidade do aço } \\ f_{n f} & \text { Freqüência natural do fio de corte }\end{array}$




\section{SUMÁRIO}

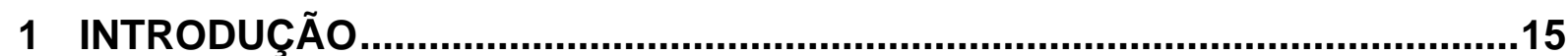

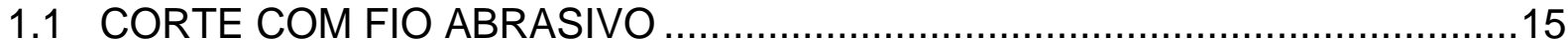

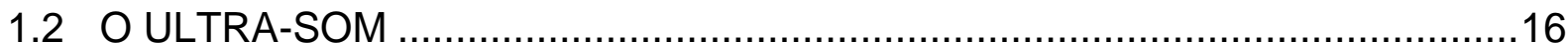

1.3 O PROCESSO DE CORTE POR FIO ABRASIVO NOS DIAS ATUAIS ............18

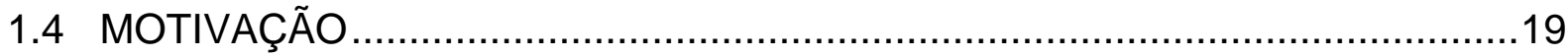

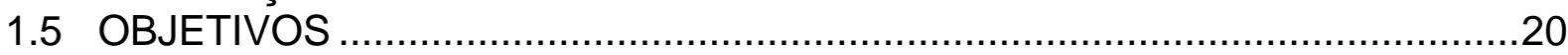

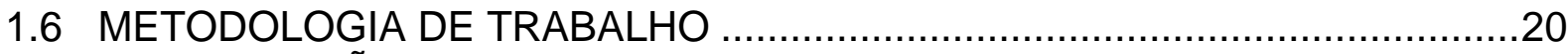

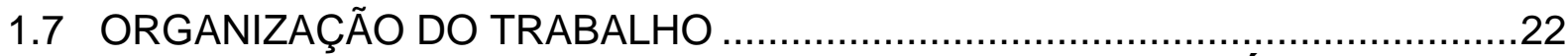

2 ASPECTOS CONSTRUTIVOS DE UM TRANSDUTOR PIEZELÉTRICO ..........24

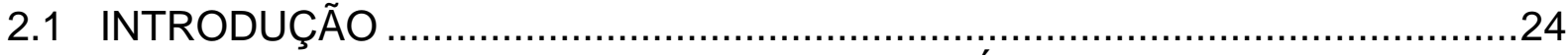

2.2 REQUISITOS DOS MATERIAIS PIEZELÉTRICOS UTILIZADOS EM

TRANSDUTORES DE ULTRA-SOM ..........................................................25

2.3 O USO DOS COMPÓSITOS EM TRANSDUTORES ULTRA-SÔNICOS .........27

2.4 CONFORMAÇÃO QUÍMICA X CONFORMAÇÃO MECÂNICA ........................28

2.5 COMO SE CORTAM MECANICAMENTE OS MATERIAIS CERÂMICOS PZT 29

2.6 MÉTODO DE FABRICAÇÃO "DICE AND FILL" .............................................30

2.7 ASPECTOS GERAIS NO CORTE DE CERÂMICAS …....................................

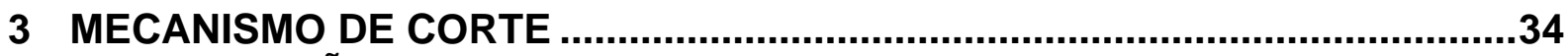

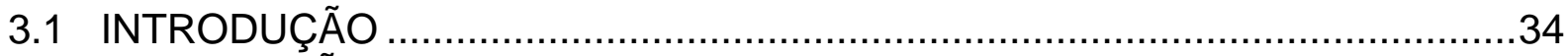

3.2 TRANSMISÃO DOS EIXOS HORIZONTAL E VERTICAL …..........................35

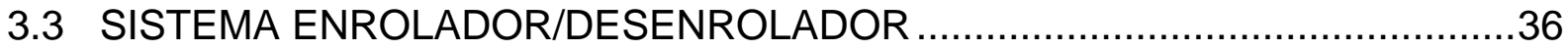

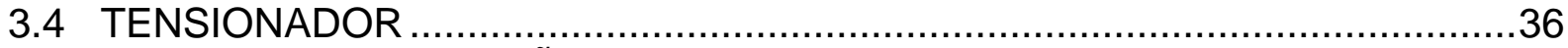

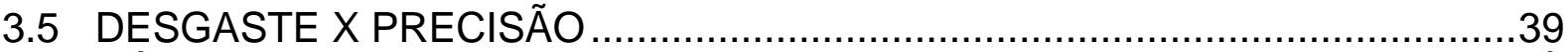

3.6 CÁLCULO DA FORÇA CORTANTE TRANSMITIDA PELO ABRASIVO À CERÂMICA $\quad 40$

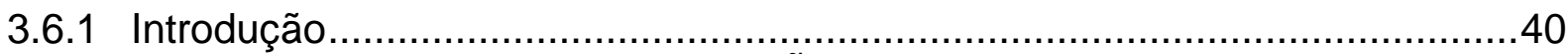

3.7 SISTEMA DE CONTROLE DE TENSÃO NO FIO …...............................43

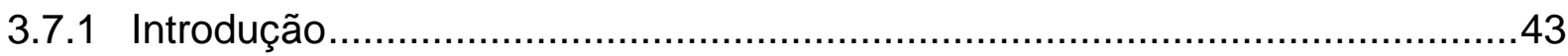

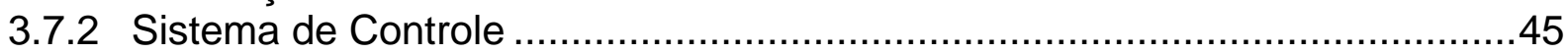

3.7.3 Implementação do Controle em Hardware ..............................................48

3.7.4 Cálculo da Resposta do Sensor de Tração ………..................................49

3.7.5 Análise da Ressonância do Fio de Corte..................................................50

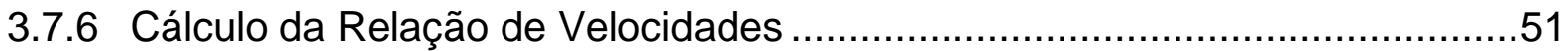

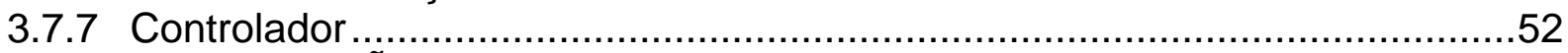

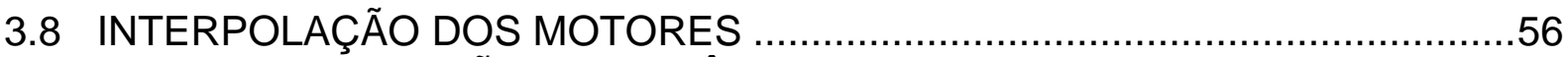

4 ESTUDO DA ABRASÃO DE CERÂMICAS ….........................................58

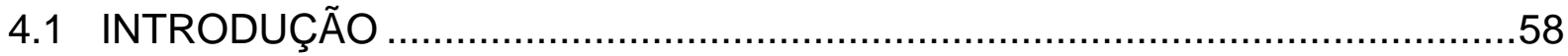

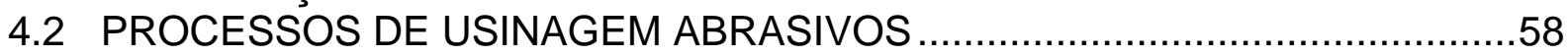

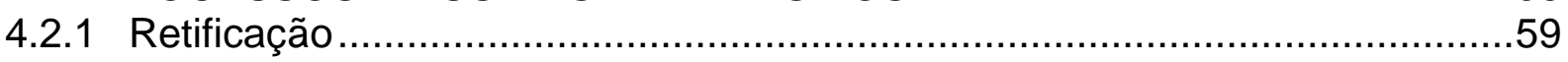

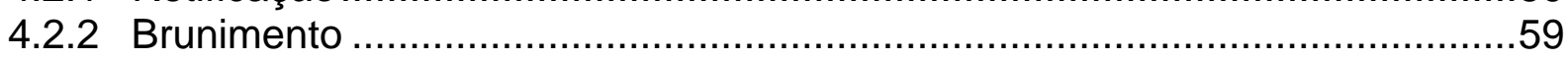

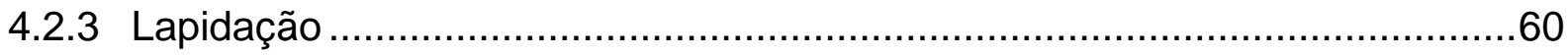

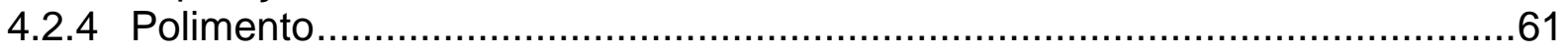

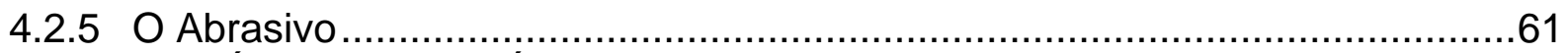

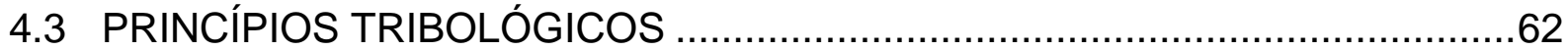

4.4 MECANISMOS DE DESGASTE DE MATERIAIS CERÂMICOS ......................63 


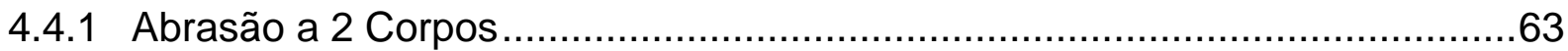

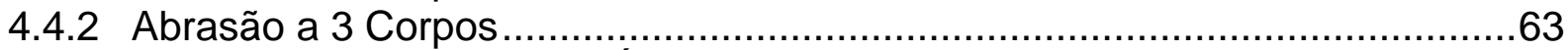

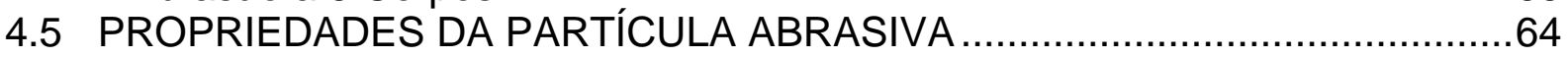

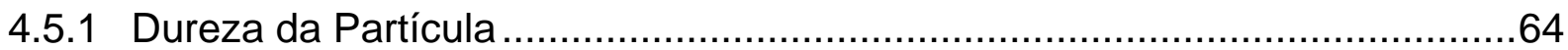

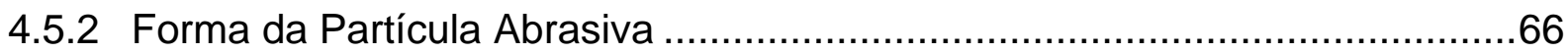

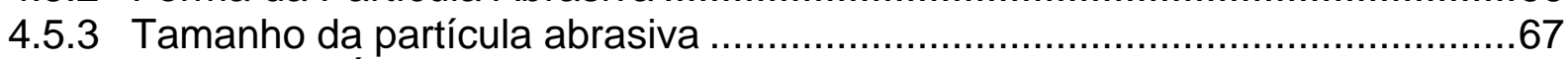

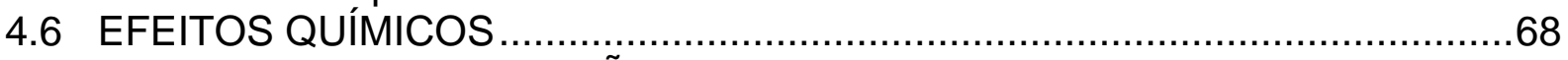

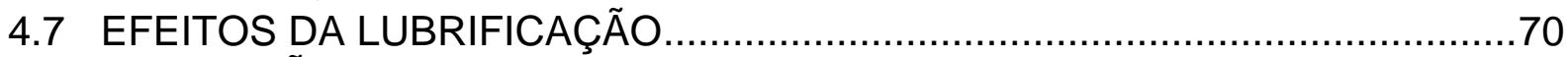

4.8 TRANSIÇÃO DO DESGASTTE BRANDO PARA O DESGASTE SEVERO .......71

4.9 PARÂMETROS DE USINAGEM ……................................................... 71

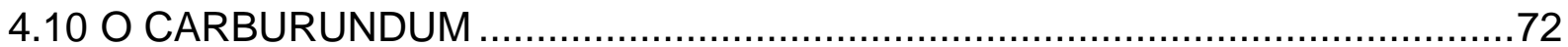

4.11 ESTIMATIVA DA TAXA DE DESGASTE NA USINAGEM POR ABRASÃO .....72

4.12 CONDIÇÕES PARA O CORTE NA INTERFACE …...................................73

4.13 Folga de corte entre o fio e a cerâmica ............................................................74

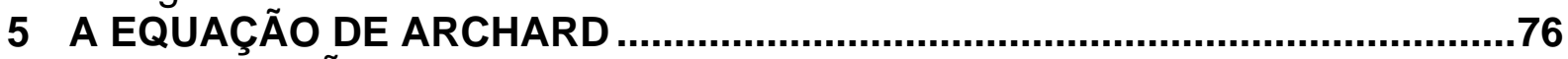

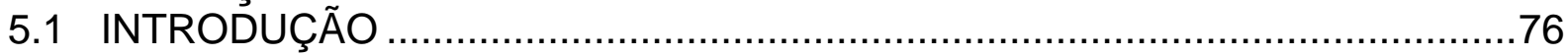

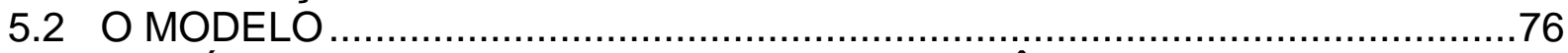

5.3 VARIÁVEIS QUE INFLUEM NO CORTE DA CERÂMICA ….........................79

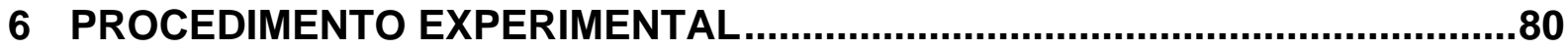

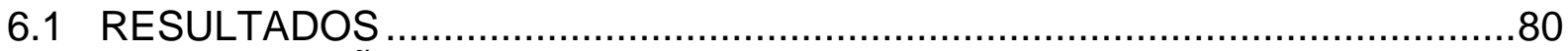

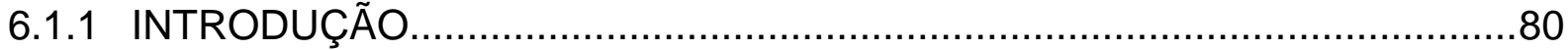

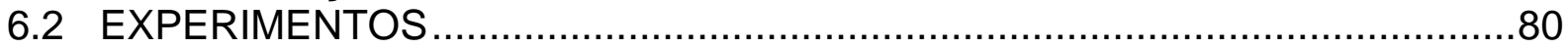

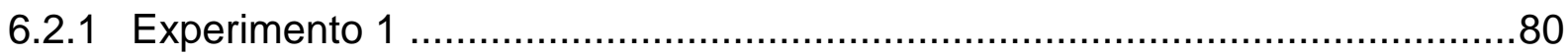

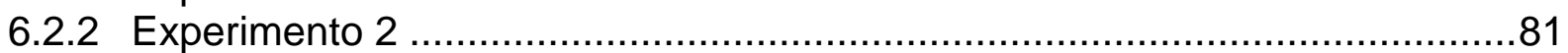

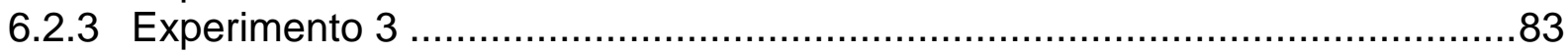

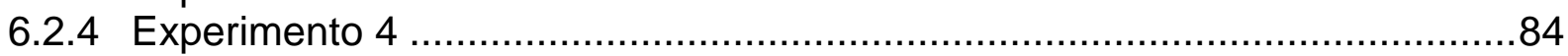

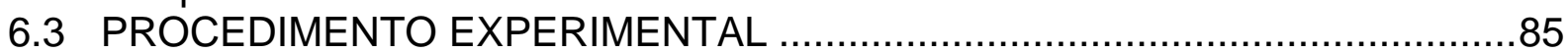

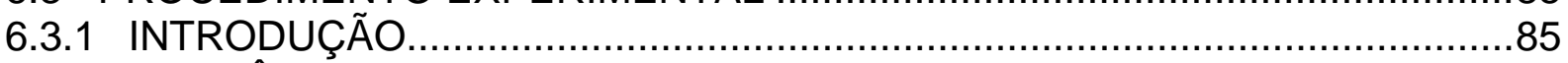

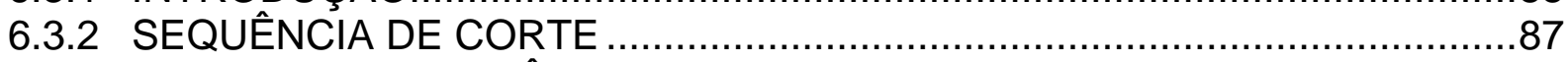

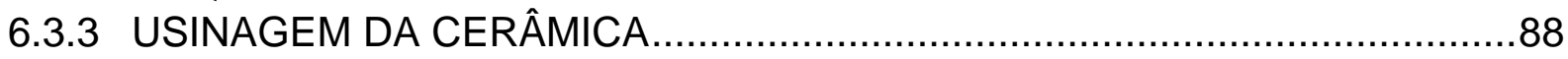

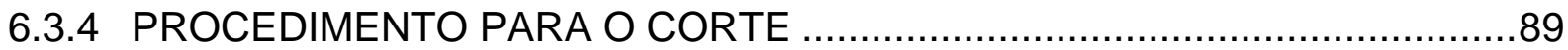

6.3.5 PRIMEIRO RESULTADO DO CORTE EXPERIMENTAL ..........................91

7 CONCLUSÕES E SUGESTÕES PARA TRABALHOS FUTUROS ....................92

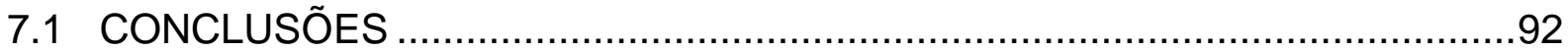

7.2 SUGESTÕES PARA TRABALHOS FUTUROS …...................................94

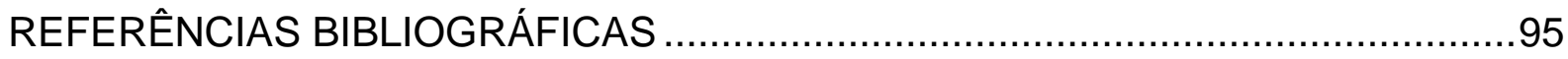




\section{INTRODUÇÃO}

\subsection{CORTE COM FIO ABRASIVO}

Cortar um cristal de silício em pequenas fatias conhecidas como "wafers", mantendose algumas propriedades tais como a estabilidade e espessura uniforme desse material sem ocorrer significativa perda de corte do elemento cortante, levou ao aumento do interesse em relação à tecnologia da usinagem através do corte por fio abrasivo.

As primeiras técnicas de corte com o uso de fio abrasivo para a criação dos "wafers" de silício, nasceram a partir de 1990, onde se utilizava um fio desprovido de qualquer elemento cortante. Uma pequena porção do elemento cortante era adicionada como um terceiro corpo entre a peça a ser trabalhada e o fio. Esse processo obteve êxito,no corte de silício e carbeto de silício como as matérias primas para a fabricação dos "wafers", utilizando-se diamante como abrasivo na interface entre o fio e o bloco de silício.

Comparado aos métodos principais de usinagem, o processo de usinagem por fio com abrasivo possui algumas vantagens. Primeiramente, esse método é capaz de usinar elementos que não sejam condutores elétricos e que por isso não são capazes de serem usinados pelo método de corte por eletroerosão (EDM). Além disso no método com fio abrasivo, pode-se projetar uma máquina de tal maneira, que um único fio faça vários cortes em paralelo em uma só operação. Outra grande vantagem desse método, é que ele mantém o corte do elemento cortante (resistência ao desgaste) um grau de magnitude superior se comparado ao corte do disco adiamantado.

A maior vantagem desse método, é que o fio de corte possui liberdade de movimento e orientação similares ao método EDM e se comparado às serras de corte circulares ou serras convencionais que não podem alterar suas direções de corte de maneira fácil. O método de corte com fio abrasivo é muito mais flexível em relação a usinar cortes com geometrias complicadas (CLARK et al.,2002). 
Uma outra aplicação desse método, é a confecção de trandutores piezocompósitos de ultra-som através da usinagem de canais em uma cerâmica piezelétrica. Essa aplicação é o alvo de estudo dessa dissertação de mestrado.

\subsection{O ULTRA-SOM}

Ultra-som é o nome dado às ondas sonoras que possuem freqüências maiores do que aquelas que o ouvido humano consegue detectar. Antes do começo do século $X X$ existiam poucos métodos para se gerar o ultra-som. O principal método consistia em um par de engrenagens que girava em alta velocidade e que assim excitava vibrações em folhas finas que eram pressionadas contra esse mecanismo, ou através de apitos com dimensões bem definidas. No entanto, ocorreram duas descobertas no século XIX que realmente foram de crucial importância para o futuro do desenvolvimento da tecnologia do ultra-som: A descoberta por J. P. Joule em 1847 da magnetostricção (mudança das dimensões exibida por materiais ferromagnéticos quando aplicado um campo magnético) e a descoberta do efeito piezelétrico pelos irmãos J. e P. Curie em 1880.

O desenvolvimento de aplicações submarinas para o ultra-som teve início durante a primeira guerra mundial, quando a ameaça que representavam os submarinos criou a necessidade da detecção de objetos submersos pelas forças aliadas o mais rápido possível.

Após fazer algumas experiências com transmissores de som eletrostáticos, $P$. Langevin construiu e demonstrou entre 1917 e 1918 diversos e poderosos transmissores piezelétricos de ultra-som. Para alimentar esses transmissores, geradores de freqüência com potência suficiente foram usados, e a construção deles só foi possível graças ao invento das válvulas eletrônicas. Assim, o cristal piezelétrico se firmou como sendo o principal meio de gerar ultra-som.

Após a primeira guerra mundial, quando o transmissor construído por Langevin não era mais tão necessário em aplicações militares, o desenvolvimento da tecnologia do ultra-som estagnou. No entanto, um evento em particular muito importante para a física acústica ocorreu em 1925 que foi a invenção do interferômetro ultra-sônico para gases, seguido pela invenção do interferômetro ultra-sônico para líquidos em 
1927 inventado por G. W. Pierce. Através desses equipamentos também foi descoberta a dispersão em dióxido de carbono como sendo um excelente absorvedor de ultra-som. Paralelamente a esse experimento, ocorreu também a exploração teórica da absorção do ultra-som através da relaxação térmica, estudada por Herzfeld e Rice em 1928 e em particular por Kneser em 1931.

O período correspondente a 1930 e ao começo da segunda guerra mundial foi caracterizado pela euforia em relação ao ponto de vista da aplicação intensa do ultra-som em várias áreas, desde o processamento de vidro até o processamento de alimentos. Até o corpo humano não foi deixado de fora, pois se acreditava que a cura de várias doenças através do uso do ultra-som era possível, no entanto muitas dessas aplicações não se mostraram úteis, pelo menos, não naquela época. Por outro lado a descoberta de Debye \& Sears, Lucas \& Biquard em 1932 da difração da luz por ondas de ultra-som pertence a esse período.

Após a segunda grande guerra, aconteceu um rápido desenvolvimento em todas as áreas relativas ao ultra-som. A pesquisa na física acústica atingiu seu pico inicial como conseqüência das melhorias das técnicas fundamentais de medição, graças ao grande desenvolvimento da eletrônica durante e após a guerra. Para a geração do ultra-som de alta intensidade, a descoberta e o desenvolvimento de materiais piezocerâmicos, como o titanato de bário e o titanato zirconato de chumbo (PZT), provaram ser especialmente importantes. Como conseqüência, a técnica piezelétrica da geração de ultra-som gradualmente ofuscou todas as outras técnicas, incluindo a técnica da transdução magnetostrictiva. Nesse período, muitas aplicações do uso intenso do ultra-som, em particular a limpeza através do ultra-som, chegaram à sua maturidade, levando assim a um entendimento mais profundo do fenômeno da cavitação. Em 1942, o método Pulso Eco foi inventado por Firestone e Sproule, que agora ajuda com sucesso o ensaio não destrutivo de materiais. Recentemente se popularizou o uso de transdutores compósitos, primeiramente em aplicações hidrostáticas, pois possuem alto coeficiente hidrostático de tensão e uma impedância acústica próxima a da água, mais tarde, descobriu-se a potencialidade do compósito cerâmico-polímero como um transdutor ultra-sônico de alta freqüência, que poderia ser utilizado em diagnósticos médicos através de imagens geradas por pulso-eco. 


\subsection{O PROCESSO DE CORTE POR FIO ABRASIVO NOS DIAS ATUAIS}

A vanguarda da tecnologia do processo de corte por fio abrasivo se encontra nos laboratórios de microeletrônica, onde é necessário fatiar blocos de silício com precisão para a produção de componentes eletrônicos. Para atender a essa indústria, foram desenvolvidos fios de corte, onde o abrasivo se encontra fixado rigidamente graças a um processo galvânico, onde uma camada de níquel é aplicada ao fio de aço sobre uma camada de diamante (GE,2004).

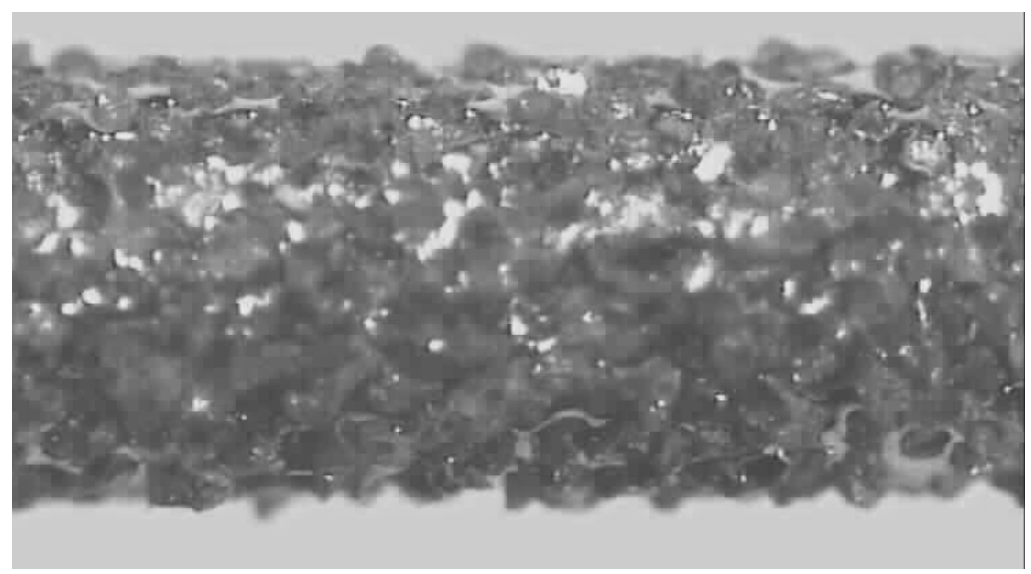

Figura 1.1 - Fio de corte adiamantado

As máquinas usadas na industria eletrônica, são capazes de realizar inúmeros cortes paralelos no silício simultaneamente, devido à resistência do fio de corte e a pouca perda de corte do mesmo durante o processo.

O avanço da eletrônica e dos sensores, permitiu a essas máquinas trabalharem a uma velocidade tangencial de corte de até 8 metros por segundo devido a ação dos sensores que monitoram a tensão do fio e a força exercida por esse fio sobre a peça a ser cortada ,evitando assim que esse fio se rompa. (WILLIAN, 2003) 


\subsection{MOTIVAÇÃO}

Os transdutores de ultra-som fabricados com piezocompósitos apresentam características de resposta em freqüência e de acoplamento com água que são importantes em aplicações de ensaios não destrutivos e na formação de imagens médicas. O método de fabricação do piezocompósito mais utilizado é o "Dice and Fill" que pode ser facilmente implementado a partir de cortes longitudinais e transversais em cerâmicas piezelétricas formando um reticulado em que as regiões dos cortes são fixadas com um polímero, como por exemplo, uma resina epóxi. Os cortes são geralmente executados com discos adiamantados girando em alta rotação. Esses dispositivos de corte utilizam "spindles" de alta rotação e baixa vibração que são compostos de componentes eletromecânicos de elevada precisão e portanto têm custo muito alto.

O Laboratório de Ultra-Som da Escola Politécnica da Universidade de São Paulo tem investido no estudo do corte de piezocerâmicas para a fabricação de piezocompósitos, tanto com disco adiamantado, quanto com fio abrasivo. O estudo do corte com fio abrasivo teve início com um trabalho de formatura do curso de graduação em Automação e Sistemas, em que o resultado foi um primeiro protótipo de uma máquina de corte de cerâmicas. Esse protótipo apresentou vários problemas de controle eletromecânicos o que não possibilitou o corte de cerâmicas. Considerando a necessidade desse tipo de corte e as dificuldades relacionadas ao entendimento do processo de corte e ao controle da máquina, foi iniciado este trabalho de mestrado. Além disso, o corte com disco adiamantado só permite cortes em linha reta e o processo de corte a fio permite cortes em várias direções. Essa característica pode ser explorada favoravelmente para a fabricação de piezoatuadores.

Esta dissertação se concentra no estudo de um tipo de corte muito específico de cerâmica, que é utilizado em uma das etapas da fabricação de transdutores piezelétricos de ultra-som por um método de fabricação conhecido como "Dice and Fill". No entanto, o estudo desse mecanismo de corte não deve ser descartado para a utilização também em outras aplicações, pois ele apresenta algumas vantagens interessantes, como por exemplo, a retirada de uma amostra de um determinado material sem ocorrer alteração no mesmo devido à elevação de temperatura. 


\subsection{OBJETIVOS}

O objetivo geral deste trabalho é estudar e desenvolver uma máquina de corte de cerâmicas piezelétricas utilizando a técnica de corte por fio abrasivo, incluindo o processo de monitoramento da tensão do fio de corte e o processamento dos sinais dos sensores envolvidos no monitoramento das variáveis envolvidas, bem como a aplicação real do corte em uma cerâmica piezelétrica. Já os objetivos específicos são: o estudo da fabricação de piezocompósitos pelo método "dice and fill"; estudo do desgaste dos materiais; a análise dos métodos de usinagem abrasivos; a escolha e a pesquisa das principais variáveis que influenciam a usinagem de cerâmicas pelo processo de corte por fio abrasivo; a escolha e o estudo do modelo de desgaste por abrasão que mais se aproxima do método de usinagem escolhido para a fabricação de cerâmicas piezocompósitos; a construção e o teste de um mecanismo automático de corte por abrasão, bem como o ajuste desse mecanismo para que ele trabalhe no seu melhor ponto de operação.

\subsection{METODOLOGIA DE TRABALHO}

A metodologia de trabalho para o estudo do tema desta dissertação de mestrado pode ser mais bem entendida pelo fluxograma da Figura 1.2.

De acordo com o fluxograma da Figura 1.2, a metodologia de trabalho pode ser explicada da seguinte forma:

- Estudo dos requisitos: Nessa etapa inicial são estudados os requisitos necessários à realização da usinagem da cerâmica através do processo de abrasão.

- $\quad$ Escolha do modelo de abrasão a ser utilizado: Após estudar a mecânica da abrasão, deve-se escolher um modelo que permita identificar e estudar as variáveis que são mais importantes na usinagem, e assim poder projetar um mecanismo de corte baseado na previsão do modelo.

- $\quad$ Estudo da mecânica da abrasão: Nessa segunda parte é essencial entender a mecânica do corte por abrasão e a partir daí projetar o mecanismo de corte da 
cerâmica baseado nas variáveis que mais influenciam na retirada de material da cerâmica.

- Projeto do mecanismo automático: Essa etapa consiste no projeto do mecanismo de corte em questão, levando-se em conta todas as variáveis importantes levantadas na parte anterior do estudo.

- Implementação do projeto: É a construção física do mecanismo de corte projetado.

- Testes comparativos: Após a construção do mecanismo de corte, devem ser comparados alguns dados fornecidos pela fórmula de Archard, e com isso tentar chegar aos parâmetros ótimos de corte respeitando os limites físicos impostos pelo mecanismo projetado ou pelo fio de corte. Para isso o mecanismo de corte foi testado em uma gama de regulagens e em diversas situações.

- Elaboração de procedimentos: Essa etapa consiste na elaboração de procedimentos para cortar corretamente o material através do método "Dice and Fill", utilizando o mecanismo de corte.

- $\quad$ Análise dos Resultados: Essa etapa consiste em verificar se os resultados estão de acordo com os resultados que eram esperados.

- Conclusão: É onde o mecanismo de corte é posto à prova, através da fabricação de uma cerâmica compósito utilizando todos os parâmetros préestabelecidos de corte das etapas anteriores dessa dissertação. 


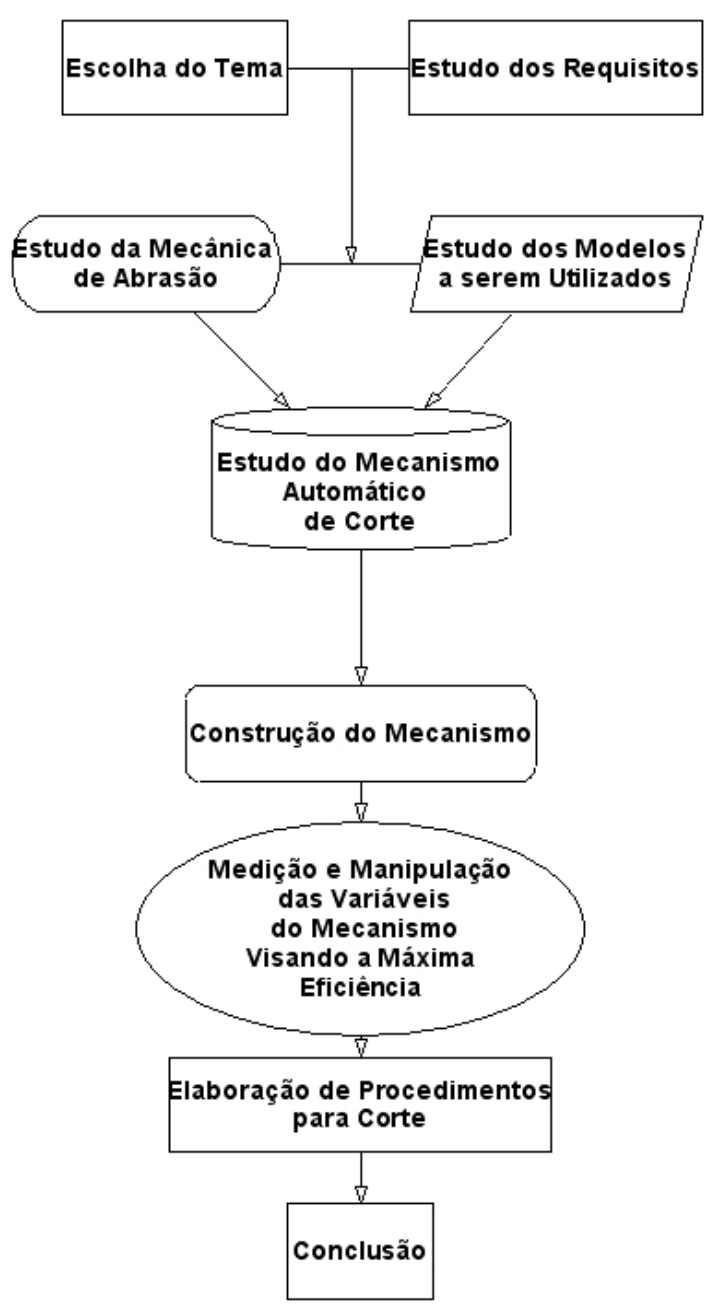

Figura 1.2 - Metodologia utilizada neste trabalho

\subsection{ORGANIZAÇÃO DO TRABALHO}

Neste item descreve-se a organização desta dissertação, que está dividida em 7 capítulos.

O Capítulo 1 é uma introdução aos processos de corte com fio abrasivo e a discussão sobre a história das invenções relativas ao desenvolvimento do ultra-som, as justificativas e os objetivos do trabalho, bem como foi organizada essa dissertação e quais sãos os objetivos da mesma, além de explanar a metodologia seguida.

O Capítulo 2 relata aspectos construtivos e de projeto de um transdutor piezelétrico. Mostra também como atualmente se cortam os materiais cerâmicos para a 
fabricação de transdutores de ultra-som e ainda descreve com detalhes o método de fabricação conhecido como "Dice and Fill".

O Capítulo 3 apresenta o mecanismo de corte propriamente dito, e descreve os detalhes do funcionamento do mesmo, qual a função e como funciona o sistema de controle de cada parte desse sistema mecatrônico.

O Capítulo 4 começa descrevendo as propriedades mecânicas do material cerâmico e algumas aplicações do mesmo. Este capítulo apresenta ainda a descrição e classificação de processos de usinagem que utilizam material abrasivo, e mostra que qualquer processo de usinagem abrasiva varia de quatro modos principais que são descritos neste mesmo capítulo. Além disso, são apresentados os dois principais tipos de abrasão, bem como uma breve descrição de variáveis que influenciam na abrasão, relacionando algumas propriedades da partícula abrasiva tais como: dureza da partícula, forma da partícula abrasiva, o tamanho do granulado do abrasivo, os efeitos triboquímicos que acontecem durante o corte. Além disso, ainda é descrito o que acontece em uma usinagem por abrasão com o uso de lubrificantes, a relação das variáveis que levam à transição do desgaste brando para o desgaste severo, bem como uma breve descrição das propriedades do carborundum que é o abrasivo utilizado no mecanismo de corte por abrasão deste trabalho.

O Capítulo 5 mostra como estimar a taxa de desgaste em um processo abrasivo através da fórmula de desgaste de Archard. Além disso, é mostrado como se chega a essa fórmula, quais as variáveis que a influenciam e como isso pode ser usado para se construir um mecanismo com o perfil exigido.

O Capítulo 6 registra uma experiência prática do uso do mecanismo de corte, e fornece técnicas e explicações de como conseguir um corte limpo e alinhado no objeto a ser cortado. Este capitulo também mostra os gráficos comparativos para regulagem do mecanismo de corte. Foram testados diversos regimes de funcionamento e foram tecidos comentários sobre o porquê ou não da escolha do valor de um determinado parâmetro.

O Capítulo 7 apresenta as conclusões desta dissertação bem como sugestões para continuar o estudo da técnica de corte com fio abrasivo. 


\section{ASPECTOS CONSTRUTIVOS DE UM TRANSDUTOR PIEZELÉTRICO}

\subsection{INTRODUÇÃO}

O principal elemento de um transdutor é a cerâmica piezelétrica (SHIKATA, 1997). A maioria dos transdutores é classificada em dois grupos: transdutores de banda larga e de banda estreita. Os transdutores de banda estreita são usados nas aplicações de alta intensidade, onde as baixas freqüências (20 a $100 \mathrm{kHz}$ ) são predominantes. Já os transdutores de banda larga operam em freqüências maiores, na faixa de 0,5 a $50 \mathrm{MHz}$, gerando pulsos de ultra-som estreitos.

As cerâmicas piezelétricas que fazem parte de transdutores que operam com pulsos devem ter alto fator de acoplamento eletromecânico, impedância acústica adequada, impedância elétrica que pode ser facilmente casada a circuitos eletrônicos, e boa estabilidade em relação ao tempo e à temperatura desses materiais.

A estrutura básica de um transdutor construído para obter respostas impulsivas ótimas consiste, essencialmente, em um disco de cerâmica piezelétrica, vibrando no seu modo de espessura, tendo uma camada de retaguarda em uma de suas faces e uma camada de casamento na outra, como pode ser visto na Figura 2.1.

A camada de retaguarda é feita de um material de alta atenuação e impedância acústica semelhante ao do elemento piezelétrico. O efeito da retaguarda é o amortecimento da vibração mecânica, aumentando a transferência de energia acústica para o meio de propagação e aumentando-se, assim, a largura da banda.

Os materiais para a retaguarda e a camada de casamento de impedâncias são geralmente misturas de epóxi e pó de metais pesados que são selecionados com base nas suas impedâncias acústicas e coeficientes de atenuação (BLITZ, 1967), (SMITH,1989).

Na cerâmica estão depositados, em cada uma de suas faces, os eletrodos que consistem em um filme metálico de prata, cromo e níquel. 


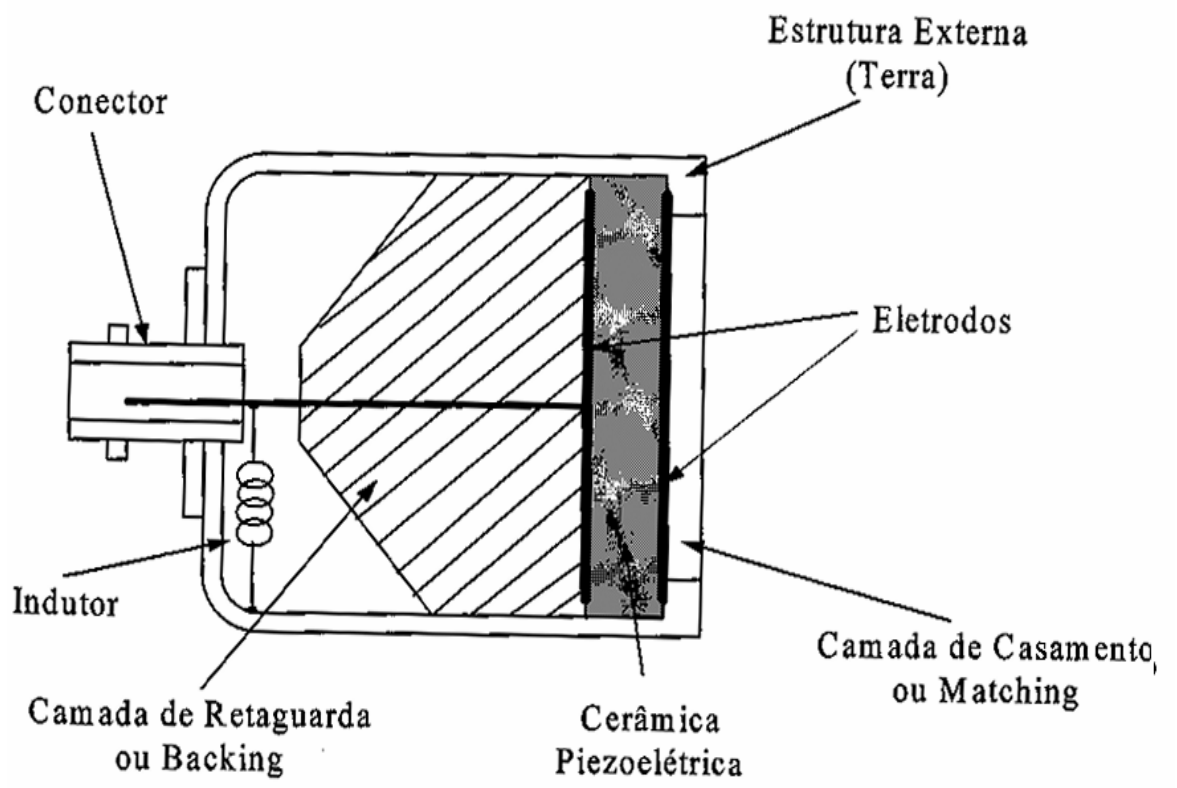

Figura 2.1 - Esquema de um transdutor piezelétrico

\subsection{REQUISITOS DOS MATERIAIS PIEZELÉTRICOS UTILIZADOS EM TRANSDUTORES DE ULTRA-SOM}

Um dos fatores relacionados à sensibilidade de um transdutor de ultra-som é o coeficiente de acoplamento eletromecânico do modo de espessura do material piezelétrico, representado por $K_{t}$. Esse coeficiente de acoplamento eletromecânico do modo de espessura é geralmente definido como a raiz quadrada do quociente entre a energia elétrica ou mecânica armazenada no material e a energia fornecida ao material por uma fonte energética externa. $O$ fator $K_{t}$ não pode ser confundido com eficiência, pois ele não está relacionado às perdas em um processo. Ele apenas indica a capacidade de um material piezelétrico armazenar e transformar uma forma de energia em outra, elétrica em mecânica ou vice-versa. Em princípio, uma parte da energia que não é convertida permanece no material em sua forma inicial podendo até mesmo ser recuperada. A eficiência é, então, a razão entre a potência utilizada na saída e a potência disponível na entrada.

Além da vibração no modo de espessura, os materiais piezelétricos em forma de disco fino apresentam um outro tipo de vibração conhecido como modo radial ou planar. Essa vibração em modo planar interfere na vibração em modo de espessura, 
dificultando o aumento da banda do transdutor em aplicações acústicas pulso-eco. É sempre desejável ter um fator de acoplamento grande no modo de espessura e um fator bem pequeno nos modos planares. Obter um fator de acoplamento planar, $K_{p}$, pequeno evita a interferência desses dois modos de vibrar em uma mesma freqüência. Em relação aos compósitos, os modos laterais surgem da periodicidade dos pilares de cerâmica que vibram fora de fase na matriz de polímero. Para suprimir essa interferência, procura-se fazer uma amostra onde a altura do pilar seja pelo menos duas vezes a largura do mesmo.

O material piezelétrico deve ter sua impedância acústica casada com a impedância do meio em que se pretende propagar, a fim de que as ondas acústicas do transdutor e o do meio se acoplem bem durante a transmissão e recepção, diminuindo, assim, as perdas relativas à reflexão na interface do transdutor com o meio de recepção.

Além disso, existem algumas propriedades elétricas e mecânicas importantes do elemento que deverão ser compatíveis com os dispositivos de geração e recepção do sinal.

Os fatores $Q_{e}$ e $Q_{m}$, conhecidos respectivamente, por fator de qualidade elétrica e fator de qualidade mecânica, computam as perdas e determinam a eficiência e a largura de banda de um determinado transdutor.

$\mathrm{Na}$ maioria dos casos as perdas mecânicas são mais relevantes do que as perdas elétricas para as cerâmicas, mas de qualquer maneira, é fundamental que os fatores de qualidade elétrica e mecânica sejam pequenos, menores que 0,1 no caso do fator de qualidade elétrico e da ordem de 10 no caso do fator de qualidade mecânico (KUTTRUFF, 1991), para se obter um transdutor de banda larga.

Para que uma largura de banda do transdutor seja estreita, deseja-se um valor alto de $Q_{m}$ e como conseqüência o tamanho do pulso emitido pelo transdutor é longo. Valores de $Q_{m}$ baixos indicam a capacidade de o transdutor gerar um pulso curto e possuir uma largura de banda grande. Um fator $Q_{m}$ baixo, não apenas está relacionado às perdas, mas principalmente a uma boa transferência da energia acústica dentro do material, o que indica um excelente acoplamento da impedância do transdutor com o material do meio exterior. A impedância do material se torna, então, outro fator essencial na largura de banda do transdutor (GALLEGO-JUÁREZ, 1989). 
Para aumentar a largura de banda do transdutor são usados basicamente dois processos. Um dos métodos consiste em amortecer mecanicamente a ressonância através de uma camada de retaguarda acoplada ao meio piezelétrico, assim boa parte da energia é transmitida para dentro do material da camada de retaguarda resultando em uma baixa sensibilidade. O outro método consiste em transmitir mais energia para o meio através de uma camada de acoplamento de impedância, a qual

possui $1 / 4$ de espessura do comprimento de onda e a impedância característica igual à média geométrica da impedância acústica da cerâmica piezelétrica do transdutor e do meio (BRIZOTTI, 2006).

Com o acoplamento acústico otimizado e dependendo dos quesitos de sensibilidade, largura de banda e resposta impulsiva, essa impedância acoplada varia de 4 a 7 MRayls. Uma vez que não existe nenhum material puro conhecido que possua esse valor é preciso preparar um material para atender essa demanda e tal tarefa não é nada fácil. Mais recentemente o compósito surgiu como uma nova e promissora alternativa na obtenção de valores práticos de impedância acústica e tem ajudado a aumentar a largura de banda do transdutor (BRIZOTTI, 2006).

Os compósitos mantêm baixos os fatores de qualidade mecânico e elétrico, diminuem os modos planares e aumentam o acoplamento eletromecânico $K_{t}$. Por todos esses fatos, fica claro que os piezocompósitos possuem características superiores às piezocerâmicas e piezopolímeros individualmente, como são discutidos em alguns trabalhos (GURURAJA et al.,1985) e (PAPADAKIS et al., 1999).

\subsection{O USO DOS COMPÓSITOS EM TRANSDUTORES ULTRA-SÔNICOS}

Uma infinidade de materiais piezelétricos pode ser obtida combinando-se de maneiras diferentes uma ou mais fases individuais de materiais puros. A finalidade dessa combinação é obter o melhor das propriedades individuais de cada elemento em um só elemento combinado. A esse novo elemento dá-se o nome de compósito, e mais especificamente dá-se o nome ao material piezelétrico compósito de piezocompósito (PAPADAKIS et al., 1999). 
A conectividade, que é definida como sendo o número de direções em que cada fase é continua, é um conceito utilizado para classificar um piezocompósito, já que ele é geralmente composto por duas fases distintas. A conectividade é representada por dois números que são separados por um traço. O primeiro representa a conectividade da cerâmica piezelétrica e o segundo representa a conectividade do polímero. Os compósitos mais comuns são os com conectividade 0-3, 1-3 e 2-2. O compósito 2-2, que é tratado mais especificamente nesta dissertação, consiste de seqüência alternada de pilares: um pilar de polímero seguido por um pilar de cerâmica. Os compósitos bifásicos formados por uma cerâmica piezelétrica ativa e um polímero inerte são materiais nos quais a cerâmica produz o efeito piezelétrico e o polímero reduz a densidade e a permissividade elétrica de tal maneira que essas propriedades dependam somente da fração volumétrica de polímero e dos materiais que constituem cada fase e do modo como são interconectadas as fases individuais (GALLEGO-JUÁREZ, 1989).

Existem muitos métodos de fabricação de materiais piezelétricos compósitos. Os compósitos 0-3 geralmente são construídos misturando-se polímero (PAPADAKIS et al., 1999). Após a cura do mesmo, o compósito é aquecido sob um campo elétrico, da ordem de kV/mm, para polarizar as partículas de material piezelétrico. Para se construir compósitos com conectividade 1-3 e 2-2 em larga escala, é utilizado moldagem por injeção (PAZOL et al., 1995). Nesse processo é misturado adesivo com pó de material piezelétrico e em seguida essa mistura é colocada em um molde. Após a secagem, o material é retirado do molde e é colocado em um processo de sinterização. Após esse processo os vãos do material são preenchidos com um polímero. A última etapa consiste em lapidar o material para então polarizá-lo. Existe também o método de fabricação "Dice and Fill" para a fabricação de compósitos com conectividade 1-3 e 2-2 que é tratado na seção 2.6

\subsection{CONFORMAÇÃO QUÍMICA X CONFORMAÇÃO MECÂNICA}

As chamadas técnicas não abrasivas, que utilizam as energias termoelétricas e químicas, tais como a usinagem a laser, têm oferecido um acabamento superior do que as técnicas que utilizam energia mecânica. No entanto, sua capacidade de 
remoção de material ainda é muito baixa e o custo de capital na aquisição dos equipamentos ainda é um obstáculo. Essas máquinas são muito sofisticadas e quase não são usadas na prática.

A conformação das cerâmicas pelos processos que utilizam energia mecânica ainda é a forma mais aceita e a mais usada pela indústria. Dentre os processos de conformação que utilizam energia mecânica, o processo de usinagem por abrasão é o mais popular. Isso se deve em grande parte por causa do custo do processo, que é o mais barato. As máquinas empregadas no processo de conformação mecânica estão disponíveis em uma grande variedade de tipos e formas. Essas máquinas têm conseguido atender a quase todas as aplicações na fabricação de peças em cerâmica que são usadas em componentes avançados.

Outra vantagem está no fato de que o processo consegue remover uma quantidade superior de material e com maior velocidade, em comparação aos processos não abrasivos e menos convencionais.

A produtividade também é um fator importante na escolha de um processo específico.

É possível encontrar na literatura muitos tipos de técnicas usadas na conformação das cerâmicas entre elas: extrusão, injeção, corte com disco adiamantado, corte com fio abrasivo, etc.

A técnica mais usada no corte de cerâmicas piezelétricas (comumente chamada de PZT), na fabricação de compósitos 1-3 e 2-2, é a mesma usada pela indústria microeletrônica na separação de componentes e cortes em substratos para a fabricação de microcomponentes pela indústria de semicondutores, que é o corte através do disco adiamantado. (EFRAT, 1993); (GATZEN, 2001); (JIANG; SONG; ZHANG, 2003).

\subsection{COMO SE CORTAM MECANICAMENTE OS MATERIAIS CERÂMICOS PZT}

O tipo de corte que é alvo deste estudo é muito específico. Para isso, atualmente, é usado um disco de corte adiamantado que possui uma espessura da ordem de centésimos de milímetro em contraste com o seu diâmetro externo da ordem de 50 $\mathrm{mm}$. Isso faz com que esse disco seja demasiadamente frágil e necessite de uma 
máquina com um projeto baseado em princípios de mecânica de precisão, pois qualquer vibração, pode fazer com que esse disco de corte seja destruído. Esse método de corte de cerâmica para fabricação de transdutores piezelétricos é muito eficiente, porém necessita de peças frágeis que possuem um custo muito alto (disco de corte e máquina de usinagem) e sofrem desgaste, ou seja, algumas peças caras precisam ser freqüentemente trocadas. Para grandes produções, é também viável fazer os cortes na cerâmica piezelétrica usando corte a laser, pois a utilização do laser (BRIZOTTI, 2006) permite a criação de pequenos espaçamentos entre as barras de material cerâmico, porém esse é um processo também muito caro. Uma outra técnica que tem sido estudada para o corte de cerâmicas é o corte com fio abrasivo, no entanto, esse método tem a desvantagem de fornecer baixas taxas de remoção de material se comparado ao método do disco adiamantado. Esse método é tratado com detalhes no próximo capítulo.

\subsection{MÉTODO DE FABRICAÇÃO “DICE AND FILL”}

Um dos métodos de fabricação mais utilizados para a construção de materiais piezelétricos compósitos em pequena escala é o processo "Dice and Fill" (SAVAKUS et al.,1981), (BRIZOTTI,2006).

Nesse processo, é utilizado um mecanismo de corte para usinar canais na cerâmica piezelétrica. Primeiramente são feitos cortes paralelos em uma determinada direção. Depois a cerâmica é girada de $90^{\circ}$, e são feitos mais cortes paralelos. Note que a cerâmica não é atravessada totalmente pelo corte no plano vertical, como pode ser visto na Figura 2.2. 


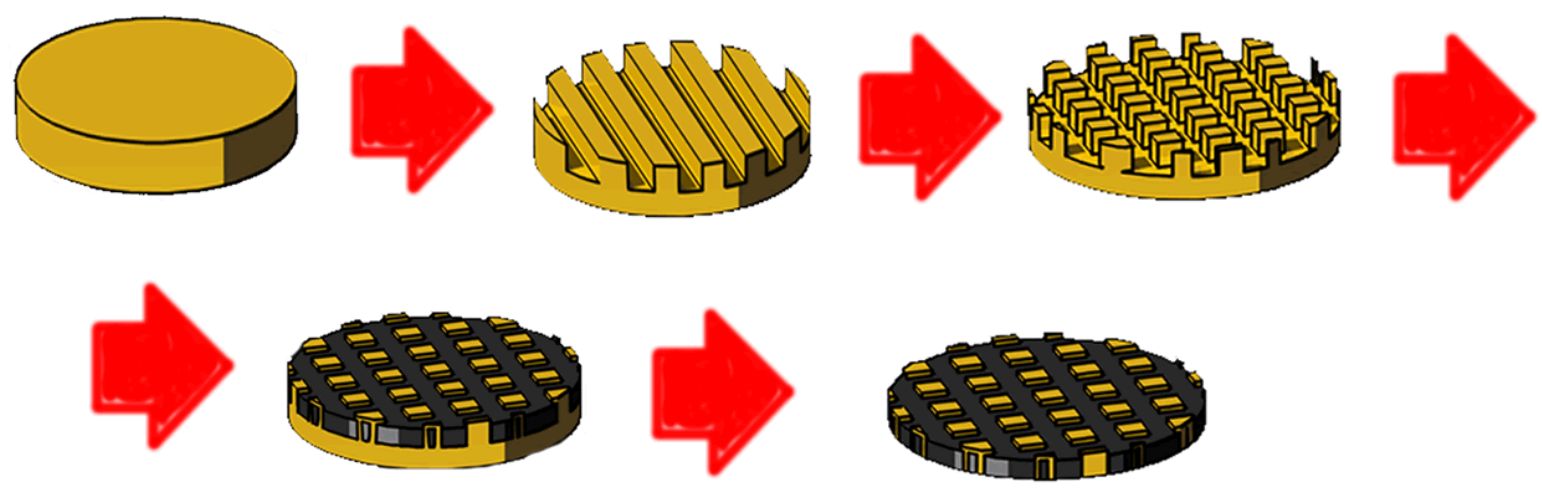

Figura 2.2- Método "Dice and Fill"

Após a realização dos cortes é acrescentado um polímero sobre os canais. Após a cura do polímero, tem-se uma sustentação para que se possa retirar a parte que dava sustentação a cerâmica através de outro processo de usinagem chamado retificação.

O resultado desse método de fabricação pode ser visto na Figura 2.3.

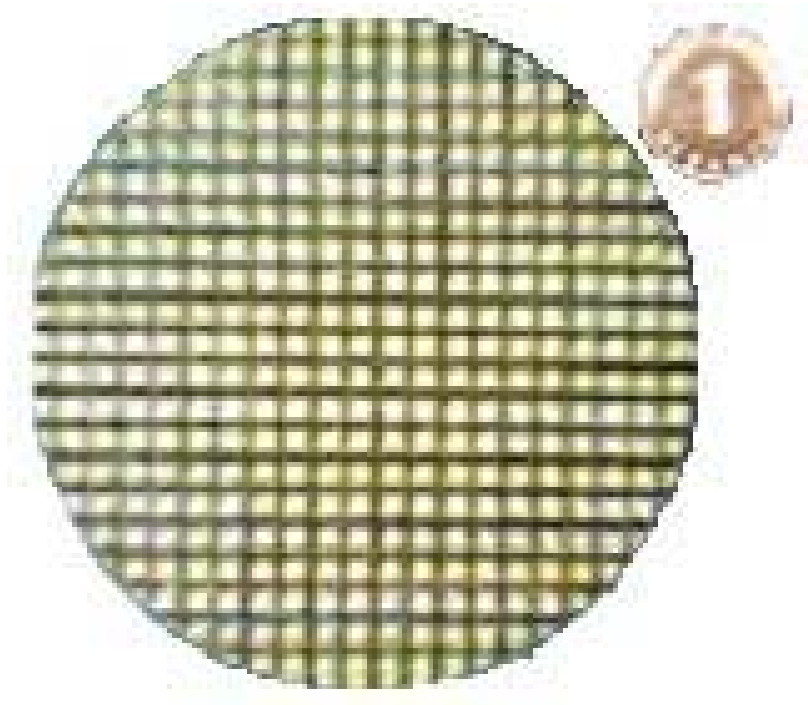

Figura 2.3 - Resultado do método "Dice and Fill"

\subsection{ASPECTOS GERAIS NO CORTE DE CERÂMICAS}

O processo de fabricação de compósitos 1-3 e 2-2 pelo método "Dice and Fill" é feito através da conformação mecânica do bloco monolítico pelo processo de desgaste 
da cerâmica por fio abrasivo. As propriedades elétricas e mecânicas são prioridades para os fabricantes quando comparadas às propriedades que facilitariam a usinagem por abrasão, como por exemplo, o tamanho do grão e a pureza do material. A qualidade da cerâmica está relacionada diretamente em manter as propriedades piezelétricas da mesma e não a de garantir a usinabilidade da mesma. Por esse motivo, o material geralmente apresenta uma estrutura granulada que pode conter um número relativamente alto de defeitos que levam a peça final a ter alguns defeitos na usinagem. O grande problema disso é que ao perder um número de pilares ocorrerá uma redução considerável na sensibilidade do transdutor podendo chegar até a inviabilizar o uso do mesmo, (DUNLAP JR., 2004).

Segundo Takeuchi (1997) essa limitação na conformação mecânica do bloco monolítico se deve em grande parte ao tamanho de grão do PZT, na ordem de micrometro podendo alcançar até décimos de micrometro.

Um outro fator importante é usinar as cerâmicas de forma a desacoplar os modos laterais dos modos de espessura.

A Figura 2.4 apresenta as curvas de módulo e fase da impedância de um disco de cerâmica piezelétrica PZT5A. Verifica-se que há uma forte interferência dos modos planares no primeiro modo de vibração de espessura.

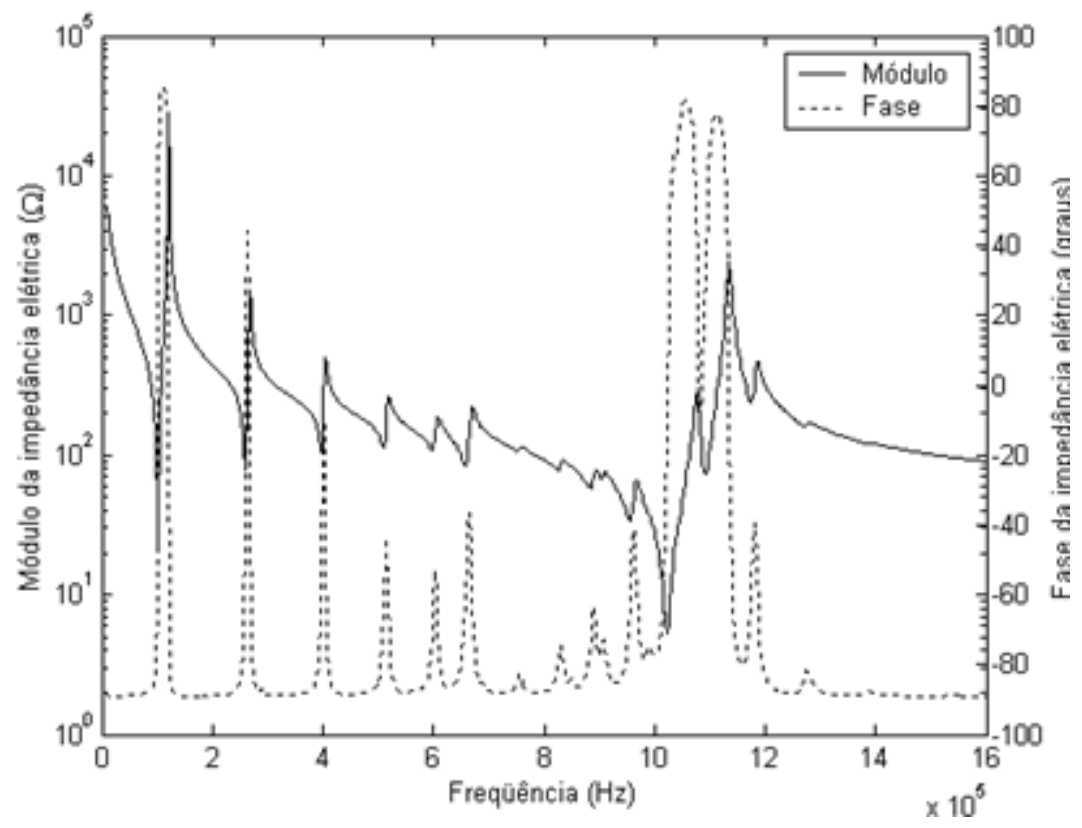

Figura 2.4 - Impedância elétrica de um disco de cerâmica de $20 \mathrm{~mm}$ de diâmetro e $2 \mathrm{~mm}$ de espessura 
Já na Figura 2.5 pode ser visto o gráfico da resposta em freqüência onde apenas o modo de espessura aparece, que é a situação desejada.

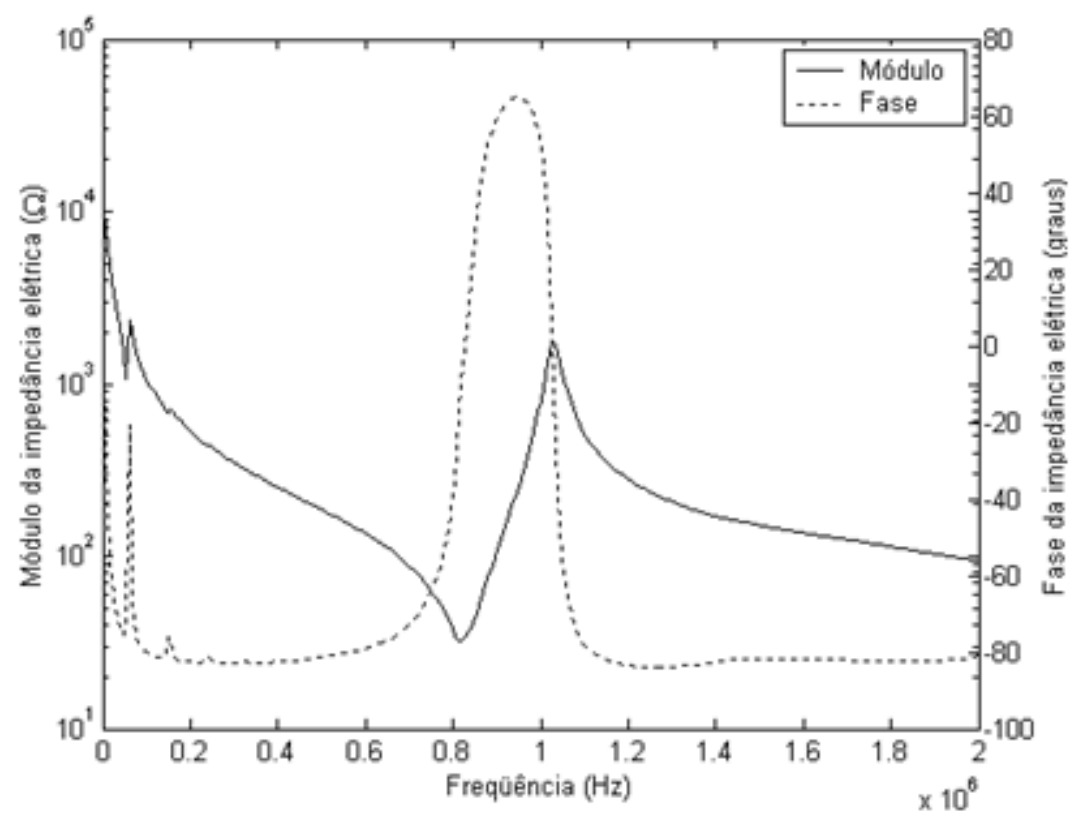

Figura 2.5 - Impedância elétrica de um material compósito 1-3 de 20 mm de diâmetro e 1,854 $\mathrm{mm}$ de espessura

Para atingir essa situação desejada é recomendável obedecer a relação de usinagem, descrita pela equação (1) e mostrado na Figura 2.6, sendo B é a medida correspondente a profundidade de corte e $\mathrm{V}$ é a medida do topo de um pilar do piezocompósito.

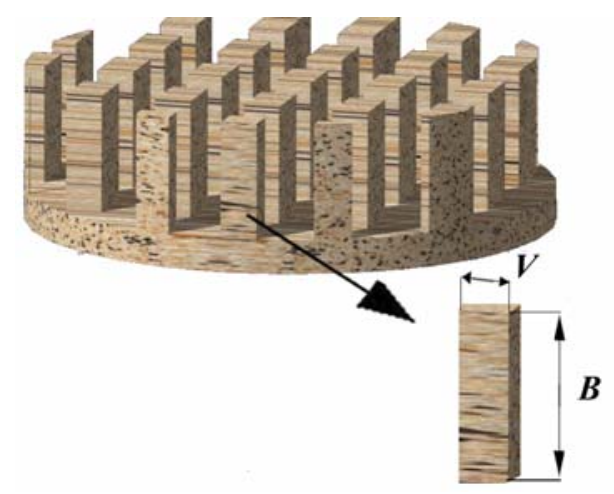

Figura 2.6 - Relação geométrica dos cortes da cerâmica 


\section{MECANISMO DE CORTE}

\subsection{INTRODUÇÃO}

O mecanismo automático de corte proposto utiliza um método de corte muito simples, que é o método de corte por desgaste por abrasão. O mecanismo de corte é composto por um fio metálico ao qual é impregnado partículas abrasivas chamada carborundum. Ao fio é dado um movimento relativo a peça de trabalho sendo o fio atritado contra o material cerâmico, como mostra a Figura 3.1. Este movimento é repetido várias vezes até se formar um canal no formato do fio, com uma determinada profundidade de corte que se deseja em uma cerâmica piezelétrica. A máquina ainda possui as seguintes regulagens:

- $\quad$ velocidade tangencial do fio;

- $\quad$ regulagem da força normal aplicada à cerâmica pelo fio;

- $\quad$ passo dos cortes;

- $\quad$ profundidade de corte;

- $\quad$ tensão aplicada ao fio. 


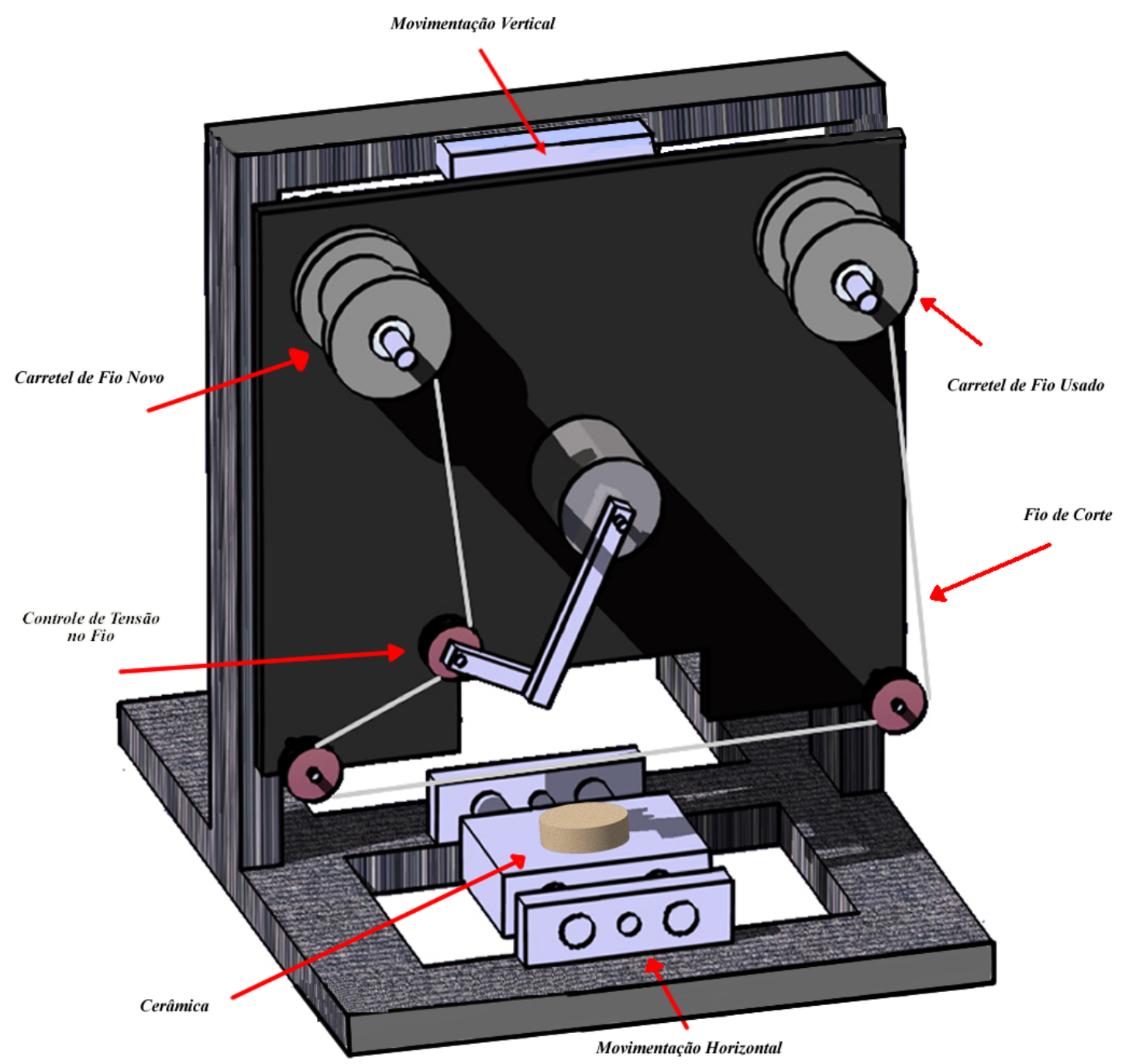

Figura 3.1 - Esquema da máquina

\subsection{TRANSMISÃO DOS EIXOS HORIZONTAL E VERTICAL}

Os elementos utilizados para posicionar a cerâmica nos eixos verticais e horizontais são duas guias lineares com fuso de esferas recirculantes, com um passo de $3 \mathrm{~mm}$ e precisão de aproximadamente 0,05 mm. Acoplando-se um motor de passo a esse fuso acionado em meio passo (400 posições por volta), tem-se uma resolução de $0,0075 \mathrm{~mm}$ em cada eixo. 


\subsection{SISTEMA ENROLADOR/DESENROLADOR}

O sistema que enrola e desenrola o fio de corte é composto por um motor de passo ligado ao carretel que desenrola o fio, um outro motor de passo ligado ao carretel que enrola o fio, um mecanismo tensionador que possui um sinal de realimentação analógico e mais duas polias que servem de guia. A máquina é programada para manter a tensão no fio sempre constante. Então, quando ocorre o avanço do fio de corte, as velocidades dos motores são controladas para que a tensão tenha uma variação máxima de $15 \%$. Esse valor foi estimado a fim de minimizar o deslocamento angular do mecanismo que exerce a tração no fio, pois valores maiores fariam com que o contra-peso realizasse deslocamentos grandes. A velocidade de avanço do fio pode ser regulada para que o mesmo passe diversas vezes sobre a cerâmica antes de ser inutilizado.

\subsection{TENSIONADOR}

Um ponto importante do mecanismo de corte está baseado na tensão do fio, pois um fio com uma tensão muito baixa, não irá realizar o corte na cerâmica. No entanto um fio com uma tensão muito alta, pode causar o seu rompimento. Assim uma máquina para cortar cerâmicas por abrasão com o mecanismo de corte proposto, tem a tensão no fio variando a todo o momento, já que as forças envolvidas variam. Para isso, foi proposto e construído um tensionador em malha fechada, ou seja, esse tensionador, através de um sensor resistivo e um conversor analógico digital, é capaz de medir o ângulo A, mostrado na Figura 3.2. Dependendo do valor do ângulo, os motores de passo responsáveis pela liberação e recolhimento do fio, ajustam automaticamente a tensão no mesmo. O fio usado no mecanismo possui uma força de ruptura de $1,85 \pm 0,05 \mathrm{kgf}$ medido por uma máquina de tração Megor modelo $143 \mathrm{H}$. 


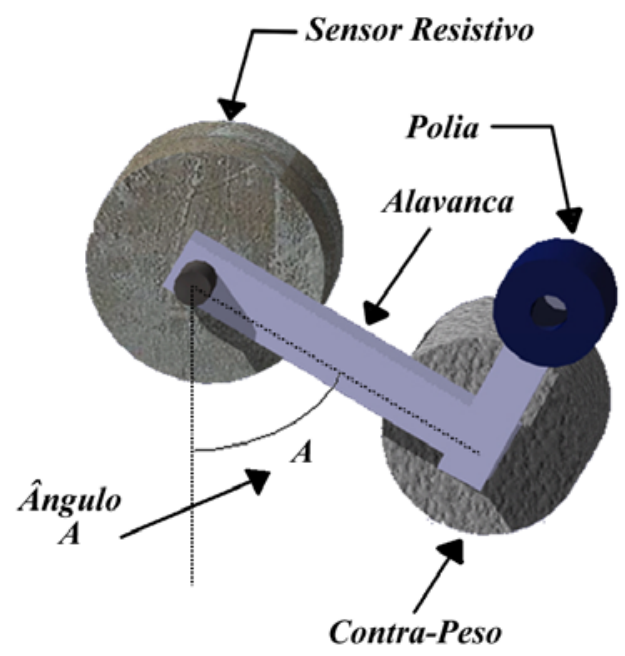

Figura 3.2 - Tensionador com sensor resistivo

O sinal analógico do tensionador é recebido por um conversor analógico digital com resolução de 8 bits, ou seja, consegue distinguir 256 diferentes níveis de tensão. 0 sensor utilizado tem um curso útil de $90^{\circ}$, ou seja, o sistema tem a capacidade de medir um deslocamento em graus de aproximadamente $0,36^{\circ}$.

Com base na região elástica do fio de aço inox, é possível determinar as regiões (ângulos) ideais para o funcionamento da máquina. O sensor possui uma pequena força elástica de torção contrária ao movimento, que é desprezível em relação às forças envolvidas no sistema. Supondo que a polia acoplada ao sensor esteja em repouso, é possível fazer o cálculo da eq. (2) para determinar a variação de tensão no fio, como visto na Figura 3.3:

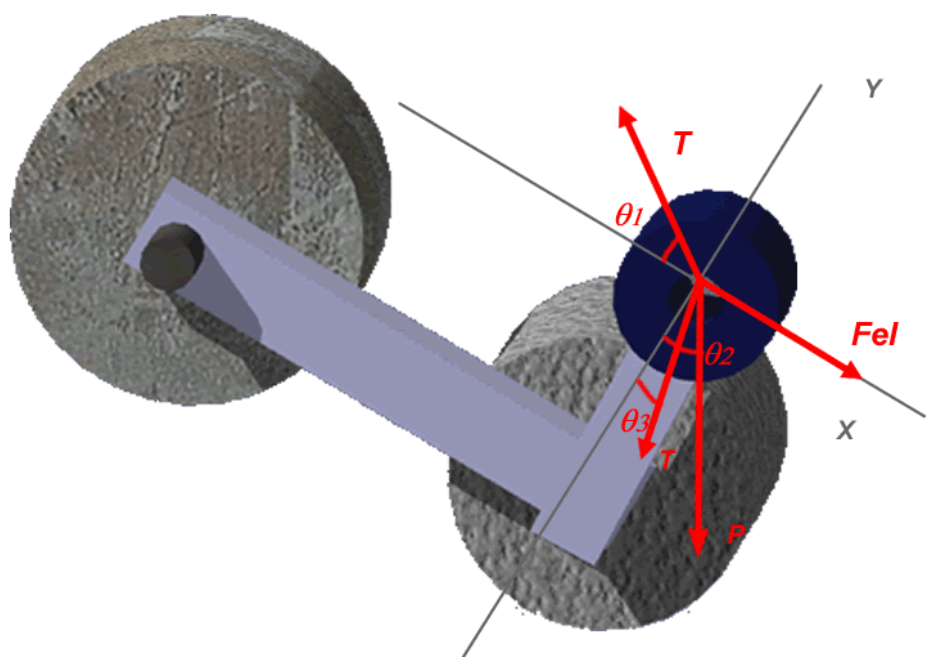

Figura 3.3 - Equilíbrio na polia tensionadora 
Fazendo o Equilíbrio de forças no centro da polia e desconsiderando a força elástica obtém-se:

$$
T=\frac{P \cdot \operatorname{sen} \theta_{2}}{\cos \theta_{1}-\operatorname{sen} \theta_{3}}
$$

Levantando-se um gráfico da força pelo deslocamento angular do eixo do sensor, Figura 3.4 , verifica-se que em um ângulo de $40^{\circ}$, a tensão no fio atinge a tensão de ruptura do mesmo. Esse será considerado o limite máximo de tensão aplicada ao fio, porém como medida de segurança a região onde preferencialmente a máquina deverá trabalhar é a de $\mathrm{A}=30^{\circ}$.

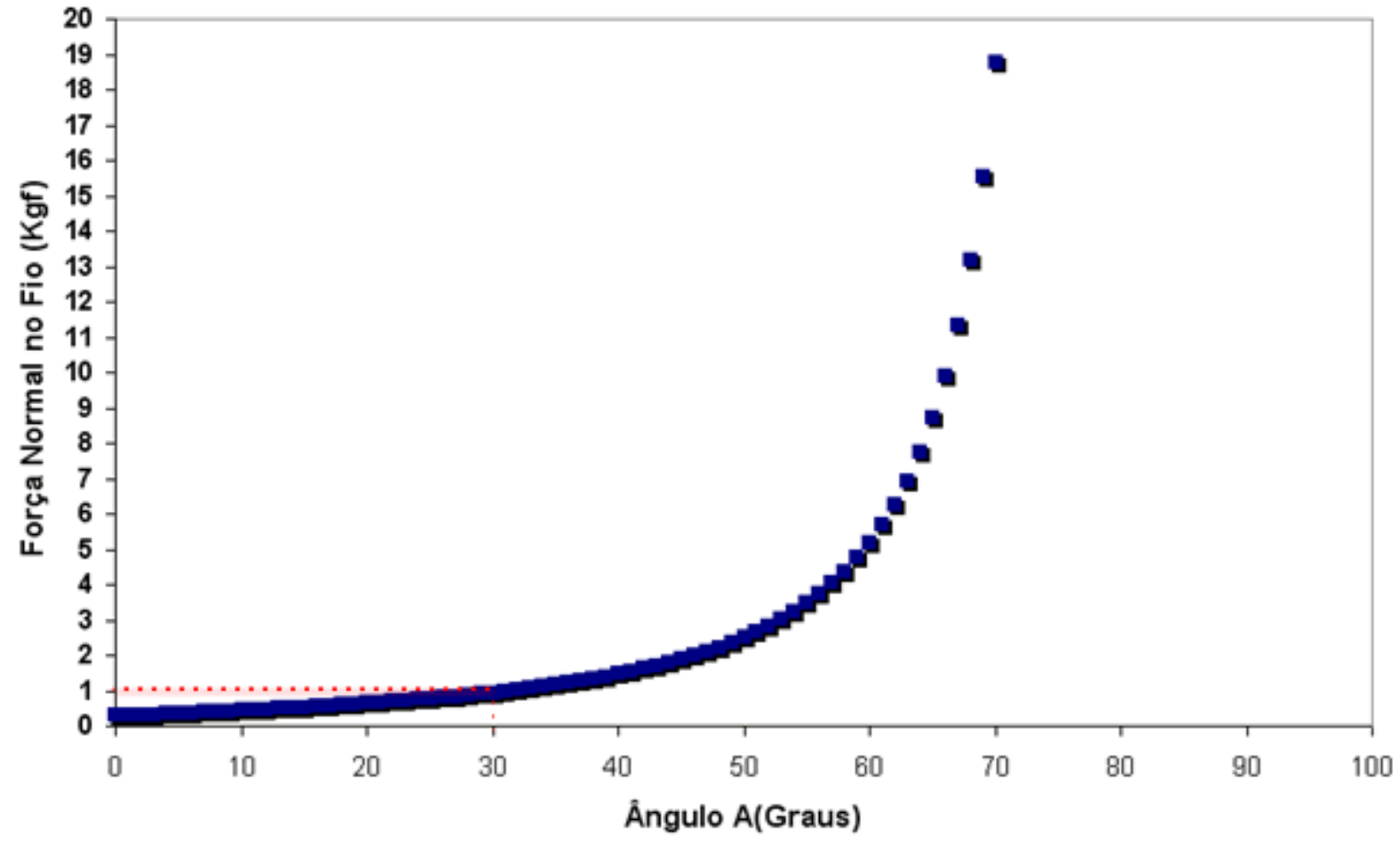

Figura 3.4 - Relação ângulo x força normal no fio 


\subsection{DESGASTE X PRECISÃO}

Um dos elementos mais críticos ao se projetar uma máquina de usinagem é como: maximizar a taxa de desgaste da peça a ser usinada, diminuir a taxa de desgaste dos componentes inerentes ao funcionamento da mesma e ainda manter a precisão requerida.

Em uma máquina de corte a fio, manter essas condições é ainda mais complicado, pois o fio possui baixa rigidez. Para criar uma maior rigidez na região de corte é necessário acrescentar um guia para o fio, o qual passa também a sofrer desgaste, comprometendo assim a precisão de posicionamento do fio. As máquinas industriais que utilizam fio de corte, normalmente utilizam guias de diamante, safira ou metal duro.

As guias utilizadas inicialmente na máquina foram feitas de aço temperado com dureza superior a $60 \mathrm{HRc}$ e, em menos de seis horas de trabalho, o desgaste nelas foi evidente, como é visto na Figura 3.5, o que comprometeu seriamente a qualidade dos primeiros ensaios.

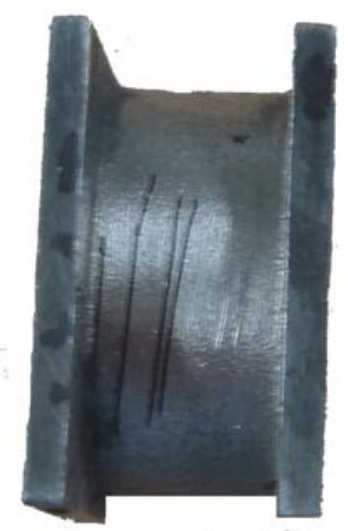

Figura 3.5- Guia com desgaste

A solução encontrada para o problema foi substituir as guias de aço temperado por guias apropriadas de safira utilizados em máquinas de eletro-erosão a fio. 


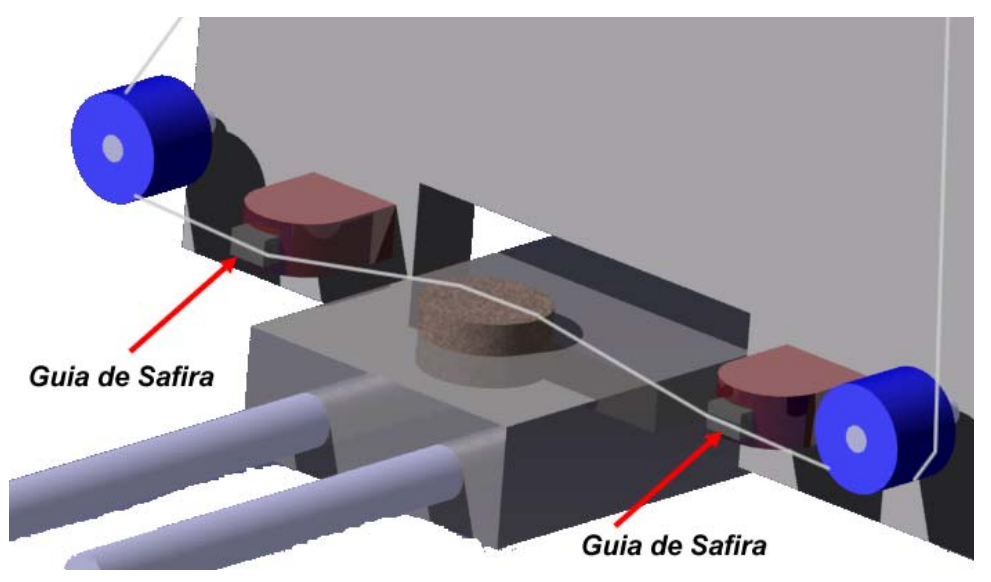

Figura 3.6- Posicionamento das guias na máquina

\subsection{CÁlCULO DA FORÇA CORTANTE TRANSMITIDA PELO ABRASIVO À CERÂMICA}

\subsubsection{Introdução}

Uma das variáveis mais importantes para a usinagem da cerâmica é a força cortante que é transmitida pelo fio à cerâmica através do contato entre o fio e o abrasivo na interface. Como pode ser visto na Figura 3.7, existe uma dependência entre essa força cortante $F_{V}$ a força normal $F_{H}$ e a inclinação do fio.

Assumindo que o corte ocorra em uma área muito estreita que pode ser simplificada como se fosse um ponto de contato. Como pode ser visto na figura 3.7, quatro forças interagem no ponto $\mathrm{B}$ onde ocorre o corte. As forças $F_{H}$ e $F_{V}$ são as forças horizontal e vertical respectivamente e existem também duas forças de tração $T_{1}$ e $T_{2}$ agindo em sentido opostos. É sabido ainda que $\psi_{1}=\theta_{1}+\alpha$ e $\psi_{2}=\theta_{1}+\alpha$. $\theta_{1}$ e $\theta_{2}$ são os ângulos de inclinação do fio dos dois lados (WILLIAM I. C et al, 2003). 


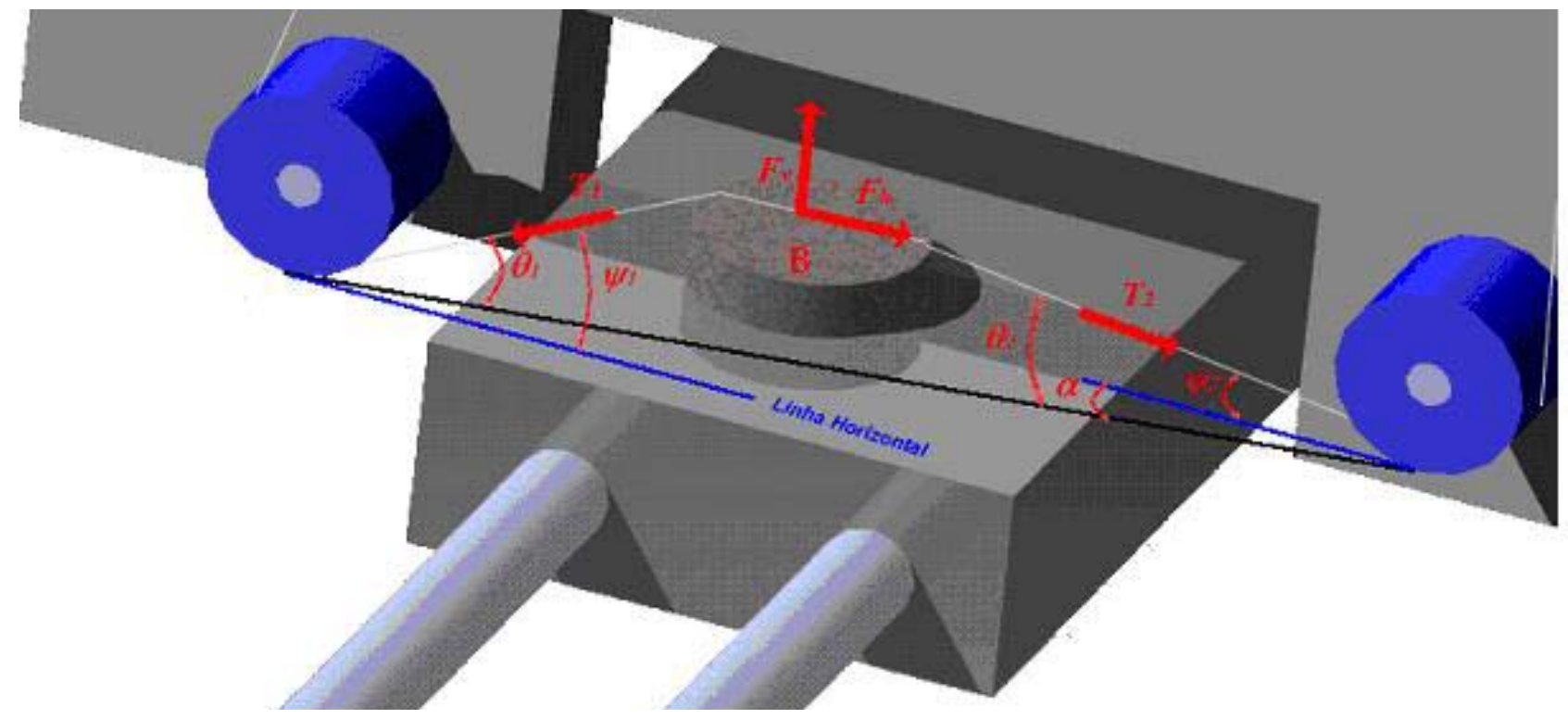

Figura 3.7 - Balanço de Forças na Região de Corte

O balanço de forças no ponto B pode ser escrito como:

$$
\begin{aligned}
& \sum F_{x}=F_{H}-T_{2} \cos \psi_{2}+T_{1} \cos \psi_{1}=0 \\
& \sum F_{y}=F_{V}-T_{2} \operatorname{sen} \psi_{2}-T_{1} \operatorname{sen} \psi_{1}=0
\end{aligned}
$$

Das 6 variáveis das equações (3) e (4), duas podem ser medidas, $\psi_{1}$ e $\psi_{2}$, então isolando $T_{1}$ e $T_{2}$ tem - se:

$$
\begin{aligned}
& T_{1}=\frac{-F_{H} \operatorname{sen} \psi_{2}+F_{V} \cos \psi_{2}}{\cos \psi_{1} \operatorname{sen} \psi_{2}+\cos \psi_{2} \operatorname{sen} \psi_{1}} \\
& T_{2}=\frac{F_{H} \operatorname{sen} \psi_{2}+F_{V} \cos \psi_{2}}{\cos \psi_{1} \operatorname{sen} \psi_{2}+\cos \psi_{2} \operatorname{sen} \psi_{1}}
\end{aligned}
$$


No entanto, quando o ponto B está exatamente no meio do segmento entre as duas polias, e as polias se encontram alinhadas com o eixo horizontal, é necessário apenas de um sensor para medir a tensão do fio, como é demonstrado a seguir:

$$
\begin{aligned}
& \psi_{1}=\psi_{2}=\theta_{1}=\theta_{2}=\psi \\
& \alpha=0
\end{aligned}
$$

Como o produto $F_{H} \operatorname{sen} \psi$ é muito menor que o produto $F_{V} \cos \psi$, já que $\psi$ é suficientemente pequeno, então:

$$
T=\frac{F_{V} \cos \psi}{\cos \psi \operatorname{sen} \psi+\cos \psi \operatorname{sen} \psi}
$$

Então a força vertical pode ser escrita por:

$$
F_{V}=2 \cdot T \cdot \operatorname{sen} \psi
$$

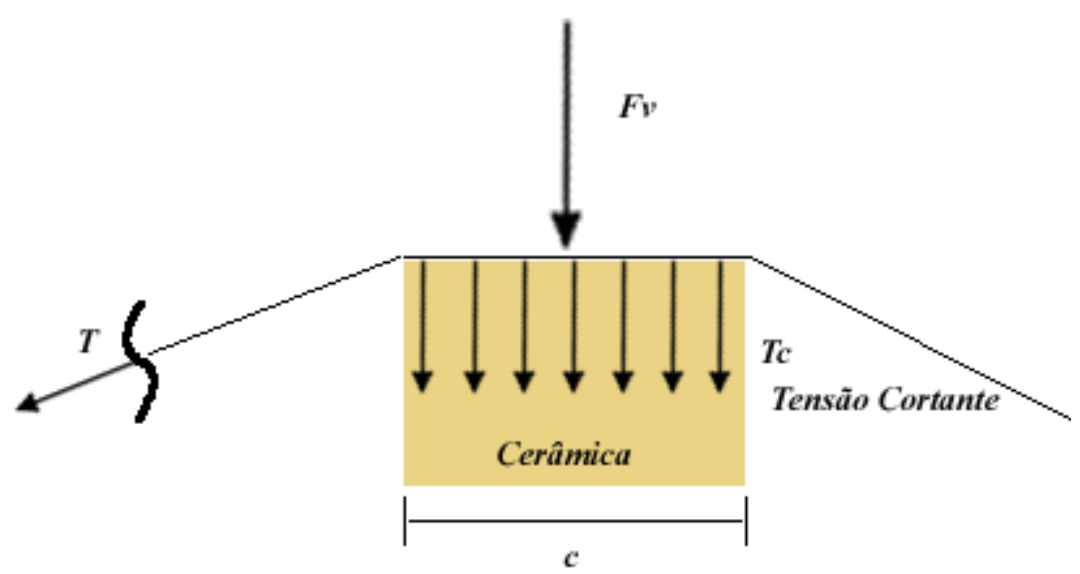

Figura 3.8 - Conversão de tensão normal em tensão cortante

$$
T c=\frac{F_{v}}{A f}
$$


onde

$$
A f=\pi \cdot r . c
$$

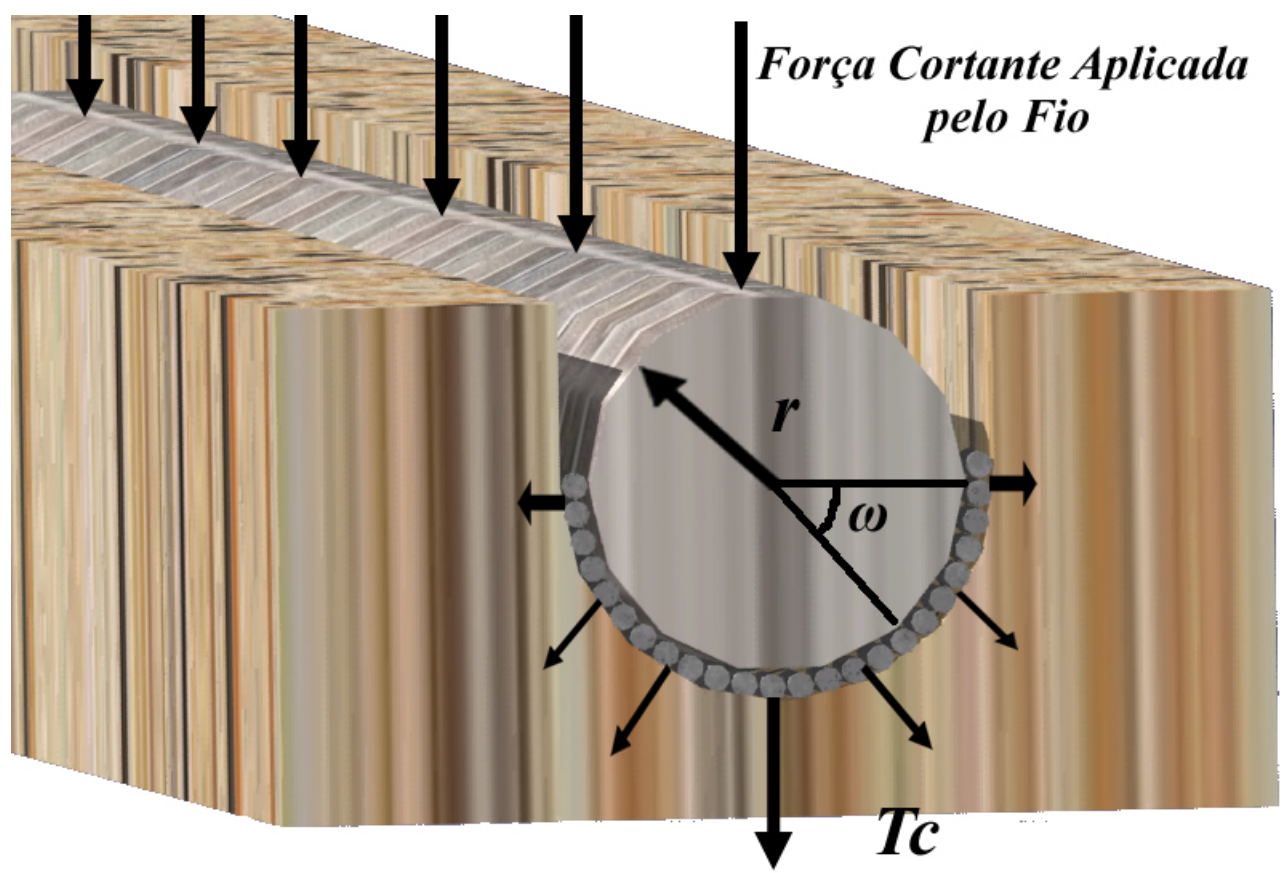

Força Transmitida Pelo Abrasivo

Figura 3.9-Distribuição de tensão na interface cerâmica e abrasivo

Como pode ser visto na Figura 3.9, a tensão transmitida pelo fio à interface entre o abrasivo e a cerâmica obedece a seguinte formulação:

$$
\operatorname{Tc}(\omega)=\operatorname{Tc} \cdot \operatorname{sen}(\omega)
$$

\subsection{SISTEMA DE CONTROLE DE TENSÃO NO FIO}

\subsubsection{Introdução}

Para manter um nível de tensão no fio com variação máxima de $15 \%$ é necessário um sistema de controle de tensão. O controle de tensão possibilita o aumento da 
velocidade de corte devido a diminuição da vibração do fio. Existe uma região onde não há mais a tração no fio de corte, e por isso, ele fica emaranhado em cima do corpo a ser cortado como pode ser visto na Figura 3.11. Por isso é muito importante utilizar um controlador que consiga evitar essa região para que o fio fique tensionado obtendo-se assim o comportamento desejado como pode ser visto na Figura 3.10.

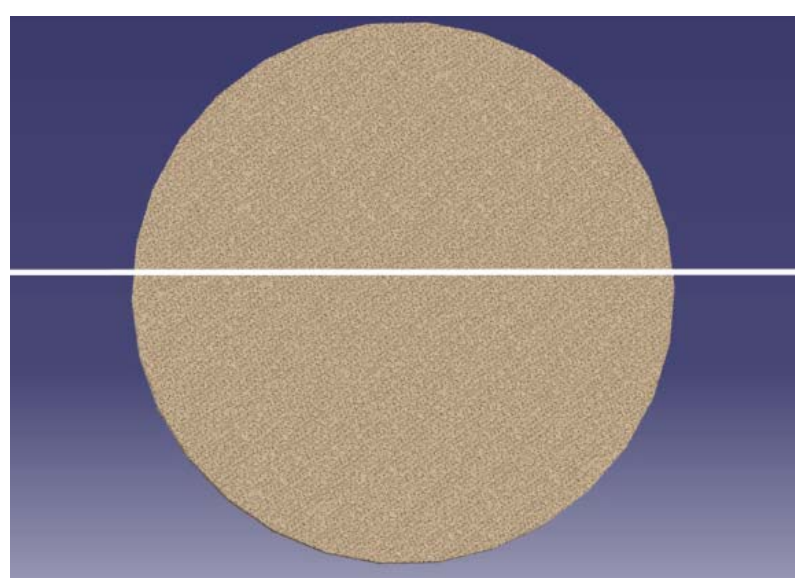

Figura 3.10 - Fio de corte corretamente tensionado

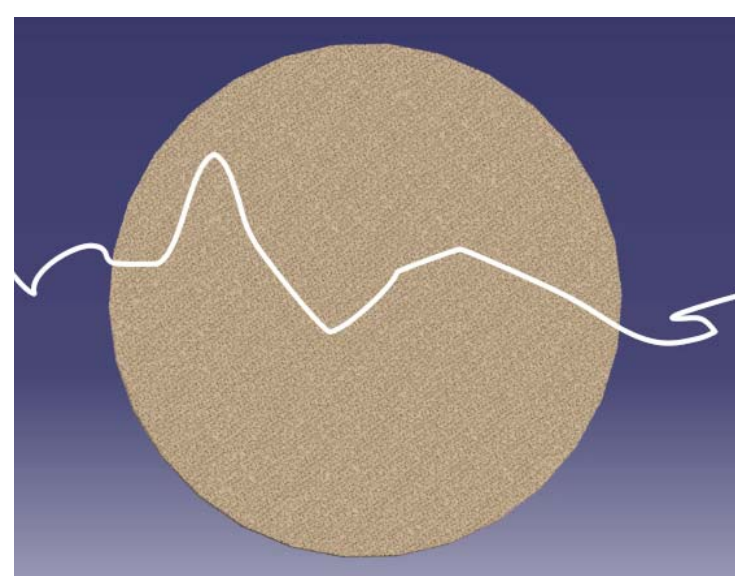

Figura 3.11 - Fio de corte não tensionado 


\subsubsection{Sistema de Controle}

Para escolher qual tipo de controlador é o mais adequado para o sistema que se deseja controlar, primeiramente é necessário obter a função de transferência desse sistema, para depois determinar qual tipo de controlador a ser utilizado.

Para isso é usada a seguinte equação:

$$
\tau_{\text {res }}=I . \ddot{\theta}
$$

onde $\tau_{\text {res }}$ é a resultante dos momentos aplicados ao sistema e $I$ é o momento de inércia em relação ao eixo de rotação.

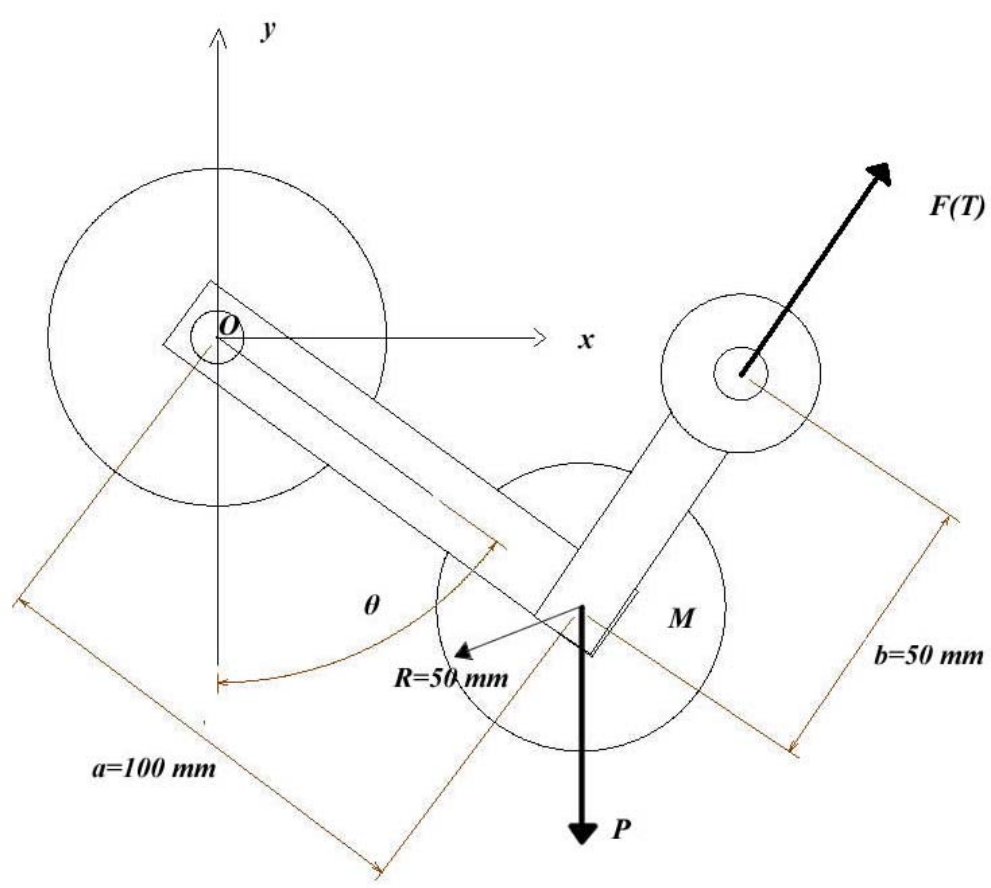

Figura 3.12-Sistema Mecânico do Sensor

O momento de Inércia do sistema mostrado na Figura 3.12 em relação ao pólo O é calculado da seguinte maneira (foram desprezados os momentos de inércia dos braços de alumínio de comprimento $a$ e $b$, por serem muito mais baixos que o da massa $M$ ): 


$$
I=\frac{1}{2} M \cdot R^{2}+M \cdot a^{2}
$$

onde $M$ é a massa do contra-peso, $R$ é o raio do contra-peso e $a$ é a distância entre o baricentro do contra-peso e o pólo $\mathrm{O}$.

Então,

$$
I=\frac{1}{2} \cdot(1) \cdot(0.025)^{2}+(1) \cdot(0.1)^{2}
$$

que é igual a

$$
I=0.0103 \mathrm{~kg} \cdot \mathrm{m}^{2}
$$

Fazendo o Equilíbrio do sistema da Figura 3.12 tem-se:

$$
-P . a \cdot \operatorname{sen}(\theta)+F(T) . a=I . \ddot{\theta}
$$

onde $F(T)$ é uma entrada em pulso unitário.

Substituindo as variáveis e linearizando a eq. (18) para pequenos deslocamentos:

$$
-(10) \cdot(0,1) \cdot(\theta)+F(T) \cdot(0,1)=(0,0103) \cdot \ddot{\theta}
$$

Aplicando a transformada de Laplace à expressão (19), obtém-se:

$$
-\theta(s)+F(s) \cdot(0,1)=(0,0103) \cdot s^{2} \cdot \theta(s)
$$

Que rearranjando, pode-se obter a seguinte função de transferência em malha aberta:

$$
\frac{\theta(s)}{F(s)}=\frac{0,1}{0,0103 \cdot s^{2}+1}
$$


Para se calcular a função de transferência em malha fechada de um sistema, é utilizada a eq. (21) (OGATA, 1997).

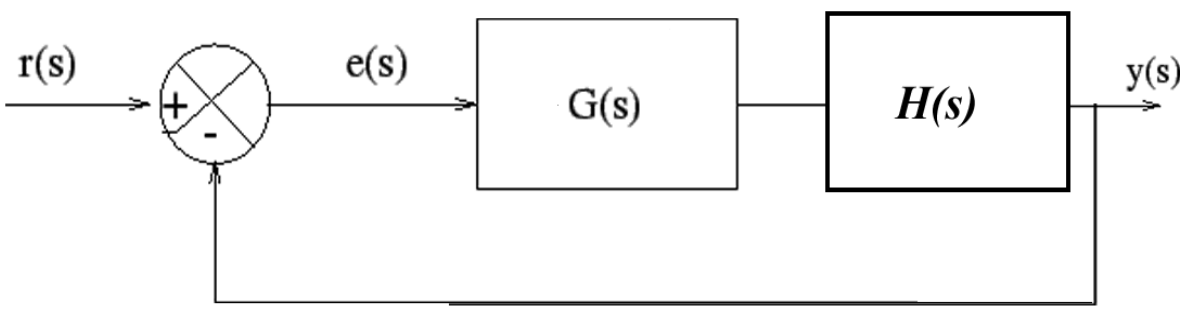

Figura 3.13 - Esquema do controlador

onde $H(s)$ é o controlar a ser utilizado e $G(s)$ é a função de transferência em malha aberta do sistema.

$$
f(s)=\frac{G(s) \cdot H(s)}{1+G(s) \cdot H(s)}
$$

Para um controlador derivativo tem-se:

$$
H(s)=K_{d} \cdot s
$$

Para se ter um sistema estável, a função de transferência em malha fechada do sistema tem que possuir todos os pólos no semiplano esquerdo de $s$ (OGATA,1997). Substituindo as eqs. (21) e (23) em (22), obtém-se:

$$
f(s)=\frac{0,1 \cdot K_{d} \cdot s}{0,0103 \cdot s^{2}+0,1 \cdot K_{d} \cdot s+1}
$$

Calculando o ganho $K_{d}$ para que os pólos estejam no semiplano esquerdo de $s$ :

$$
\begin{aligned}
& \Delta=0,01 \cdot K_{d}{ }^{2}-4 \cdot(0,0103) \cdot(1) \\
& s=\frac{-0,1 \cdot K_{d} \pm \sqrt{0,01 \cdot K_{d}^{2}-4}}{0,02}
\end{aligned}
$$


Basta que $K_{d}>0$, pois para esses valores de $K_{d}$, a eq. (24) é limitada e possui todos os pólos no semiplano esquerdo de $s$.

\subsubsection{Implementação do Controle em Hardware}

A implementação do controle em hardware foi feito em um microcontrolador PIC. Foram criadas três zonas de operação do tensionador, onde duas delas significam zonas de risco (o fio de corte corre risco de romper ou de ficar sem tracionamento) e uma zona central, onde o tensionador deve trabalhar na maior parte do tempo, Figura 3.14.

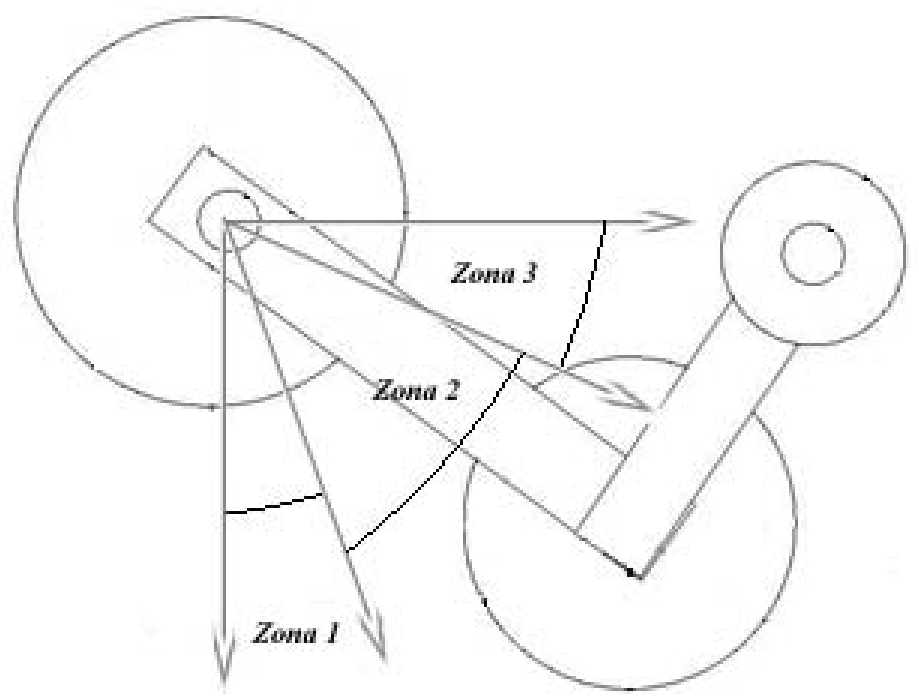

Figura 3.14 - Zonas de controle de tensão

Zona 1: Essa é uma área onde a tração no fio corre risco de cessar. Por isso, quando o tracionador entra nessa zona, automaticamente o cálculo da relação de velocidade entre os motores 1 e 2 é revista pelo microcontrolador, a fim de que se acelere a rotação do motor responsável por enrolar o fio, de um determinado valor para que o mecanismo volte a funcionar dentro da zona 2.

Zona 2: Essa é a zona onde não há perigo do fio de corte se romper por excesso de tracionamento ou a mesma cessar. É a faixa de operação onde preferencialmente a 
máquina deve operar. Nessa zona de operação é onde ocorre o controle derivativo, pois aqui ocorre a aquisição de dados do sensor relativo à mudança do ângulo do tracionador em um certo intervalo de tempo, e baseado nessa mudança são feitas correções na relação de velocidades nos motores responsáveis por fazer o fio circular.

Zona 3: Por isso, quando o tracionador entra nessa zona, automaticamente o cálculo da relação de velocidade entre os motores 1 e 2 é revista pelo microcontrolador, adotando-se assim um valor um pouco fora dos padrões para a relação de velocidade desses dois motores assim fazendo com que o tracionador volte a funcionar dentro da zona 2.

\subsubsection{Cálculo da Resposta do Sensor de Tração}

É sabido que o mecanismo que compõe o sensor de tração responderá bem até a primeira freqüência natural do mecanismo. Para se calcular essa resposta máxima do sensor, escreve-se a seguinte equação diferencial linearizada baseada na eq. (18):

$$
-P . a . \theta+F(T) \cdot a=I . \ddot{\theta}
$$

Reescrevendo, fica:

$$
\ddot{\theta}+\frac{P a}{I} \theta=\frac{F(T) \cdot a}{I}
$$

Assim, calcula-se a freqüência natural do mecanismo do sensor:

$$
f_{n}=\sqrt{\frac{P \cdot a}{I}}
$$




$$
\begin{aligned}
& f_{n}=\sqrt{\frac{(10) \cdot(0,1)}{0,0103}} \\
& f_{n}=9,5 \mathrm{~Hz}
\end{aligned}
$$

\subsubsection{Análise da Ressonância do Fio de Corte}

Analisando-se as duas situações onde é considerada o fio com uma região livre de 300 mm e um diâmetro de 0,14 mm, tanto preso como solto nas extremidades, podese prever que a situação de ressonância do fio, irá se situar em um meio termo dos dois casos, já que em um momento pode se considerar que o fio está preso nas extremidades (quando os dois motores estão parados), e em outro momento pode se considerar que nas extremidades o fio está livre (quando os dois motores responsáveis por enrolar e desenrolar o fio estão em movimento), (Sahoo et al,1998).

De acordo com Seto(1971), a equação que define a freqüência de ressonância de um fio, preso nas duas extremidades e que possui um vão livre de comprimento $L$, massa por unidade de comprimento $\rho$ e densidade $\sigma$, é dada pela equação (32):

$$
f_{n f}=\frac{\pi}{L} \cdot \sqrt{\frac{T}{\rho}}
$$

assim:

$$
\begin{aligned}
& f_{n f}=\frac{\pi}{L} \cdot \sqrt{\frac{T}{\pi \cdot r^{2} \cdot \sigma}} \\
& f_{n f}=\frac{\pi}{0,3} \cdot \sqrt{\frac{10}{\pi \cdot(0,007)^{2} \cdot 7830}} \\
& f_{n f}=29 \mathrm{~Hz}
\end{aligned}
$$




\subsubsection{Cálculo da Relação de Velocidades}

Supondo que o carretel onde se encontra todo o fio no começo do processo tenha velocidade $V_{1}$, então para obter um movimento onde o tensionador fique a maior parte do tempo na zona 2 tem-se que $V_{2}$ tem que ser igual a $V_{1}$, então:

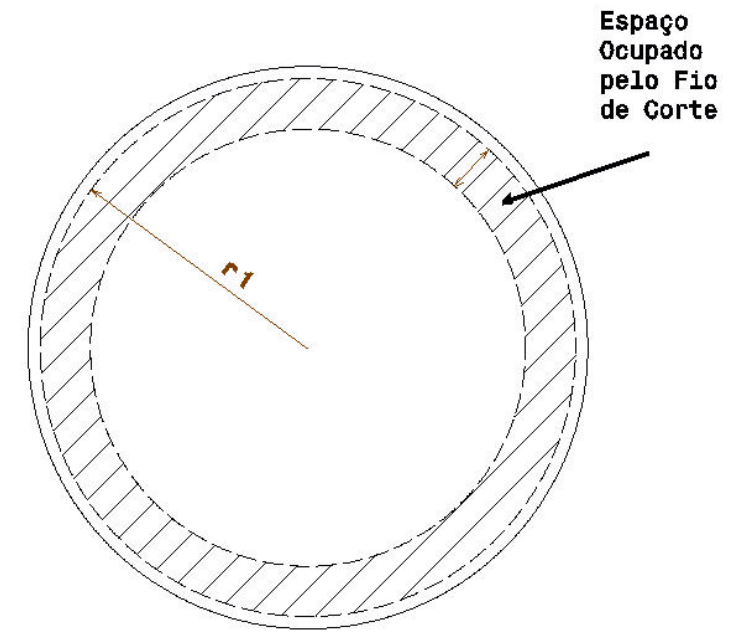

Carretel Cheio

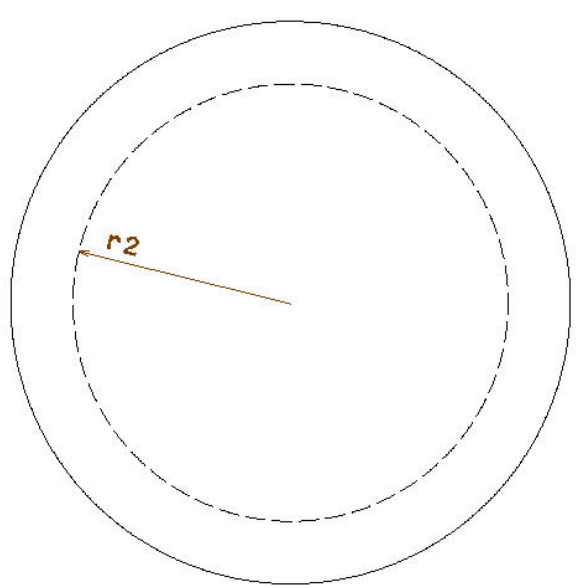

Carretel Vazio

Figura 3.15 - Estado inicial dos carretéis

$$
V_{2}=V_{1}
$$

ou seja,

$$
k_{r} \cdot \frac{2 \cdot \pi \cdot r_{2}}{\Delta t}=\frac{2 \cdot \pi \cdot r_{1}}{\Delta t} \rightarrow k_{r}=\frac{r_{1}}{r_{2}}
$$

como:

$$
r_{1}=25 m m \text { e } r_{2}=20 m m
$$

tem-se que: 


$$
k_{r}=1,25
$$

De acordo com a eq. (39), o controlador tem, preferencialmente, que ser iniciado com um ganho de 1,25 quando se utiliza um carretel novo. Esse ganho vai variando conforme o carretel vazio vai se enchendo de fio, pois o fio não é enrolado de forma uniforme, fazendo com que o diâmetro do carretel vazio cresça em torno de $50 \%$ em relação ao seu diâmetro inicial, isso faz com que o valor do ganho se altere de 1,25 para até 0,6, como esquematizado na Figura 3.16

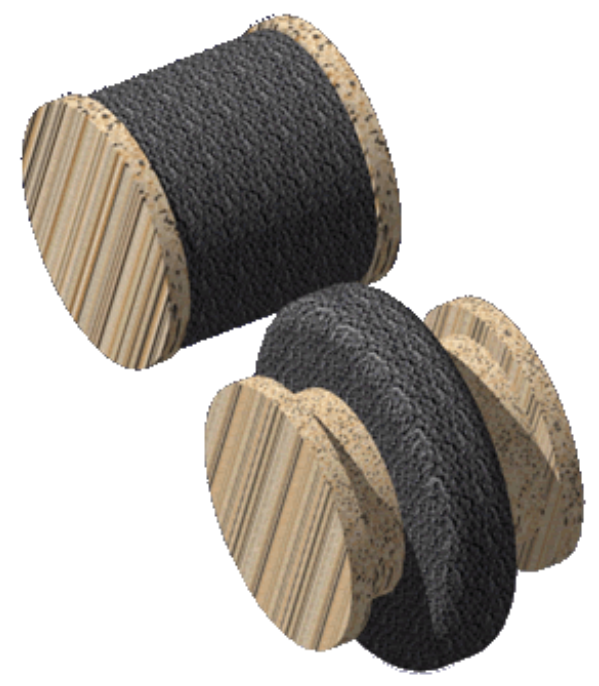

Figura 3.16 - Estado final dos carretéis

\subsubsection{Controlador}

Como controlador do dispositivo de corte foi escolhido o PIC16F877 e a partir dele foi projetado uma interface eletrônica para que a máquina fosse totalmente autônoma sem a necessidade de computadores tipo PC. Essa interface possui um conversor analógico digital para a leitura do ângulo A do mecanismo tensionador, cinco saídas para os "drivers" que controlam os 4 motores de passo, sendo que 4 bits da placa controlam a movimentação de 0,8 graus de cada um dos quatros motores, e 1 bit controla a direção que eles têm que girar. A interface ainda possui 
saída para um display LCD que é responsável por fornecer algumas informações ao usuário e ao mesmo tempo pedir valor de variáveis necessários a usinagem da cerâmica. A Figura 3.17 e a Figura 3.18 mostram os fluxogramas de controle de tensão no fio e da interface homem-máquina.

A Figura 3.18 mostra como estão divididas as entradas e saídas do microcontrolador para o controle do dispositivo de corte, bem como qual a função de cada componente dentro do sistema de controle.

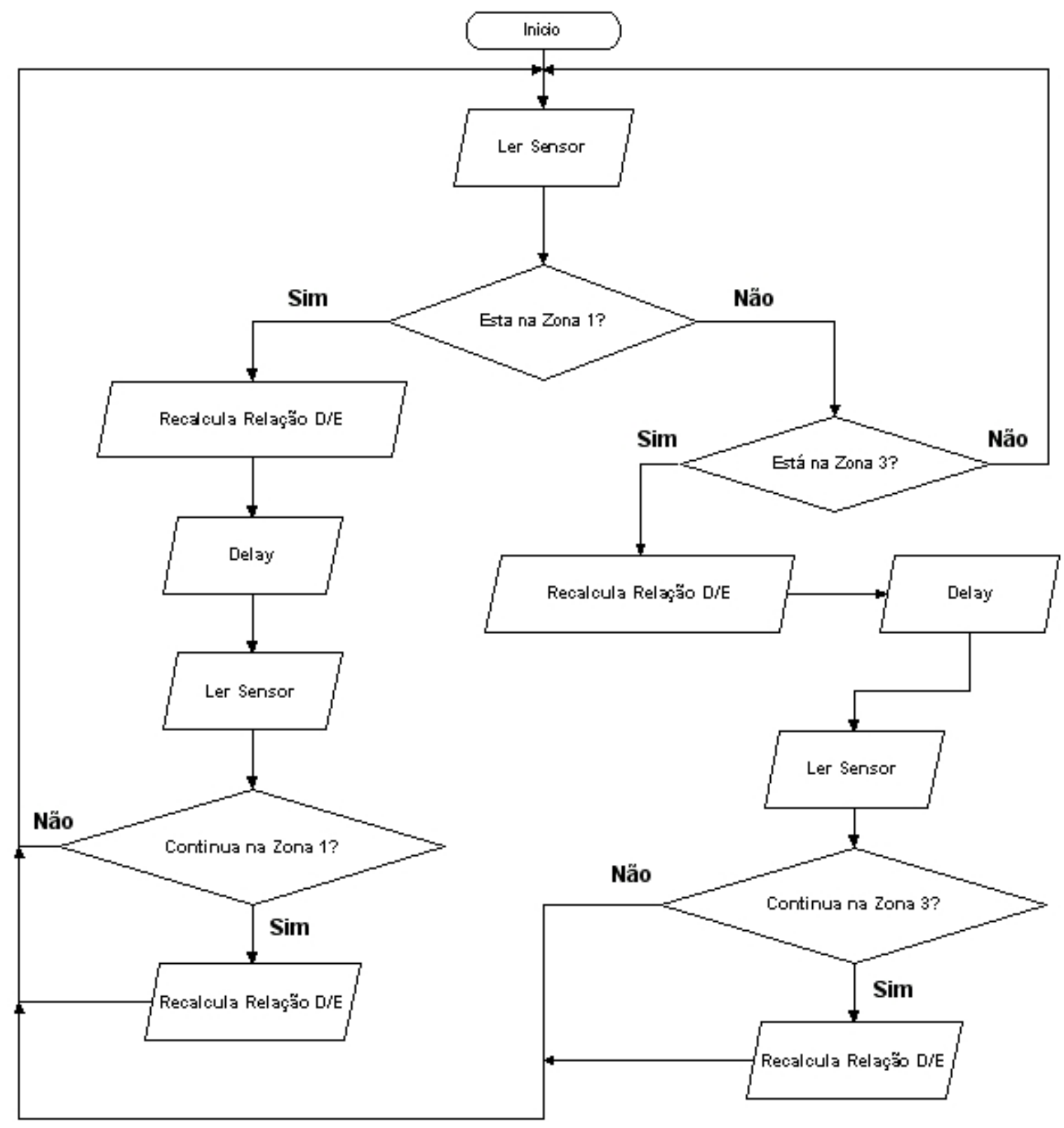

Figura 3.17 - Fluxograma do controle da tensão no fio 


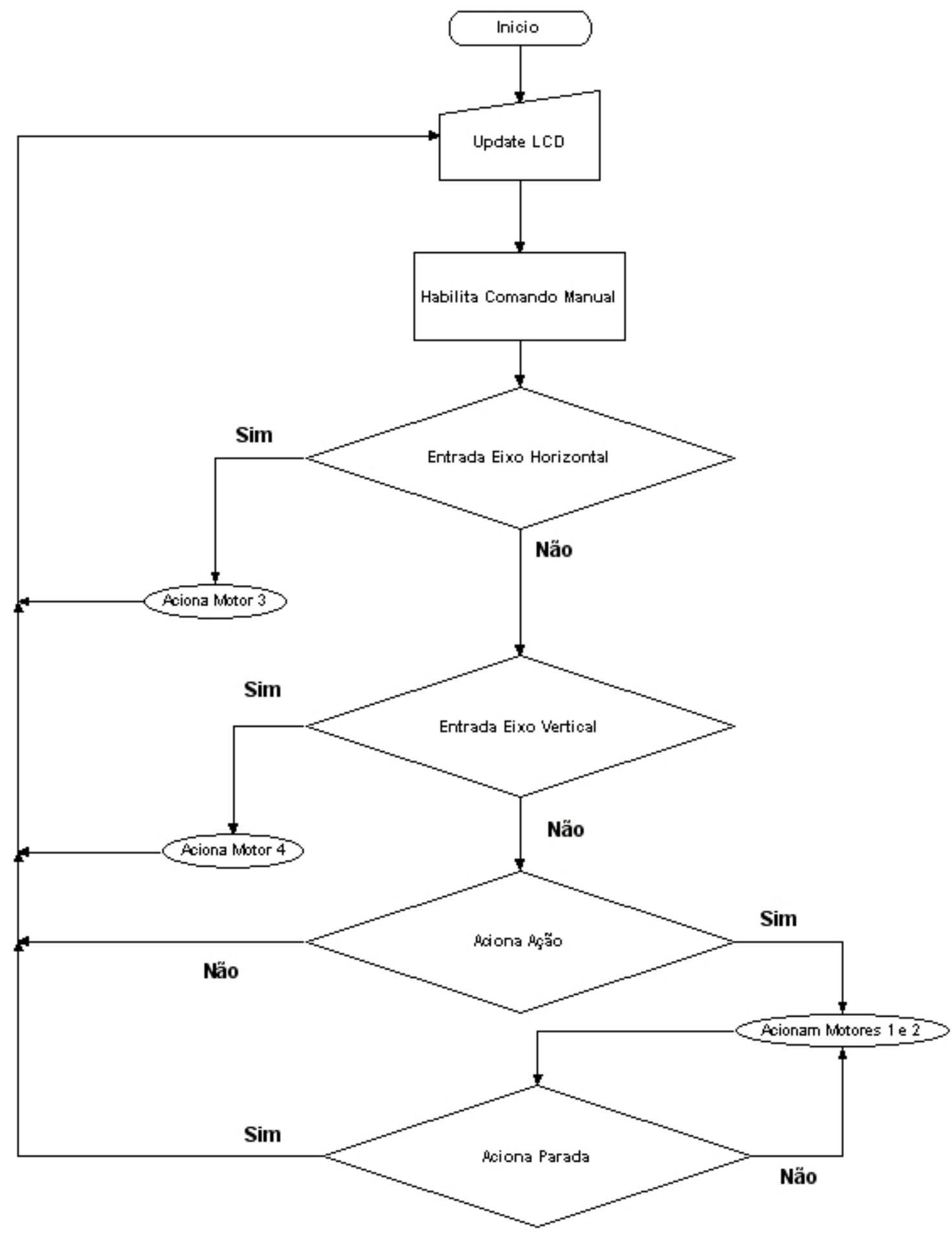

Figura 3.18- Fluxograma das ações do controlador 


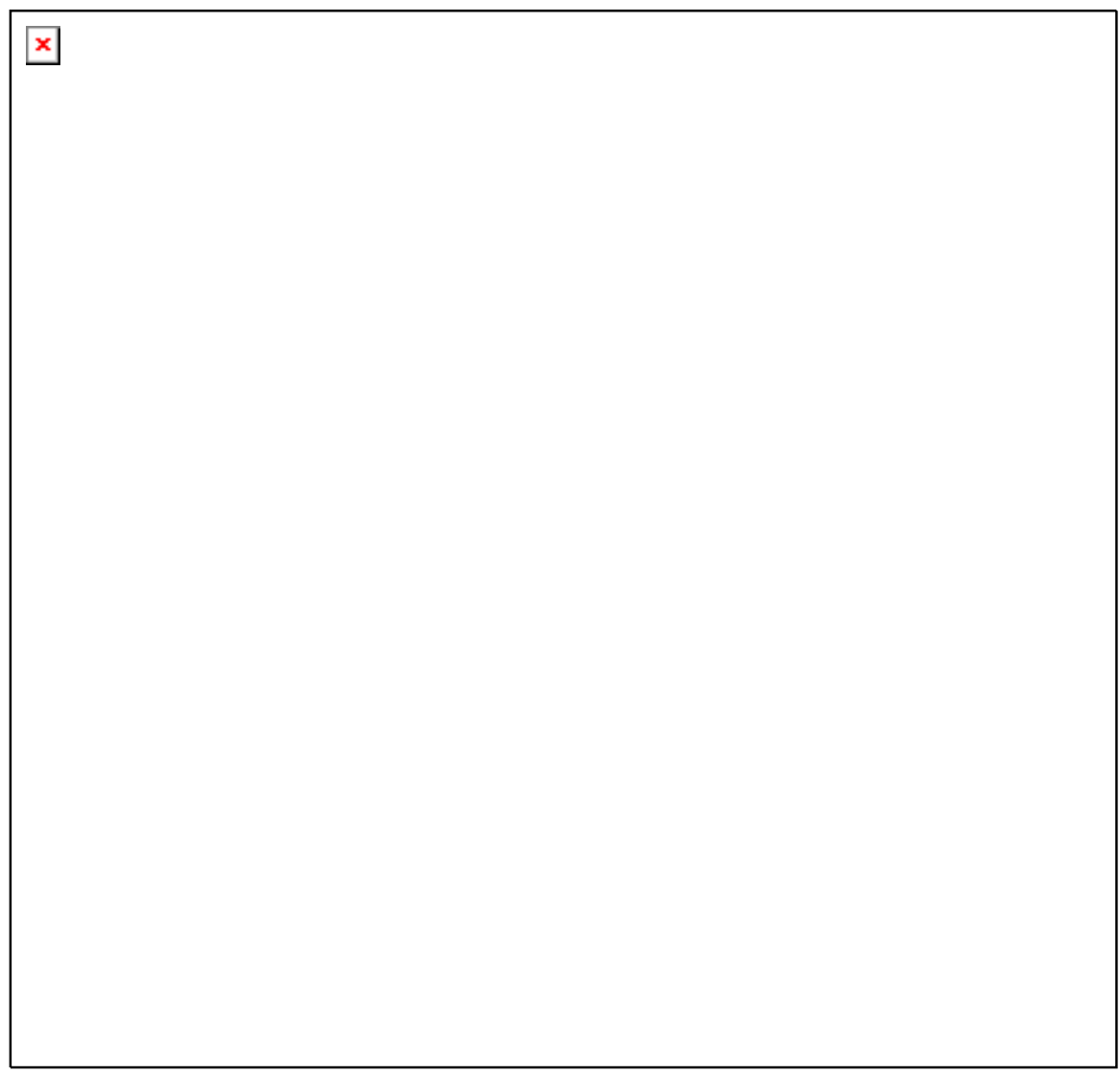

Figura 3.19 - Esquema do Controlador

A interface eletrônica possui mais 6 bits de entrada, que servem para a interação do usuário, ou seja, para o usuário ter a possibilidade de comandar a máquina manualmente, bem como entrar com algumas informações que são necessárias ao funcionamento da mesma. O painel foi super dimensionado com o propósito de no futuro agregar ainda mais funções pré programadas.

A interface ainda contém um conector ICSP, responsável pela atualização do "firmware" da máquina, e é compatível com quase a totalidade dos programadores de microcontrolador. A Figura 3.20 mostra como estão distribuído os motores pela máquina de corte. 


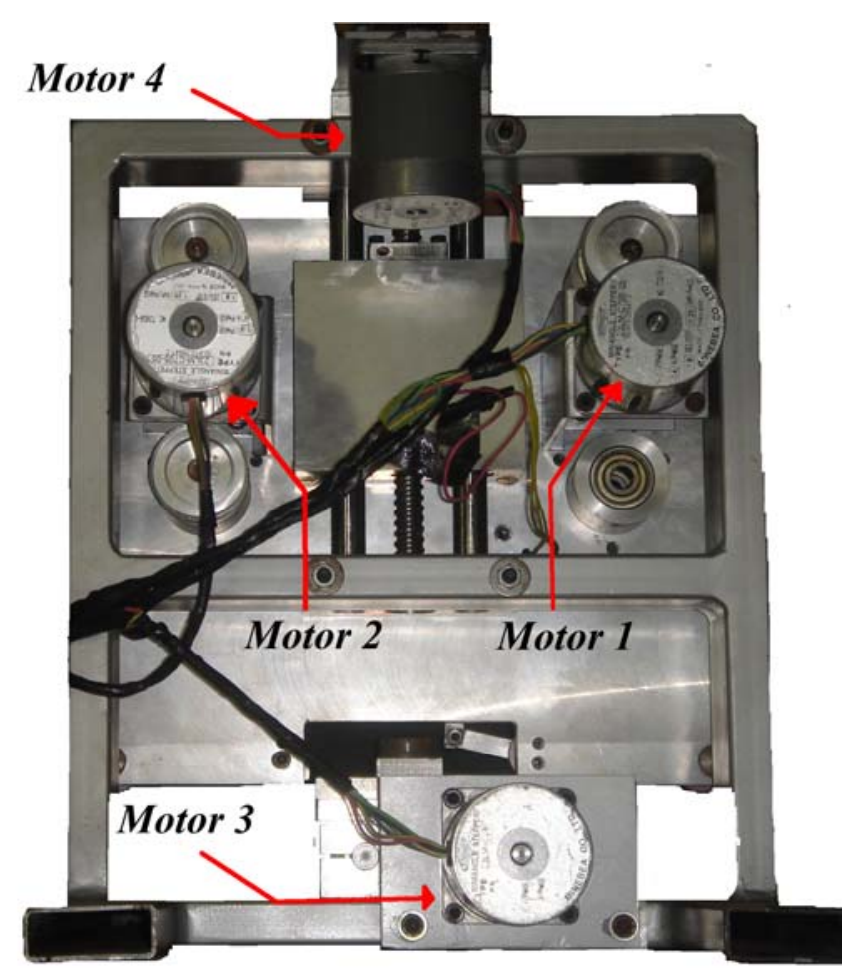

Figura 3.20 - Distribuição dos Motores

\subsection{INTERPOLAÇÃO DOS MOTORES}

O algoritmo do software de interpolação dos motores, responsáveis por enrolar e desenrolar o fio de corte, possui a função de enrolar e desenrolar o fio de forma a não alterar a tensão normal no fio. Isso se deve ao cálculo da relação de transmissão entre o carretel responsável pelo processo de enrolar e o carretel responsável por desenrolar o fio de corte e também a modificação de um algoritmo chamado Bresenham, utilizado para traçar linhas graficamente (ANNIBAL,2006), para que ele assumisse a função de interpolar os movimento dos motores citados de tal maneira a não causar maiores perturbações no tensionamento do fio.

A Figura 3.21, mostra qual é o resultado do algoritmo quando a relação de transmissão entre o carretel que enrola e o que desenrola o fio de corte é igual a 1 para 1. A Figura 3.22 mostra o resultado do algoritmo quando a relação de transmissão entre os carretéis é de 2 para 1. 


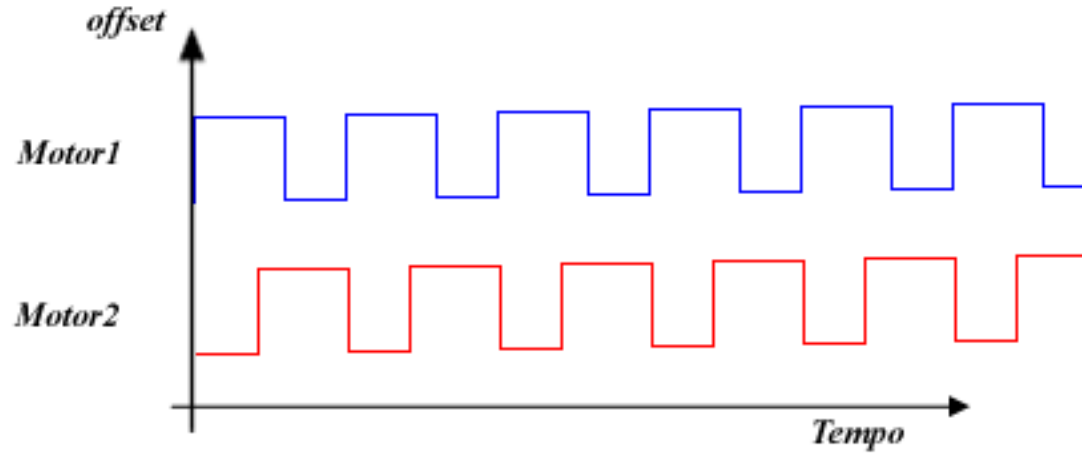

Figura 3.21- Sinais de comando para os Motores para relação de transmissão 1:1

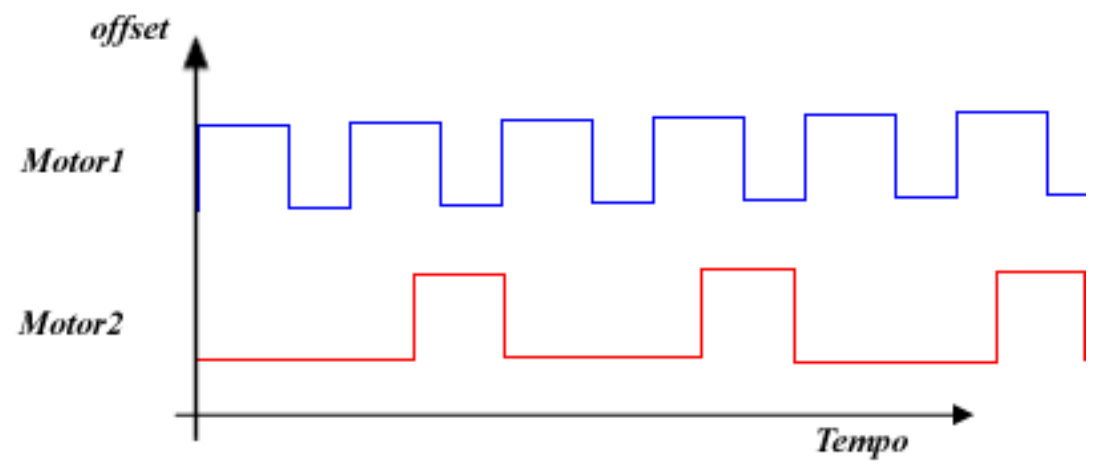

Figura 3.22 - Sinais de comando para os Motores para relação de transmissão 2:1 


\section{ESTUDO DA ABRASÃO DE CERÂMICAS}

\subsection{INTRODUÇÃO}

As aplicações para esse tipo de material são variadas. Muitos tipos de cerâmicas são usados na indústria eletroeletrônica, porque possuem alta resistência elétrica, alta força dielétrica (tensão necessária para ruptura elétrica por unidade de espessura) e propriedades magnéticas úteis para aplicações como imãs permanentes e para auto-falantes.

O uso de cerâmicas como revestimento de metais é um outro tipo de aplicação. Isso é feito para a redução de desgaste, prevenção à corrosão, ou prover uma eficiente barreira térmica.

\subsection{PROCESSOS DE USINAGEM ABRASIVOS}

Processos de usinagem abrasivos são técnicas de fabricação que utilizam partículas granulares muito duras na usinagem, visando modificar a forma e a textura das peças fabricadas (MARINESCU at al., 2004).

Uma larga variedade desses processos é utilizada para produzir peças de alta qualidade com alta precisão e pequenas tolerâncias. Existem exemplos desde peças pequenas tais como lente de contato, agulhas, componentes eletrônicos, "wafers" de silício e rolamentos de esfera.

Enquanto precisão e qualidade do acabamento superficial são motivos para selecionar processos abrasivos, existe um outro motivo importante: processos abrasivos são a escolha natural para usinagem e acabamento de materiais duros e superfícies endurecidas.

A maioria dos processos abrasivos pode ser dividida em um dos quatro grupos (STACHOWIAK, 2001): 
- $\quad$ Retificação;

- Brunimento;

- Lapidação;

- $\quad$ Polimento.

\subsubsection{Retificação}

No processo de retificação, Figura 4.1, a ferramenta abrasiva é o rebolo que se movimenta a uma alta velocidade superficial, se comparado a outros processos de usinagem tais como fresamento ou torneamento. As velocidades de superfícies estão tipicamente entre $20 \mathrm{~m} / \mathrm{s}$ a $45 \mathrm{~m} / \mathrm{s}$ no processo de retificação convencional. Nesse caso, o abrasivo está preso à ferramenta de corte.

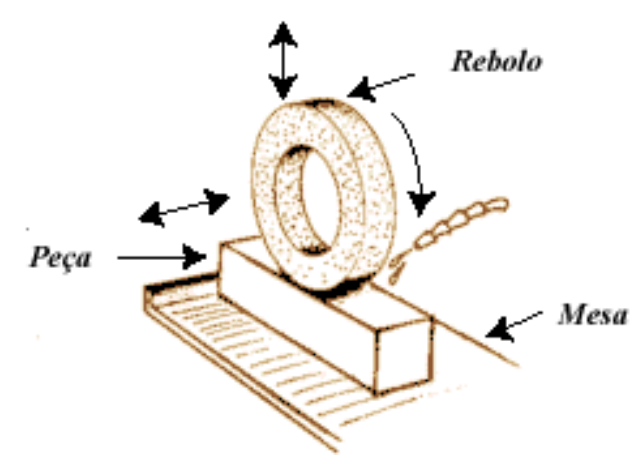

Figura 4.1 - Processo de retificação

\subsubsection{Brunimento}

No brunimento, Figura 4.2, as partículas abrasivas ou grãos, como são popularmente conhecidos, são fixados na ferramenta assim como acontece no processo de retificação. O processo de brunimento é usado principalmente para o acabamento superficial no furo de um cilindro. As pedras de brunir são 
pressurizadas radialmente para fora contra o furo. Brunir é diferente de retificar por dois motivos:

- A ferramenta abrasiva se movimenta a baixas velocidades em relação à peça a ser trabalhada. Tipicamente a velocidade de superfície é de 0,2 m/s a $2 \mathrm{~m} / \mathrm{s}$.

- A ferramenta de brunir tem um alinhamento flexível à superfície da peça de trabalho. Isso significa que a excentricidade do furo relativo ao diâmetro externo não pode ser corrigida.

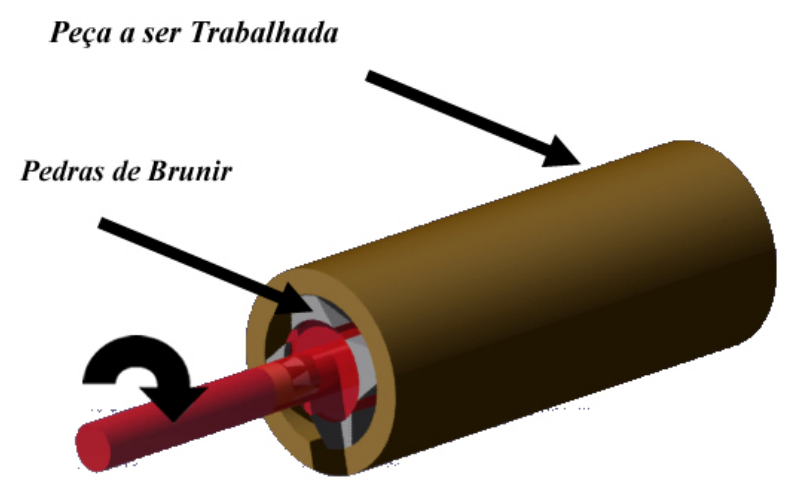

Figura 4.2 - Processo de brunimento

\subsubsection{Lapidação}

Na lapidação, Figura 4.3, o abrasivo livre é introduzido na interface entre um molde, que pode ser de placa de aço, e a superfície da peça a ser trabalhada. O abrasivo livre é normalmente suspenso em um líquido, como por exemplo, óleo, que fornece lubrificação e ajuda a transportar o abrasivo. O molde de placa de aço e a peça a ser trabalhada sofrerão desgaste. Para manter a geometria desejada da peça é necessário prestar atenção na natureza do movimento envolvido para nivelar o desgaste através das superfícies envolvidas. Muitos moldes podem ser empregados e periodicamente revezados no processo. 


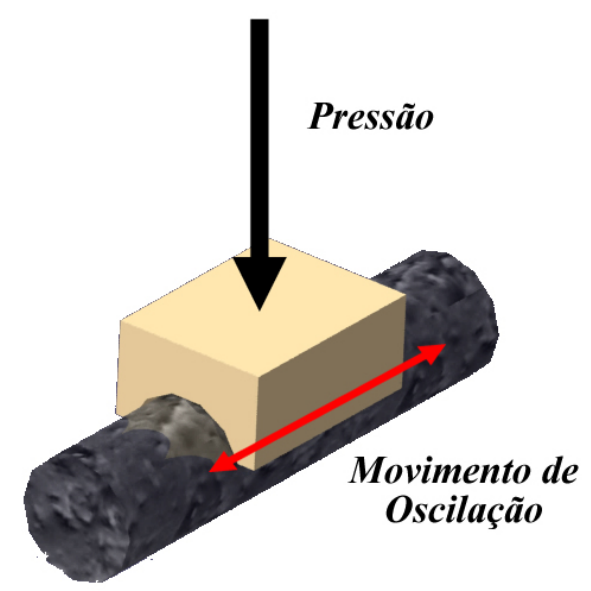

Figura 4.3 - Processo de lapidação

\subsubsection{Polimento}

Polimento, como a lapidação, também utiliza abrasivos livres. Nesse caso, a pressão é aplicada através de um sólido conformável ou de um material macio.

Isso permite que o abrasivo siga os contornos da superfície da peça a ser usinada e limite a penetração de grãos individuais na superfície. Se o polimento ocorrer com um abrasivo fino, ocorre uma abrasão sutil entre os grãos e a peça de trabalho que assegura uma usinagem com marcas de profundidade muito pequenas.

O objetivo do polimento é modificar mais a textura da superfície do que sua forma. Espelhos de alta reflexão podem ser produzidos por polimento. O material é removido a uma taxa muita pequena. Conseqüentemente, a geometria da superfície precisa ser bem próxima à forma correta antes de se polir essa superfície.

\subsubsection{O Abrasivo}

Em todas as quatro classes dos processos que utilizam abrasivo na usinagem, o grão abrasivo tem que ser mais duro do que a peça de trabalho no ponto de 
interação. Isso significa que o grão deve ser mais duro que a peça de trabalho na temperatura de interação. Essas temperaturas de curta duração podem ser muito altas, por isso os grãos abrasivos devem manter sua dureza mesmo em altas temperaturas (WILLIAM I. et al., 2003).

Isso é verdadeiro em todos os processos abrasivos sem exceção, se a peça de trabalho for mais dura que o abrasivo, então o abrasivo sofrerá maior parte do desgaste.

\subsection{PRINCÍPIOS TRIBOLÓGICOS}

Os princípios científicos sobre o processo de usinagem por abrasão fazem parte do domínio da tribologia. Tribologia é definida como o estudo do atrito, lubrificação e desgaste.

$\mathrm{Na}$ usinagem, o material removido da peça de trabalho é denominado cavaco. Esse material deve ser cortado da peça de forma limpa ao invés de arrancá-lo do mesmo por lixamento. Em uma máquina o objetivo geralmente é minimizar o desgaste de um elemento crítico. No entanto, na usinagem abrasiva o objetivo é maximizar essa taxa de desgaste.

$\mathrm{Na}$ usinagem abrasiva, os objetivos principais são normalmente minimizar o atrito e o desgaste do abrasivo e maximizar o desgaste da peça de trabalho. Outros objetivos são em relação à qualidade da peça, incluindo os requisitos da textura da superfície e evitando danos superficiais 
4.4 MECANISMOS DE DESGASTE DE MATERIAIS CERÂMICOS

\subsubsection{Abrasão a 2 Corpos}

$\mathrm{Na}$ abrasão a 2 corpos é assumido que as partículas abrasivas fazem parte da ferramenta (Figura 4.4a). O movimento relativo entre o abrasivo e a peça de trabalho é considerada de puro escorregamento.

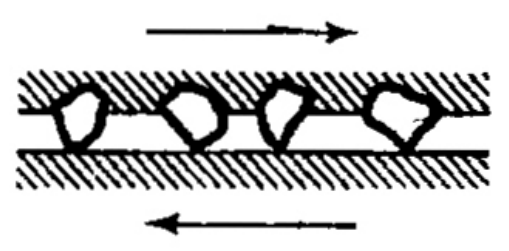

(a) Abrasão a 2 corpos

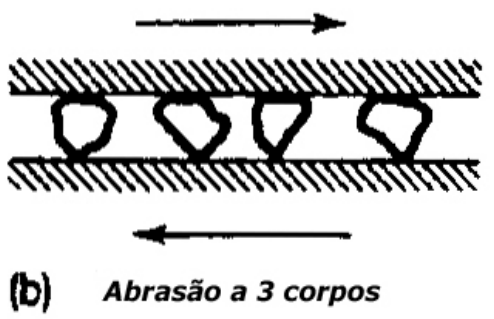

Figura 4.4 - Mecanismos de desgaste

\subsubsection{Abrasão a 3 Corpos}

$\mathrm{Na}$ abrasão a 3 corpos, os grãos abrasivos são livres para rodar e escorregar, experimentando colisões com a peça de trabalho, com o molde e com outros grãos abrasivos (Figura 4.4b). Do ponto de vista energético, esse processo é menos eficiente pois há colisões que levam a dissipação de energia. No entanto, existe uma vantagem no processo a 3 corpos que é a rotação de grãos, assim novas arestas de corte podem ser trazidas à ação. 
Na prática, o processo de abrasão a 2 corpos envolve um elemento de abrasão a 3 corpos, pois o material que é erodido da peça de trabalho e as partículas abrasivas faturadas ficam livres na interface, formando assim, as condições para se ter 0 processo abrasivo a 3 corpos. De certa forma, a abrasão a 3 corpos no processo de abrasão a 2 corpos pode causar problemas de qualidade, pois o material perdido pode ficar incrustado na peça de trabalho. Partículas incrustadas que depois se destacam da peca de trabalho, criam uma superfície na peça que pode danificar outras superfícies que entrem em contato com ela.

\subsection{PROPRIEDADES DA PARTÍCULA ABRASIVA}

\subsubsection{Dureza da Partícula}

A dureza da partícula envolvida na abrasão influencia diretamente na taxa de desgaste. Partículas com durezas mais baixas do que a dureza da superfície da peça a ser desgastada, causam menor desgaste do que partículas mais duras. Para partículas significativamente mais duras do que o valor exato da dureza da superfície, a dureza nesses casos assume um caráter menos importante. Como pode-se ver no gráfico da Figura 4.5, que traduz um ensaio feito com vários tipos de metais e cerâmicas desgastados por vários tipos de abrasivo, a taxa de desgaste é muito mais sensível à razão da dureza do abrasivo $\mathrm{Ha}$ em relação à dureza da superfície Hs quando Ha / Hs é menor que 1 (HUTCHINGS,1992). 


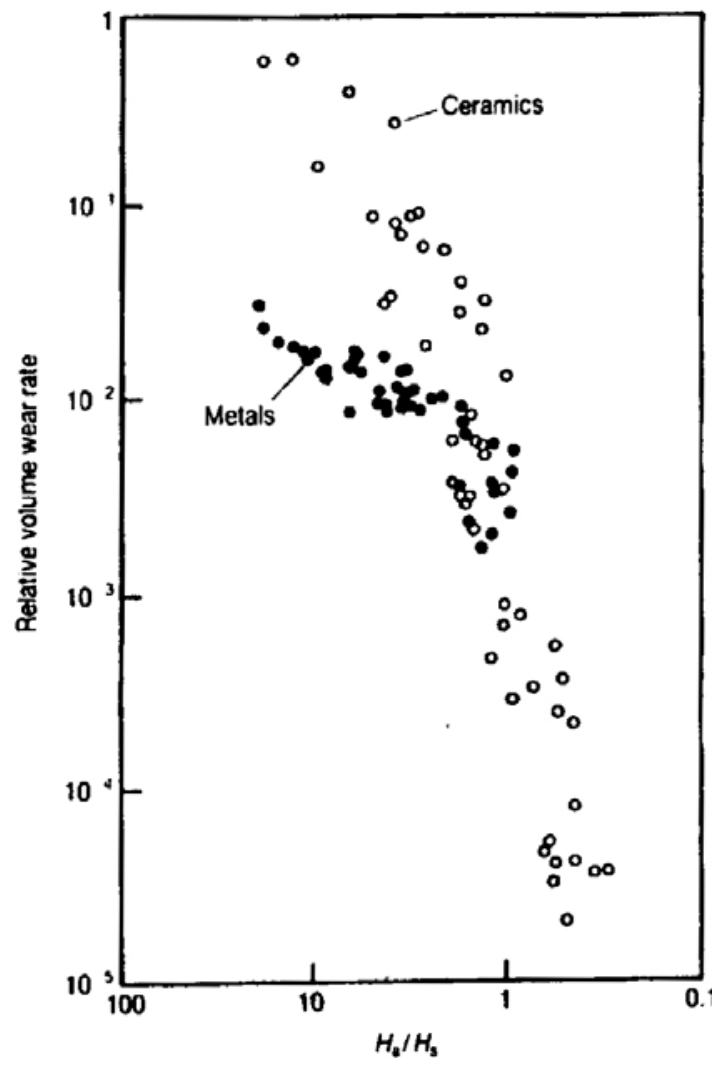

Figura 4.5 - Relação Ha I Hs x volume desgastado

Se o material da superfície fluir plasticamente, já que seu limite elástico foi ultrapassado, ocorrerá deformação plástica relevante na superfície quando a pressão de contato média atingir aproximadamente três vezes sua tensão de limite elástica axial Y. Esta pressão de contato é a dureza à penetração da superfície e depende pouco da forma detalhada da partícula. A deformação plástica da superfície ocorrerá conforme se aumenta a carga normal da partícula, e ainda somente se a partícula puder sustentar esta pressão de contato sem se deformar. Se a partícula falhar por deformação ou fraturar antes que a pressão na superfície atinja $\sim 3 Y$, então não ocorrerá ou ocorrerá uma deformação insignificante na superfície.

Para uma partícula esférica pressionada contra uma superfície chata, a pressão máxima de contato é de aproximadamente 0,8 vezes a dureza de penetração do material da partícula. Por isso, é esperado que uma esfera de dureza $\mathrm{Ha}$ cause deformação plástica em uma superfície de dureza $H s$, se $H s$ for menor que $\sim 0,8 \mathrm{Ha}$, ou seja, $\mathrm{Ha} / \mathrm{Hs}>1,25$. Um resultado semelhante pode ser obtido para outras geometrias de contato, e é observado experimentalmente que partículas de grãos abrasivos de qualquer forma causarão desgaste plástico somente se $\mathrm{Ha} / \mathrm{Hs}$ 
$>1,2$. Abrasão sob condições onde $H a / H s<1,2$ é, às vezes, chamada de abrasão leve.

A observação de que existe uma razão mínima de dureza para um material ter a capacidade de desgastar outros materiais através do atrito, fornece o embasamento físico para a escala de dureza formalizada pelo mineralogista austríaco Mohs em 1824. Mohs numerou dez materiais em uma escala de dureza de tal forma que o de valor mais alto seria capaz de desgastar aqueles que teriam o valor mais baixo, Figura 4.6 (SINHA, 2006).

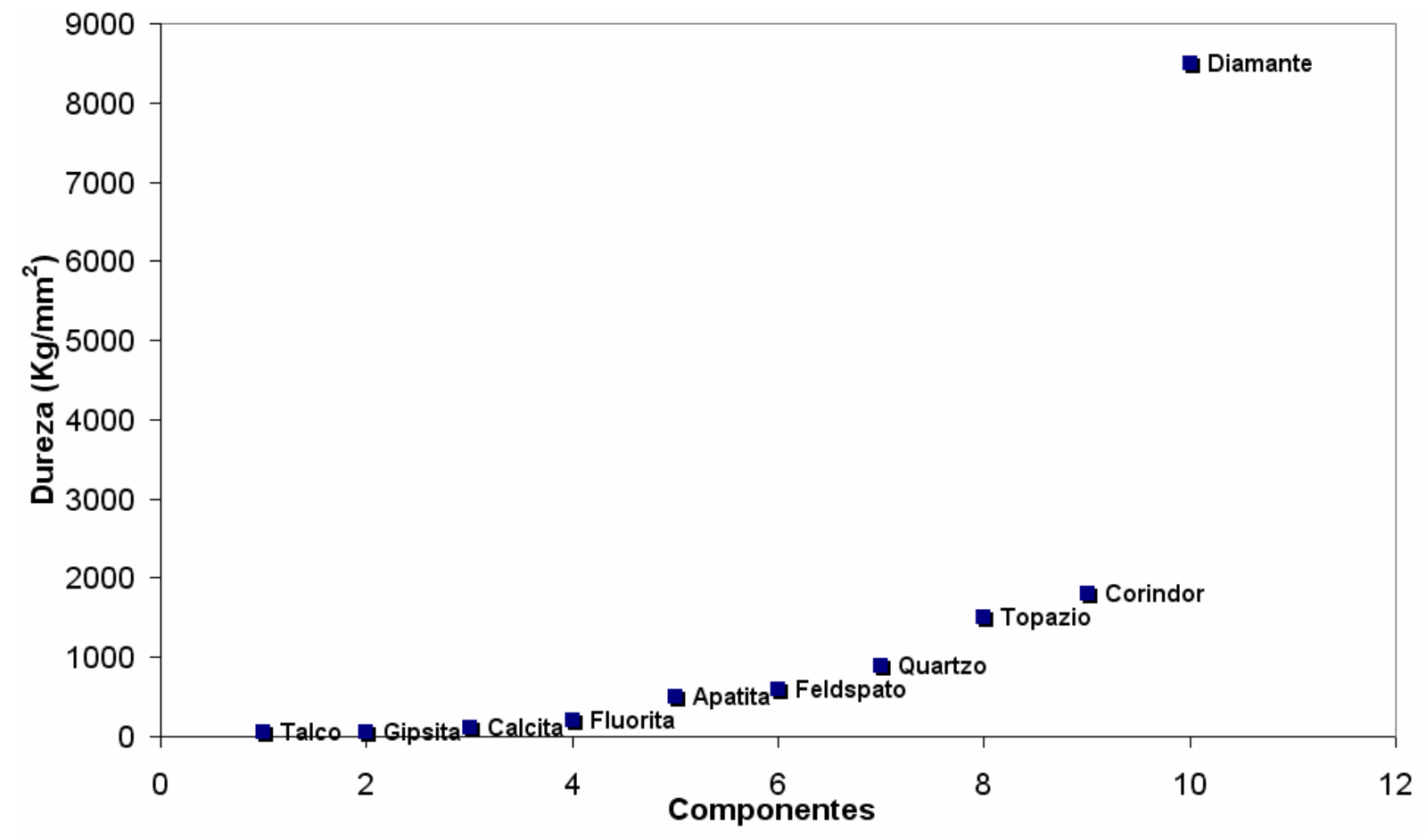

Figura 4.6 - Escala de Mohs

\subsubsection{Forma da Partícula Abrasiva}

A maioria das partículas responsáveis pela abrasão possui uma rugosidade uniforme, porém podem considerar variações no ângulo dessas rugosidades dependendo da sua origem. Taxas de desgaste dependem fortemente da forma da partícula, com partículas em forma de cunhas causando maior desgaste do que partículas em forma de esfera. Diferenças na forma da partícula podem levar a diferenças em taxa de desgaste em um fator de 10 vezes ou mais. 


\subsubsection{Tamanho da partícula abrasiva}

Existem muitos tamanhos para uma partícula responsável pelo desgaste abrasivo, normalmente se encontra na faixa de 5 a $500 \mu \mathrm{m}$. No entanto, para polimento podem ser empregadas partículas menores que $1 \mu m$ (HUTCHINGS, 1992).

Um padrão consistente de comportamento pode ser demonstrado através de testes de laboratório, como pode ser visto nas Figura 4.7 e 4.8. Partículas abrasivas com tamanhos menores que $100 \mu m$ fornecem um desgaste menor na superfície de trabalho do que partículas maiores que $100 \mu \mathrm{m}$. Isso acontece pois existe uma grande dificuldade de nucleação, movimento ou deslocamento em um volume muito pequeno. Os pontos em azul nas figuras 4.7, 4.8, 4.9 e 4.10 se referem aos valores numéricos, e a linha corresponde a uma linha de tendência.

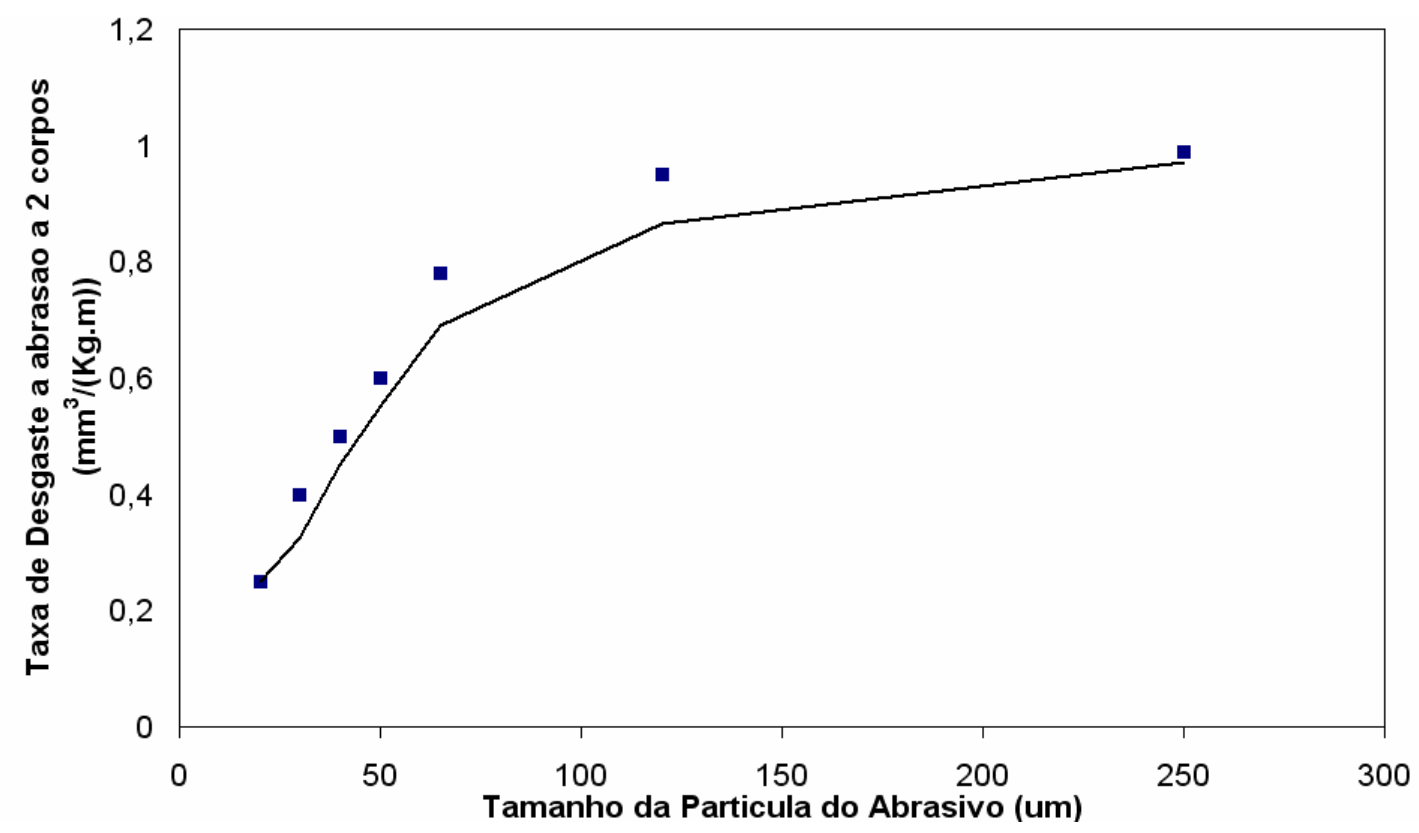

Figura 4.7 - Taxa de desgaste a abrasão a 2 corpos com velocidade relativa 


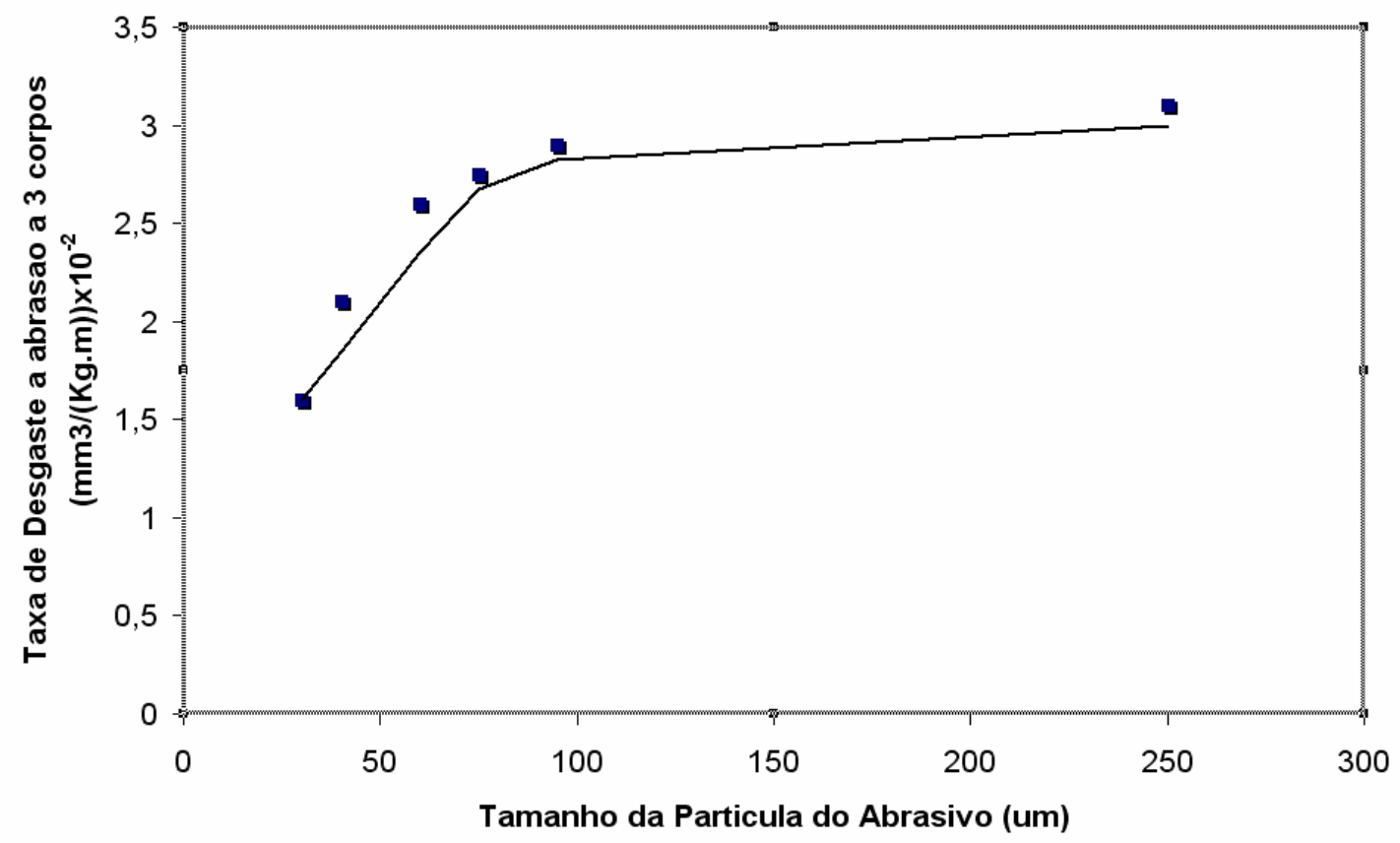

Figura 4.8 - Taxa de desgaste a abrasão a 3 corpos com velocidade relativa $75 \mathrm{~mm} / \mathrm{s} \times$ tamanho da partícula do abrasivo

\subsection{EFEITOS QUÍMICOS}

A Figura 4.9 mostra um exemplo da transição da taxa de desgaste no $S_{3} N_{4}$ causado por um aumento na velocidade de deslizamento. A baixas velocidades com ar úmido, $\mathrm{Si}_{3} \mathrm{~N}_{4}$ forma uma camada superficial de óxido de silício hidratado que fornecem a fonte dos "debris" quimicamente diferentes do substrato. Essa camada possui uma resistência menor de cisalhamento do que o substrato, além de um coeficiente de atrito menor. É possível que a água absorvida na superfície aumente também a probabilidade de deformação plástica. Com o aumento da velocidade tangencial, aumentando também a temperatura da interface, a camada triboquimica reage cessando a proteção aumentando o coeficiente de atrito. O aumento da tensão de cisalhamento causa trincas, e a transição como conseqüência ocorre a transição do regime de desgaste brando para o regime de desgaste severo. Como resultado, ocorre o aumento da rugosidade da superfície que é o maior responsável pelo aumento do coeficiente de atrito (HUTCHINGS, 1992). 


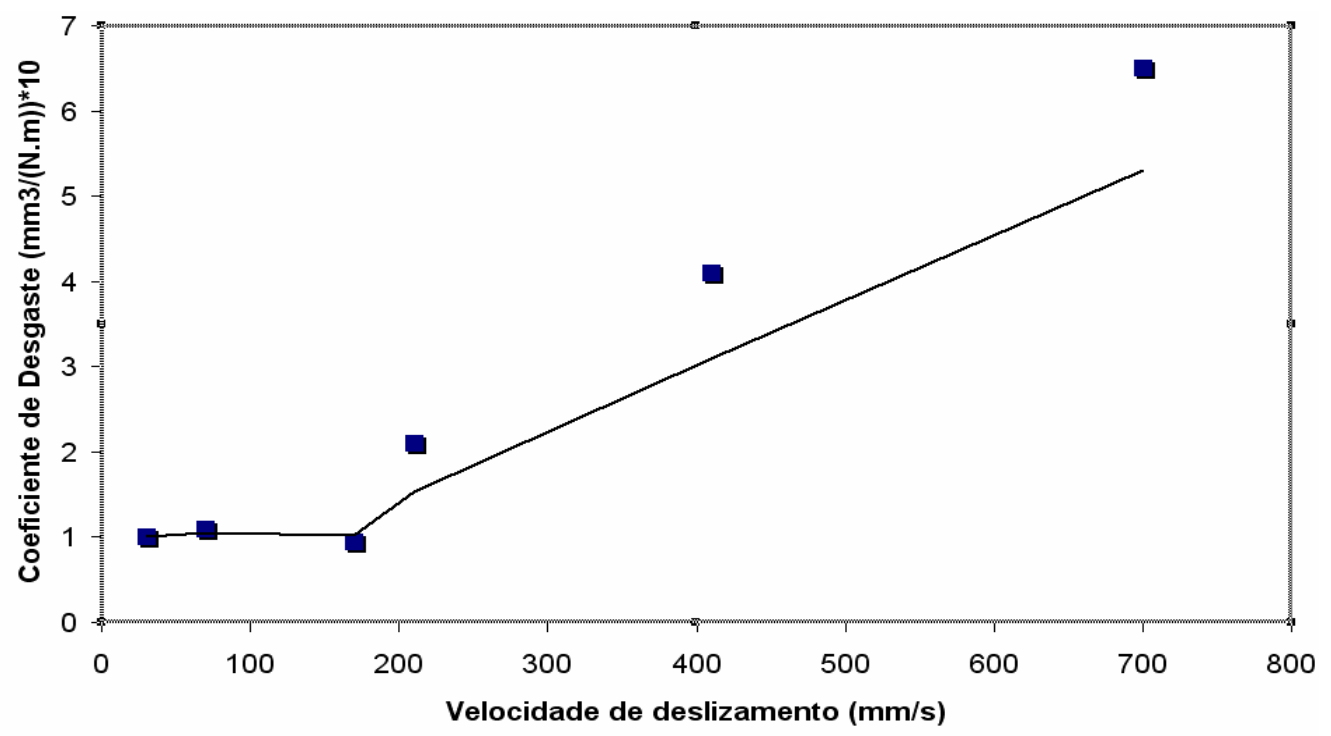

Figura 4.9 - Coeficiente de desgaste $x$ velocidade de deslizamento

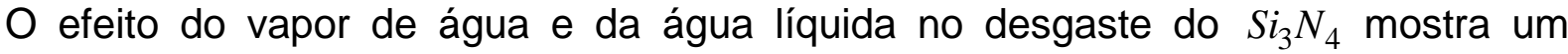
exemplo da sensibilidade ao ambiente, comumente observada no desgaste por deslizamento em cerâmicas, como pode ser visto na figura 4.10. Uma reação triboquímica ocorre no $\mathrm{SiC}$, levando a formação de um óxido de silício, nesse caso a presença de água leva a diminuição da taxa de desgaste(HUTCHINGS, 1992).

Os efeitos químicos podem ser também importantes em altas velocidades de deslizamento, onde o aquecimento da superfície leva ao aumento da taxa de reação com o oxigênio, por exemplo. 


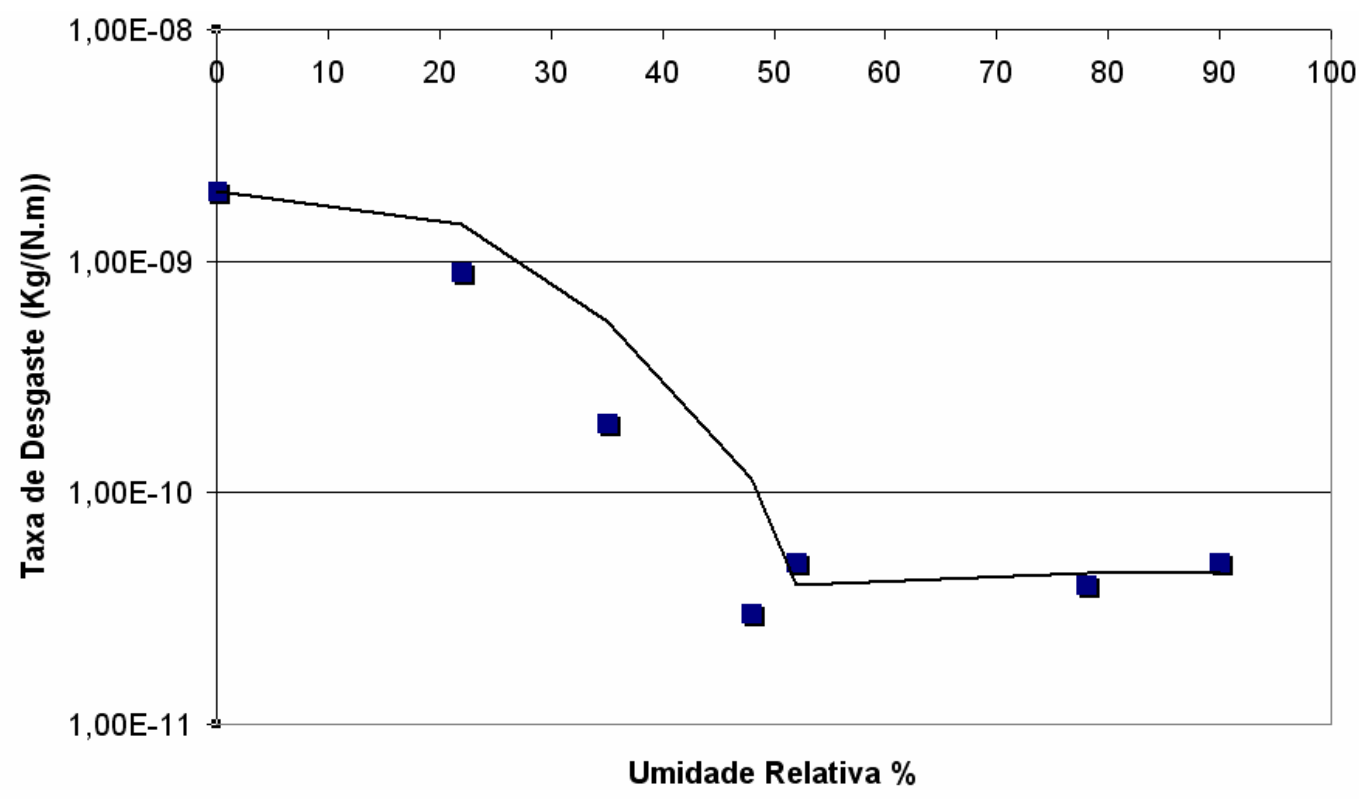

Figura 4.10 - Taxa de desgaste $x$ umidade relativa

\subsection{EFEITOS DA LUBRIFICAÇÃO}

A lubrificação fornece um método poderoso na redução do desgaste e na interação por diversos mecanismos de deslizamento. A lubrificação hidrodinâmica leva a menores taxas do desgaste por deslizamento, porém não é possível manter constantemente condições hidrodinâmicas em um sistema, pois geralmente as condições necessárias deixam de estar presentes quando um sistema é imediatamente ligado ou para de funcionar.

Claramente, a lubrificação hidrodinâmica não é a situação mais desejada para se aplicar quando se quer usinar uma cerâmica através do atrito do fio com o abrasivo. Então, o ideal seria evitar a qualquer custo esse tipo de lubrificação optando por outro tipo de lubrificação, como por exemplo, a lubrificação sólida, ou mesmo tentar a usinagem sem usar qualquer tipo de lubrificação (MARINESCU et al,2004) 


\subsection{TRANSIÇÃO DO DESGASTE BRANDO PARA O DESGASTE SEVERO}

O mecanismo de desgaste por deslizamento nas cerâmicas pode envolver fraturas, efeitos triboquímicos e deformações plásticas. Transições entre esses regimes onde se predominam cada uma dessas características (fraturas, efeitos triboquímicos e deformações plásticas) revelam uma sutil mudança de desgaste em relação à carga normal aplicada, com a velocidade de deslizamento ou nas condições do ambiente. O desgaste brando nas cerâmicas está associado a uma pequena taxa de desgaste em superfícies com rugosidades muito baixas, e em mecanismos de desgaste dominados por deformações plásticas ou por reações triboquímicas. Os "debris" resultantes do desgaste são claramente visíveis e podem ser diferentes do material de origem devido, por exemplo, à oxidação ou hidratação.

O desgaste severo está associado a uma alta taxa de desgaste com uma superfície que possuem uma alta rugosidade e um mecanismo de desgaste dominado por fratura frágil. Os "debris" resultantes do desgaste são geralmente angulares e não são quimicamente diferentes do substrato (SAHOO et al, 1998).

\subsection{PARÂMETROS DE USINAGEM}

De acordo com GE P.Q (2004), a eficiência do processo de corte com fio abrasivo aumenta com o aumento da tensão do fio, e que a eficiência é proporcional à tensão. No entanto, com o aumento da tensão, existe o encurtamento da vida do fio de corte. O aumento da velocidade de corte, também age positivamente na eficiência de corte bem como o tamanho do grão do abrasivo que age positivamente quanto maior for esse diâmetro.

Então para conseguir uma maior taxa de desgaste da cerâmica, é preciso utilizar o fio de corte na maior velocidade possível, aplicar a maior tração que o fio de corte agüentar e usar o maior grão de abrasivo disponível. 
O componente químico SiC (Carbeto de Silício) também chamado de carburundum (ASCANÊO, 2004), é formado por cristais extremamente duros, escuros e que são insolúveis em água e em outros solventes comuns. Esse componente, que é muito usado como abrasivo, pode ser encontrado também com o nome comercial Crystolon. Ele é resistente ao calor, decompondo-se em temperaturas próximas de $2700^{\circ} \mathrm{C}$ sendo utilizado em materiais refratários, tais como: varas, tubos, tijolos a prova de fogo e em partes especiais de reatores nucleares. O Carbeto de silício muito puro é normalmente branco ou não possui cor. Esses cristais são também usados na indústria de semicondutores para aplicações que requerem alta temperatura. Além disso, esses cristais também são usados como aditivos para plásticos ou metais leves, sendo responsável pelo aumento da força e rigidez dos mesmos.

\subsection{ESTIMATIVA DA TAXA DE DESGASTE NA USINAGEM POR ABRASÃO}

Existem 3 métodos disponíveis para estimar a taxa de desgaste (HUTCHINGS, 1992) e (LIPSON, 1967). O primeiro método, não muito útil, mede a taxa de desgaste de um equipamento já construído. Ainda para estimar a taxa de desgaste, é preciso tomar muito cuidado pois a taxa de desgaste em alguns sistemas não é constante, podendo cair ou aumentar depois de certo tempo.

O segundo método de estimar a taxa de desgaste obtém os dados de testes nos componentes do sistema, sob condições que simulam aquelas esperadas. Esse método é largamente usado para prever desgaste em rolamentos, o qual pode ser exposto em uma bancada de laboratório a condições de carga, velocidade, temperatura e diferentes condições de lubrificação simulando as condições em que o rolamento irá ser exposto. No entanto, se algum tipo de teste acelerado for usado, por exemplo, em um teste onde a velocidade de deslizamento for propositalmente aumentada para produzir um desgaste prematuro, deve-se ter muita cautela e ainda ter certeza de que o mecanismo de desgaste não foi mudado. 
Equações teóricas e empíricas relativas à taxa de desgaste e outras variáveis tais como a carga e a velocidade de deslizamento fornecem o terceiro meio de prever a taxa de desgaste. Equações simples relativas à taxa de desgaste, como por exemplo, a equação de Archard aplicada à abrasão e erosão.

Essas equações fornecem somente uma estimativa crua da taxa de desgaste, porém é uma maneira de estimar o valor do desgaste no início do projeto de um mecanismo de desgaste.

\subsection{CONDIÇÕES PARA O CORTE NA INTERFACE}

Manter as condições na interface é um dos aspectos mais importantes na usinagem com fio abrasivo, tanto no campo da usinagem, como no campo econômico (SHAW,1984). As funções relativas em se mergulhar o abrasivo em um líquido, como por exemplo a querosene, são as seguintes:

- Possuir ação abrasiva através de partículas sólidas contidas no líquido

- Remover o material que sofreu usinagem da interface, e fornecer o polimento da cerâmica através da ação abrasiva.

- Remover o calor gerado na usinagem.

O custo do abrasivo corresponde a algo entre 25 a 35 \% na fabricação de "wafers", então pode-se dizer que qualquer mudança positiva ou negativa nas condições da interface vai ter um impacto direto no preço final do "wafer".

Sabe-se que no processo de corte utilizando fio abrasivo , a fração de volume do abrasivo na interface diminui progressivamente com o andamento do processo, e em contra partida, o volume dos "debris" aumentam com o tempo do processo até ao ponto que não exista mais o abrasivo na interface.

Devido a esses fatores, a qualidade do corte vai decaindo com o passar do tempo de usinagem. Para manter um corte uniforme e com um excelente acabamento, é necessário manter a fração de volume do abrasivo e dos "debris" constante na 
interface. Em outras palavras, sejam $V_{f a}, V_{f c}$ e $V_{f d}$ as frações de volume do abrasivo, do corte feito na cerâmica e dos "debris" respectivamente, então:

$$
\begin{aligned}
& V_{f a}>V_{f c o} \\
& V_{f c}<V_{f k o}
\end{aligned}
$$

Onde $V_{f c o}$ e $V_{f k o}$ são a mínima e o máxima fração de volume do abrasivo e do corte na cerâmica respectivamente, mas:

$$
V_{f a}+V_{f c}+V_{f d}=1
$$

Então, isso passa a ser um problema em função do tempo, onde as seguintes características tem que ser obedecidas:

$$
\begin{aligned}
& V_{f c o}<V_{f a}<1 \\
& 0<V_{f c}<V_{f k o} \\
& 0<V_{f d}<1
\end{aligned}
$$

Os valores de $V_{f c o}$ e $V_{f k o}$ podem ser obtidos experimentalmente (SAHOO et al, 1998).

\subsection{Folga de corte entre o fio e a cerâmica}

Segundo Watanabe (2002), a folga de corte em um processo de corte com fio e abrasivos livres é igual a 3 vezes ao diâmetro médio do abrasivo utilizado. Isso se deve ao gradiente de velocidades como pode ser visto na Figura 4.11, que faz com 
que um grão de abrasivo role sobre outros grão de abrasivo, aumentando assim a folga.

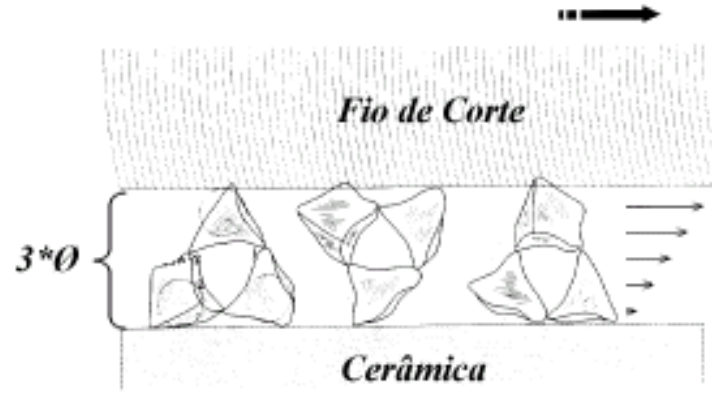

Figura 4.11-Folga de Corte do Processo 


\section{A EQUAÇÃO DE ARCHARD}

\subsection{INTRODUÇÃO}

Quando duas superfícies em contato deslizam uma sobre a outra, uma das duas ou as duas sofrerão desgaste. Uma análise simples desse tipo de desgaste deu origem à teoria de Holm e Archard (SINHA,2006).

Pela sua simplicidade, a equação de Archard evidencia as principais variáveis que influenciam o desgaste por deslizamento e também mostra um método de descrever a severidade do desgaste, através do coeficiente de desgaste $K_{n}$, o qual é reconhecido e amplamente utilizado. O modelo foi desenvolvido originalmente para metais, porém ele também pode fornecer pistas sobre desgaste em outros materiais, como, por exemplo, os materiais cerâmicos.

\subsection{O MODELO}

O modelo considera que o contato entre duas superfícies irá ocorrer onde houver contato entre asperezas, e que a área verdadeira de contato de duas superfícies será igual à soma do contato individual de todas as asperezas. Essa área será praticamente proporcional à força normal, e isso pode ser assumido na grande maioria das situações.

A Figura 5.1 mostra o contato de uma única aspereza, que assumiremos ter uma seção transversal circular de raio a. Na Figura 5.1 (b) ela terá atingido o seu tamanho máximo, e a carga normal suportada por ela $\delta W$, será dada por:

$$
\delta W=p \pi a^{2}
$$

onde $p$ será a pressão necessária para deformar plasticamente a aspereza, que será próximo à dureza $\mathrm{H}$. 
O deslizamento continua, as duas superfícies são deslocadas como mostrado nas Figura 5.1 (c) e (d), e a carga originalmente suportada por uma aspereza é progressivamente transferida para junções com outras asperezas que estão se formando em outras partes da superfície. Enquanto a superfície desliza, há contínua formação e destruição de contatos individuais entre asperezas. O desgaste está associado com o destacamento de fragmentos dos materiais das asperezas, e o volume de cada fragmento retirado do material irá depender diretamente do tamanho da junção de asperezas que esse fragmento se originou. Assumindo que o volume retirado de material por desgaste, $\delta V$, será proporcional ao cubo da dimensão do raio $a$, o que implica que a forma da partícula retirada deverá ser independente do seu tamanho.

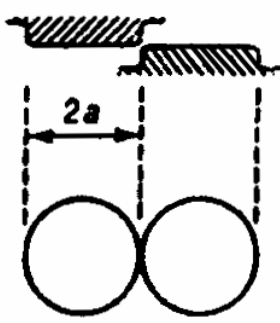

(a)

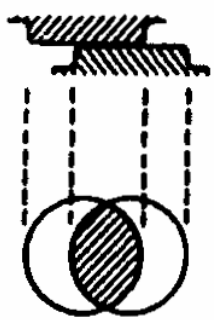

(b)

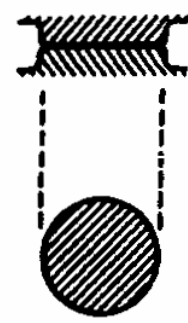

(c)

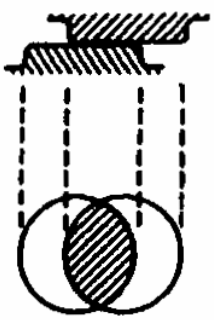

(d)

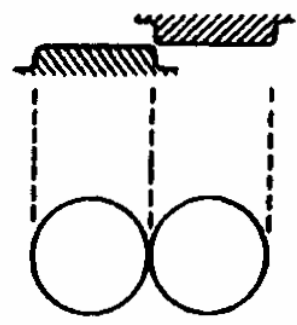

(e)

Figura 5.1 - Interação entre asperezas

Pode-se calcular o volume supondo que as asperezas são hemisférios com raio $a$, assim o volume do material retirado por desgaste é dado por:

$$
\delta V=\frac{2 \pi a^{3}}{3}
$$

Nem todas as asperezas possuem altura suficiente para entrar em contato com as asperezas de uma outra superfície em deslizamento.Então supõem-se que somente uma porção $\kappa$ será capaz de interagir. Então vamos calcular a média de material destacado $\delta Q$ por unidade de distância de deslizamento. É sabido que o volume da aspereza, e a distância que ela ocupa; além disso, é levado em conta a probabilidade de haver colisão entre asperezas assim: 


$$
\delta Q=\frac{\kappa \delta V}{2 a}=\frac{\kappa \pi a^{2}}{3}
$$

Então a taxa de desgaste total $Q$ resultante da soma do contato de todas as asperezas da área real de contato é denominado por:

$$
Q=\sum \delta Q=\frac{\kappa}{3} \sum \pi a^{2}
$$

A carga normal $W$ é dada por:

$$
W=\sum \delta W=P \sum \pi a^{2}
$$

assim:

$$
Q=\frac{\kappa W}{3 P}
$$

É conveniente combinar o fator $1 / 3$ na constante de proporcionalidade, assumindo $K=\kappa / 3$, e ainda assumir que $P=H$. Então, pode-se reescrever a equação acima na seguinte forma:

$$
Q=\frac{K W}{H}
$$

Essa equação que relaciona o volume total de material desgastado $Q$, a carga normal aplicada $W$, e a dureza do material mais mole $H$ (RATTIKORN et al., 2004) e (PRAMOD et al., 2001) é conhecida como a equação de desgaste de Archard. A constante $K$, também chamada de coeficiente de desgaste, é adimensional e possui sempre valor menor que 1.

A equação acima implica que se $K$ é constante para um dado sistema deslizante, então o volume de material perdido será proporcional à distância percorrida pelo 
deslizamento, e se a carga normal $W$ variar, então o desgaste deverá variar proporcionalmente.

\subsection{VARIÁVEIS QUE INFLUEM NO CORTE DA CERÂMICA}

Analisando todas as variáveis que podem influenciar o corte da cerâmica, as seguintes variáveis foram escolhidas por serem de uma grande influência e ainda possuírem certa facilidade de serem manipuladas para atingir os objetivos desejados. As variáveis são as seguintes:

- Velocidade tangencial relativa do fio

- $\quad$ Abrasão a 2 ou 3 Corpos

- $\quad$ Tensão Normal aplicado ao fio

- $\quad$ Tensão de corte aplicada a cerâmica

- $\quad$ Tamanho do grão do abrasivo

- $\quad$ Tipo de fluido de Corte

- $\quad$ Ambiente (Reação triboquímica)

Algumas das variáveis acima não estão relacionadas com a mecânica da máquina e sim com componentes externos, tais como o fluido de corte, tamanho de grão do abrasivo, tipo de abrasão e a reação química do ambiente. Para atingir resultados melhores, de preferência a máquina deverá ficar em um ambiente controlado, com a escolha dos componentes de cortes adequados. 


\section{PROCEDIMENTO EXPERIMENTAL}

\subsection{RESULTADOS}

\subsubsection{INTRODUÇÃO}

Este capítulo trará os resultados dos experimentos, que respeitaram os limites físicos da máquina construída, bem como previsões de modificações que fará com que ela tenha um funcionamento ainda melhor no futuro.

Os experimentos consistem em usinar um canal de $1 \mathrm{~mm}$ de profundidade e $35 \mathrm{~mm}$ de comprimento, sob diferentes parâmetros de usinagem, a fim de se medir o tempo com que o objetivo é cumprido.

\subsection{EXPERIMENTOS}

\subsubsection{Experimento 1}

O experimento 1 consiste em realizar o corte na cerâmica sob diferentes velocidades tangenciais do fio de corte para que seja possível visualizar a influência da velocidade do fio do corte no tempo de usinagem da cerâmica. Os parâmetros de corte que foram usados foram:

Granulação do Abrasivo: 1200

Freqüência de mudança do sentido do Fio: $2 \mathrm{~Hz}$ 
Tempo de Usinagem $x$ Velocidade Tangencial do Fio

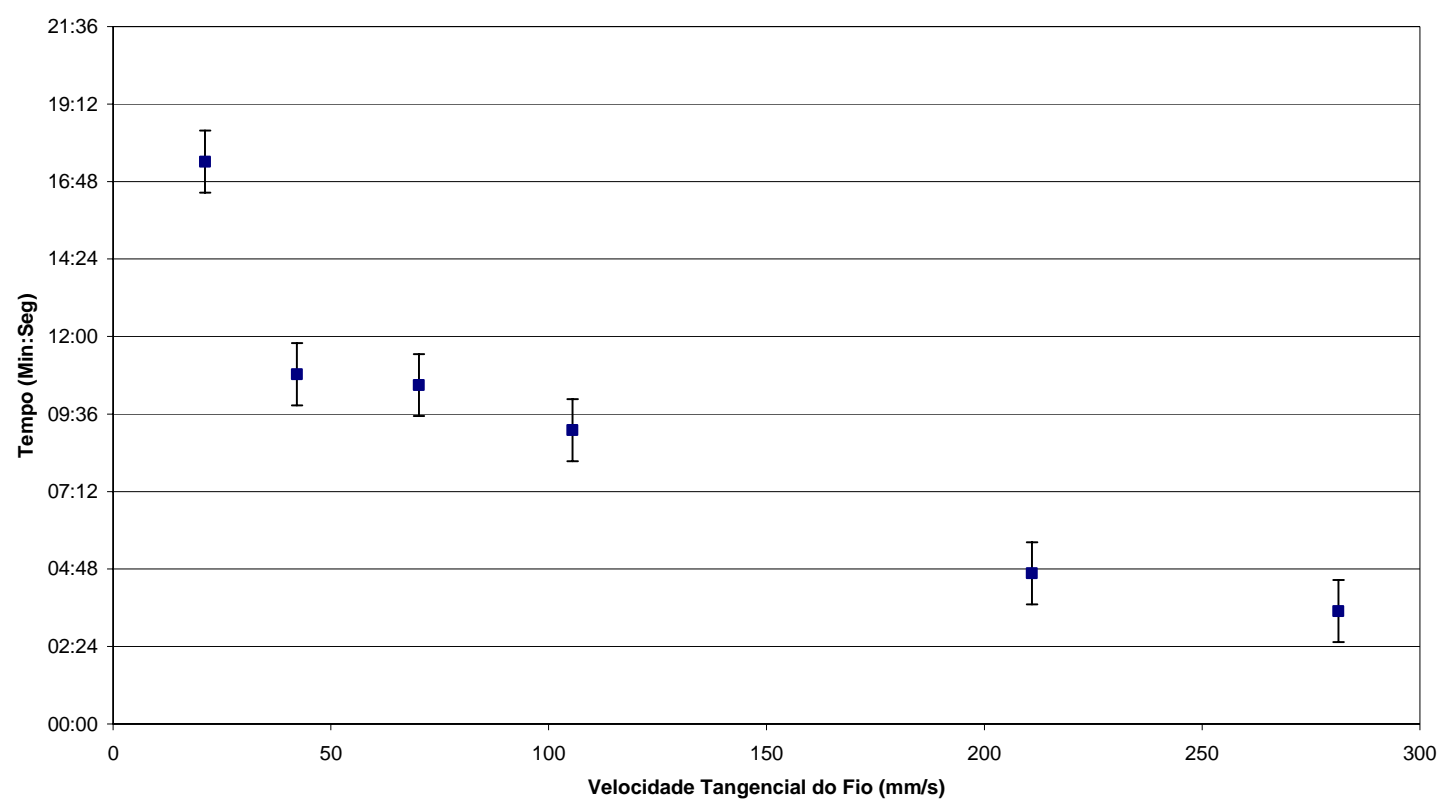

Figura 6.1 - Gráfico do tempo de usinagem x velocidade tangencial do fio de corte

O experimento 1 demonstrou que existe uma forte dependência entre a velocidade tangencial do fio de corte e o tempo de usinagem. Isso já havia sido previsto pela teoria na Figura 4.9 na transição entre desgaste brando e desgaste severo. No caso do experimento 1 pode-se enxergar uma certa linearidade no gráfico da figura 6.1, o que não nos permite ainda dizer se está sendo trabalhado na região de desgaste brando ou severo, e o mecanismo de corte não tem a capacidade de alcançar maiores velocidade para responder a essa pergunta devido a tensão utilizada para alimentar os driveres, no entanto o valor mínimo alcançado de tempo de usinagem já é satisfatório.

\subsubsection{Experimento 2}

O experimento 2 consiste em realizar o corte na cerâmica sob diferentes freqüências de mudança de sentido do fio, mantendo-se todas as outras variáveis constantes a fim de que se determine a influência dessa freqüência de mudança de sentido do fio na usinagem da cerâmica. Os parâmetros de corte que foram usados foram: 
Granulação do Abrasivo: 1200

Velocidade Tangencial do Fio: 200 mm/s

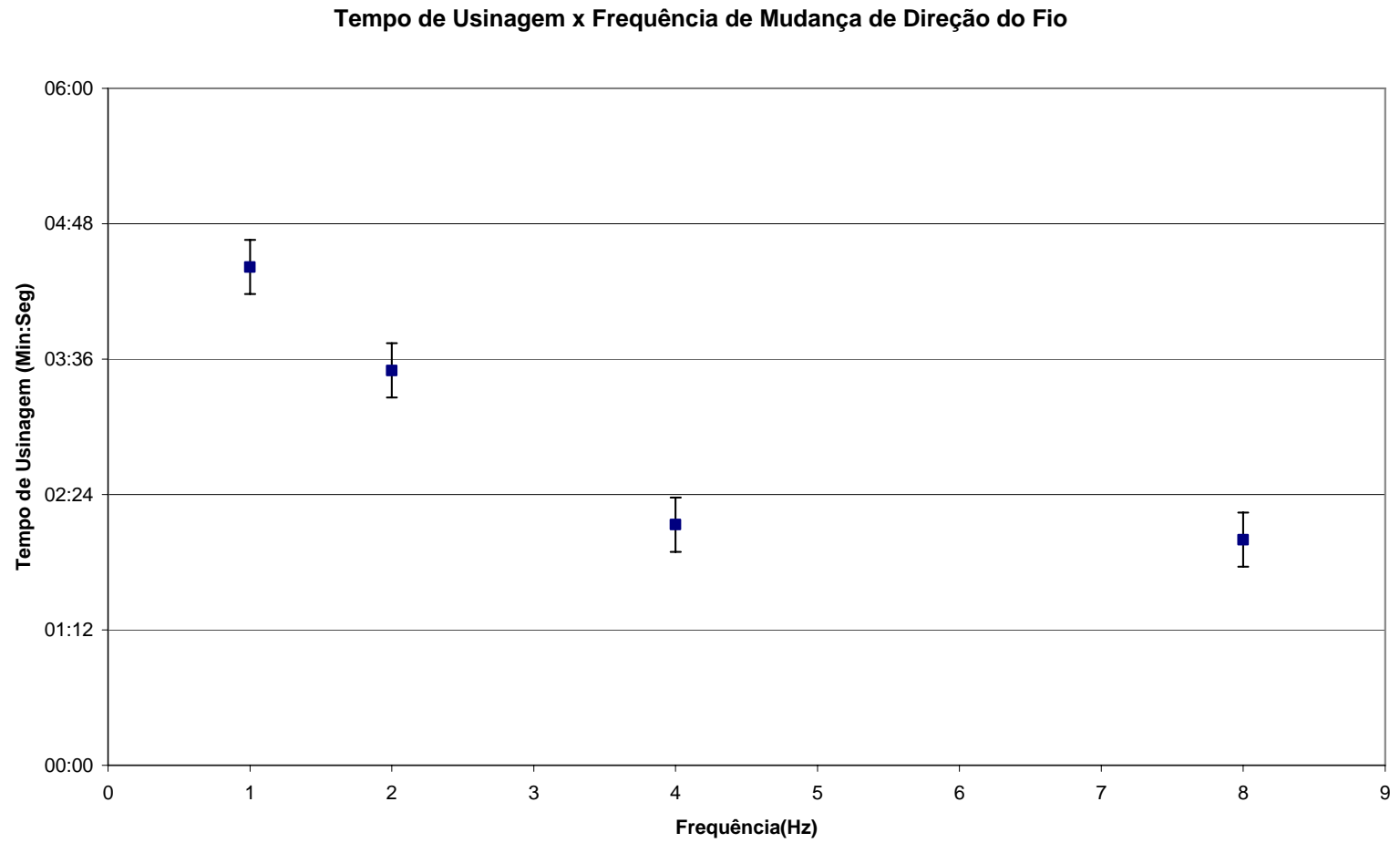

Figura 6.2 - Gráfico do tempo de usinagem x freqüência de mudança de direção do fio de corte

O experimento 2 demonstrou que existe também uma forte dependência entre o tempo de usinagem e a freqüência da mudança da direção do fio de corte. Isso se deve basicamente ao aparecimento de novas arestas de corte quando há a mudança de direção de corte do fio abrasivo, pois quando não há mudança de direção de corte, a topografia do canal que está sendo usinado na cerâmica possui características mais arredondadas o que diminui e muito a taxa de desgaste no sistema. Então de acordo com o gráfico da Figura 6.2, pode-se seguramente afirmar que para uma freqüência de mudança de direção entre 4 e $8 \mathrm{~Hz}$, as arestas de cortes continuaram afiadas, mantendo-se assim a taxa de desgaste do sistema em questão elevada. 


\subsubsection{Experimento 3}

O experimento 3 consiste em realizar o corte na cerâmica sob o uso de diferentes tipos de tamanhos de granulações do abrasivo para que se possa aferir a influência do tamanho do grão do abrasivo na usinagem da cerâmica pelo método de usinagem estudado. Os parâmetros de corte que foram usados foram:

Velocidade Tangencial do Fio: $200 \mathrm{~mm} / \mathrm{s}$

Freqüência de mudança do sentido do Fio: $2 \mathrm{~Hz}$

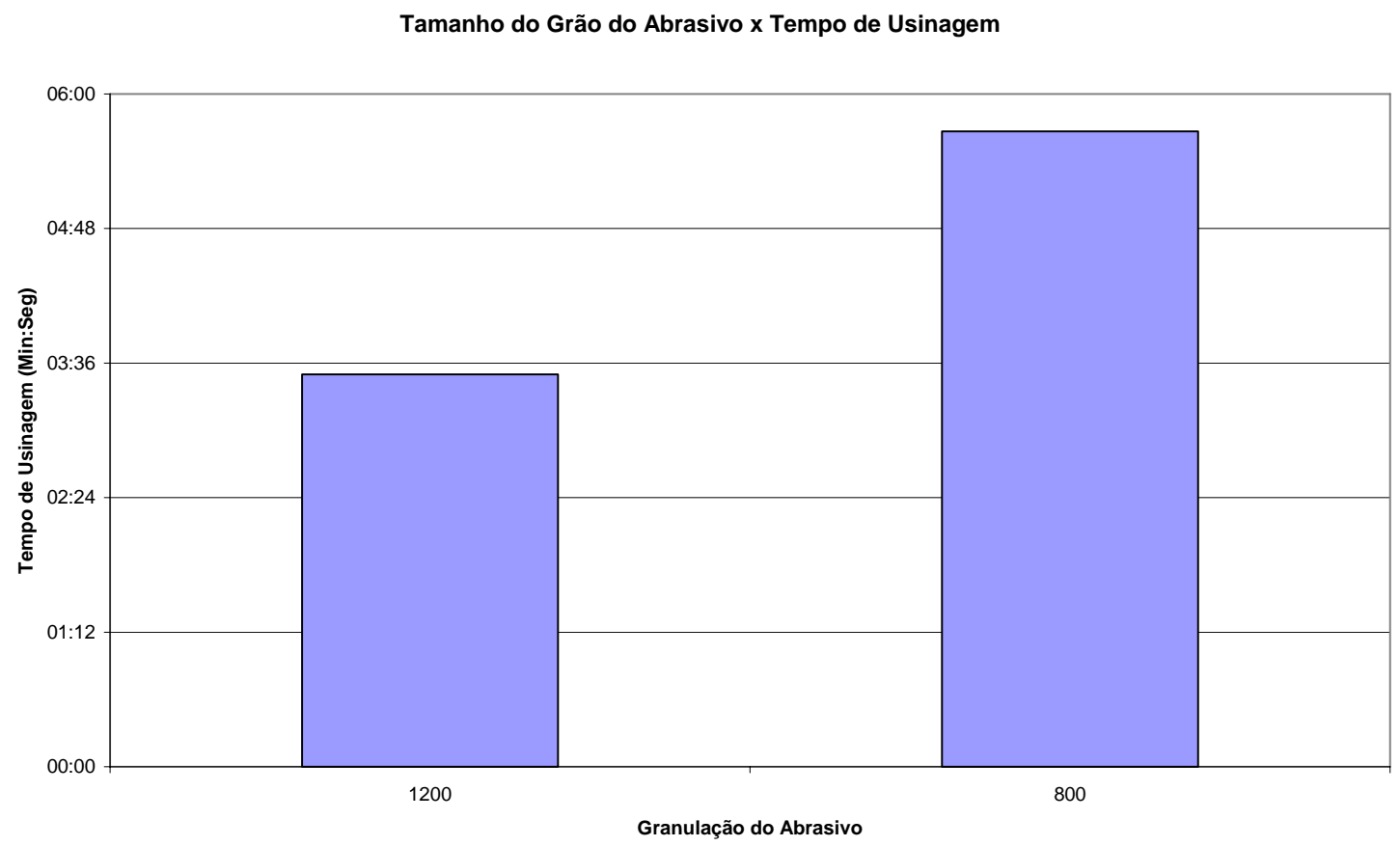

Figura 6.3- Gráfico da Relação do Tamanho do Grão do Abrasivo x Tempo de Usinagem

O experimento 3 demonstrou que existe também uma forte dependência entre o tamanho da granulação do abrasivo e o tempo de usinagem. No entanto esse experimento não foi condizente com a teoria como é demonstrado nas Figura 4.7 e Figura 4.8, pois nesse experimento uma granulação menor do abrasivo (1200) obteve um tempo de usinagem melhor que um abrasivo com uma granulação maior (800). Essa discrepância pode ser explicada devido à natureza do desgaste envolvido. Para um desgaste onde existem duas superfícies amplas em contato com abrasivo na interface, a teoria das Figura 4.7 e Figura 4.8 são válidas, no entanto 
para um local onde há desgaste entre um canal em uma cerâmica um pouco maior de 0,14 mm de largura e um fio de corte de 0,14 mm de diâmetro, com certeza um abrasivo maior irá encontrar certa dificuldade de nucleação na interface. Talvez por isso o abrasivo com granulação menor obteve melhores resultados.

\subsubsection{Experimento 4}

O experimento 4 consiste em se determinar a relação entre o desgaste do fio de corte e o número de vezes que uma mesma secção do mesmo é utilizado para se usinar a cerâmica. Os parâmetros de corte que foram usados foram:

Granulação do Abrasivo: 1200

Freqüência de mudança do sentido do Fio: $2 \mathrm{~Hz}$

Velocidade Tangencial do Fio: 200 mm/s

Desgaste do Fio de Corte

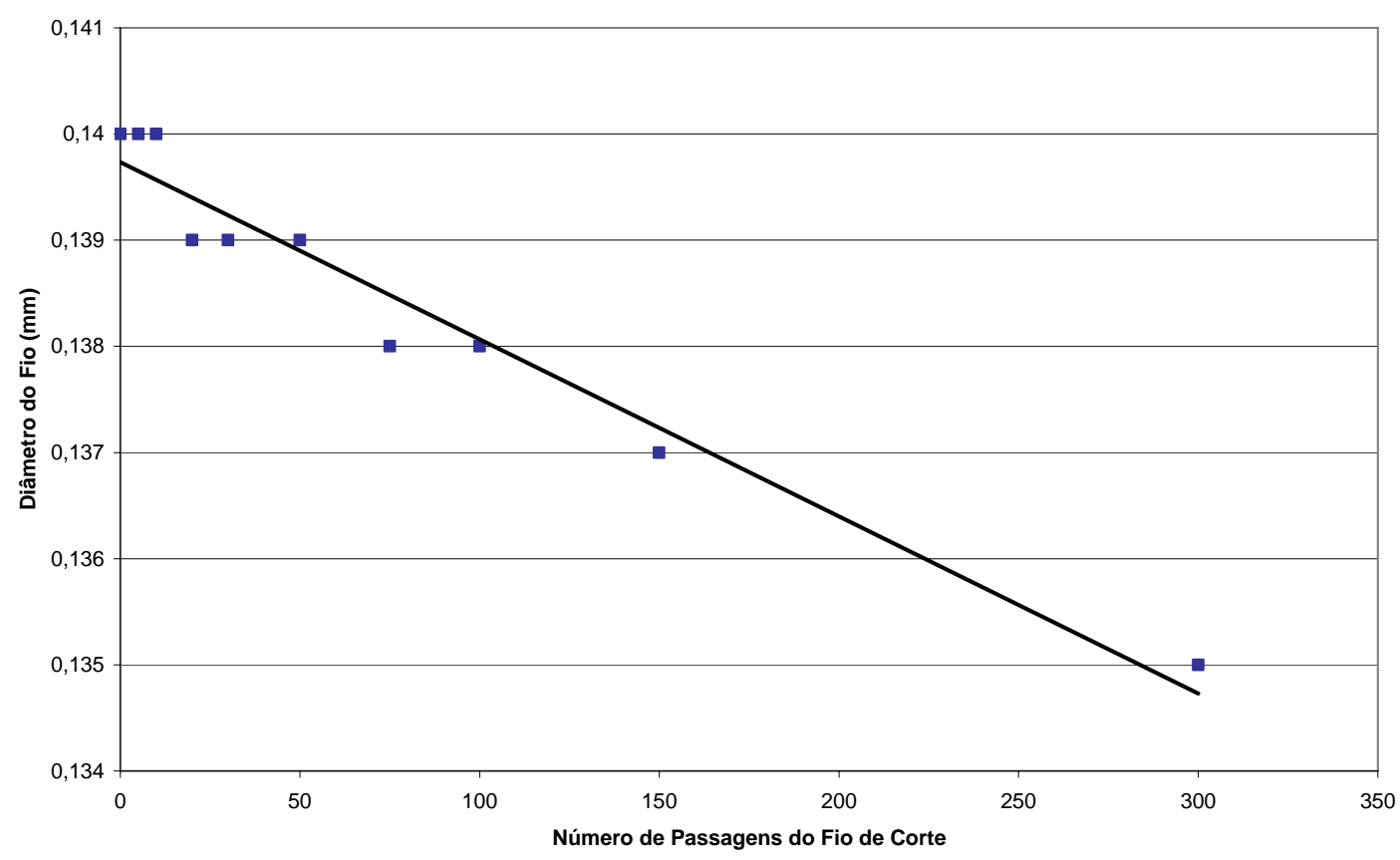

Figura 6.4 - Gráfico do diâmetro do fio de corte x número de reutilizações do fio 
Como pode ser visto no gráfico da Figura 6.4, o fio de aço inoxidável utilizada como fio de corte possui alta resistência ao desgaste no sistema de corte e pode ser reutilizado diversas vezes sem prejuízo da usinagem da cerâmica, no entanto um valor próximo a 50 vezes será utilizado como valor final, por questões de segurança.

\subsection{PROCEDIMENTO EXPERIMENTAL}

\subsubsection{INTRODUÇÃO}

Um dos objetivos dessa dissertação é encontrar uma maneira rápida de se fazer a usinagem na cerâmica pelo método proposto. Assim foi elaborado o seguinte procedimento experimental para usinar um transdutor piezelétrico compósito protótipo.

A Figura 6.5 mostra as características geométricas da cerâmica que será usada para a confecção do protótipo. Ela possui diâmetro externo de $38 \mathrm{~mm}$ e diâmetro interno de $12,5 \mathrm{~mm}$, e altura de $6,4 \mathrm{~mm}$.
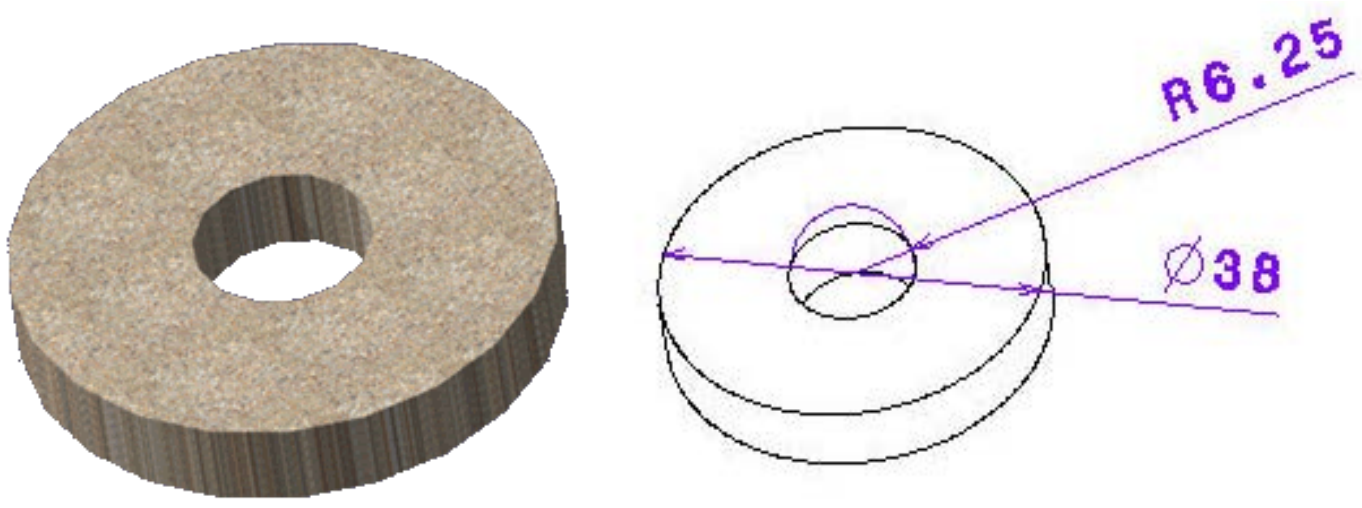

Figura 6.5 - Desenho da cerâmica a ser usada no procedimento

As características geométricas de como deve ficar o protótipo depois de finalizado são mostrados na Figura 6.6. 

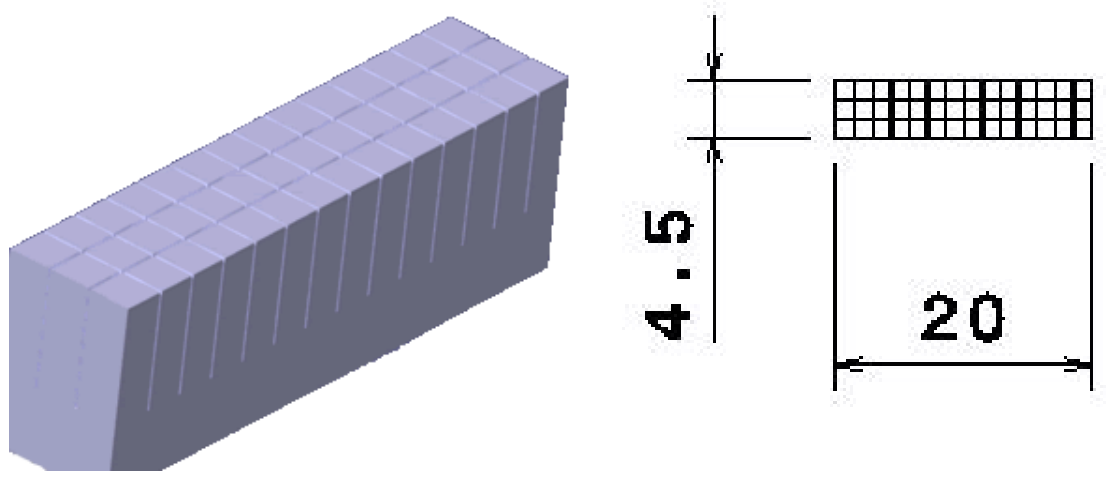

Figura 6.6 - Resultado do procedimento de corte

A cerâmica depois de usinada terá dimensões de $20 \mathrm{~mm} \times 4,5 \mathrm{~mm}$, e os cortes terão profundidade de cerca de $3 \mathrm{~mm}$ e ocorrem em um passo de aproximadamente 1,5 $\mathrm{mm}$. A Figura 6.7 mostra comparativamente onde vai ser feita a usinagem.

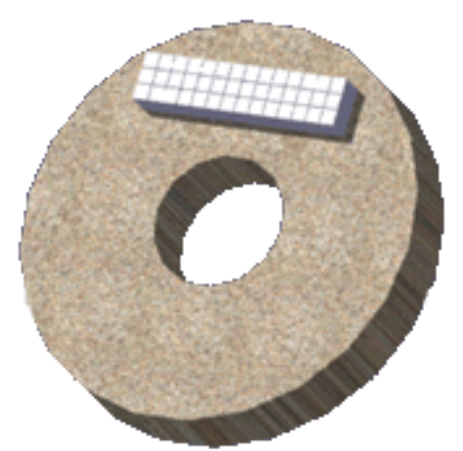

Figura 6.7 - Localização dos cortes na cerâmica

Como pode ser visto na Figura 6.7, a área onde se tem que usinar é muito menor que a área total da cerâmica, por isso foi elaborada uma seqüência de corte de acordo com a Figura 6.8, a fim de que se diminua consistentemente o tempo de usinagem. 


\subsubsection{SEQUÊNCIA DE CORTE}

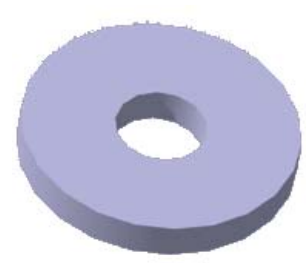

(A)

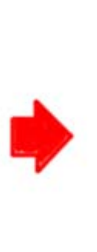

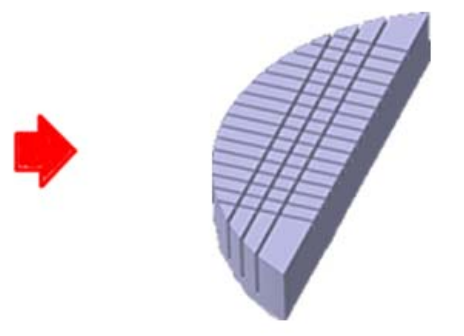

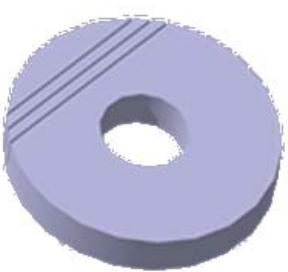

(B)

\section{(D)}

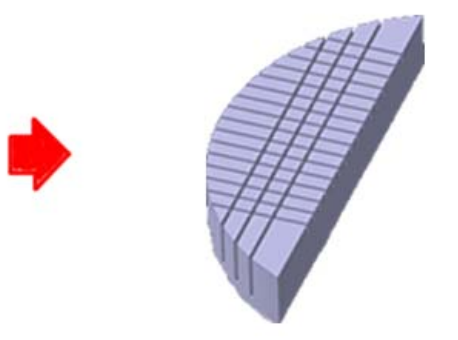

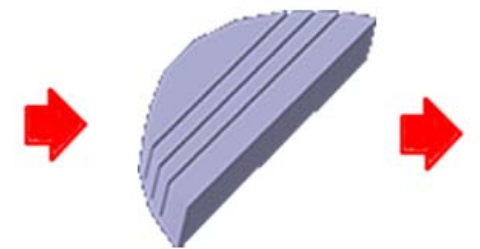

(C)

Figura 6.8 - Seqüência de corte da cerâmica

A seqüência de corte elaborada consiste primeiramente em se fazer os cortes desejados na direção onde existem menos cortes a se fazer. A seguir, deve-se cortar até o fim a parte da cerâmica onde não vai haver uso (Figura $6.8 \mathrm{C}$ ), pois isso irá diminuir sensivelmente a superfície a ser cortada na direção onde existe a maior quantidade de cortes a serem feitos e com isso vai haver um ganho substancial de tempo. Para finalizar deve-se rotacionar a cerâmica de $90^{\circ}$ e fazer normalmente os cortes restantes.

Um outro fator interessante é que na usinagem dos canais, estes ficaram com uma profundidade de pelo menos $3 \mathrm{~mm}$, dos 6,4 $\mathrm{mm}$ possíveis, isso se deve ao fato de manter um ângulo de inclinação elevado entre o fio de corte e a cerâmica a fim de acelerar o corte, já que se o fio ficar praticamente paralelo ao plano horizontal, a força de corte será muito pequena. 


\subsubsection{USINAGEM DA CERÂMICA}

A Figura 6.9 que mostra o desgaste da cerâmica em várias etapas em uma determinada seção transversal, assim pode-se ver que o desgaste na cerâmica não se da de forma uniforme. Primeiramente ocorre o desgaste das áreas mais periféricas e com o desgaste dessas áreas, as partes mais centrais dão maior sustentação ao fio que acaba por desgastar mais essa região. Esse desgaste continua até que o ângulo formado pelo fio de corte com a linha horizontal seja aproximadamente zero. Nesse momento, o desgaste na cerâmica passa a ser aproximandamente nulo, e a usinagem de um canal estará pronta.

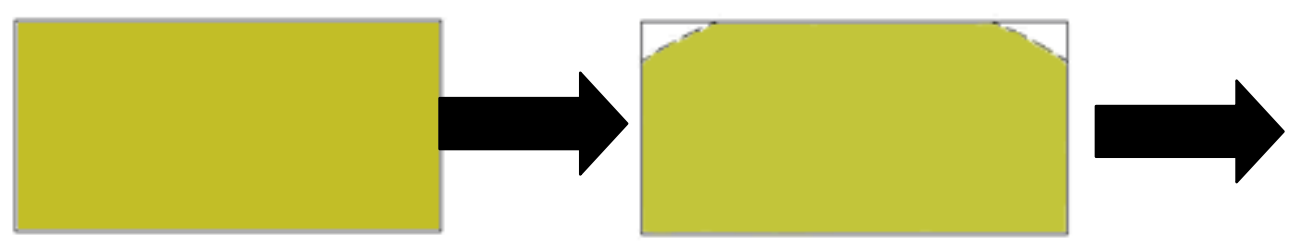

(A)

(B)

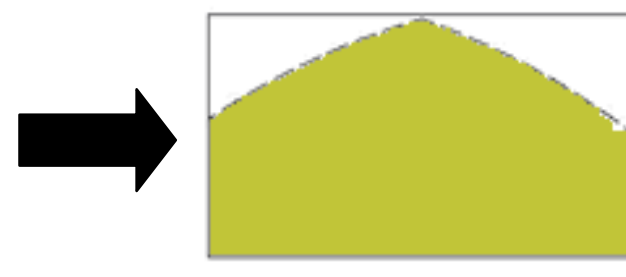

(C)

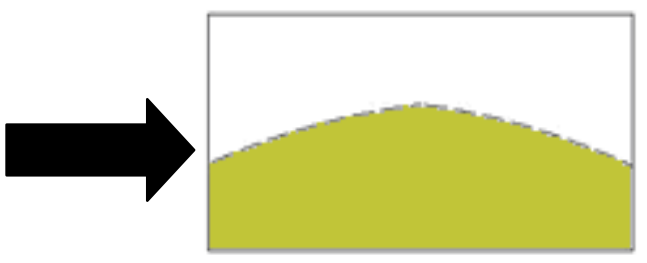

(D)

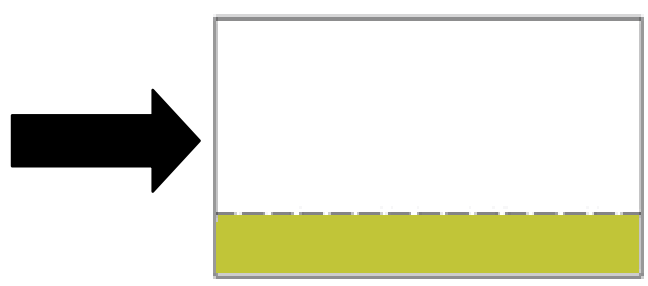

(E)

Figura 6.9 - Processo de usinagem do canal na cerâmica

Uma característica interessante é que a taxa de desgaste varia com o ângulo do fio, ou seja, a tensão aplicada pelo fio na cerâmica varia com o ângulo de ataque do mesmo, então no caso da Figura 6.9 (E), onde a superfície de corte é praticamente 
paralela ao fio de corte, pode-se dizer que a taxa de desgaste é nula, já na Figura 6.9 (B), onde o corte começa a ser feito e o ângulo de ataque é máximo pode-se dizer a taxa de desgaste é máxima.

\subsubsection{PROCEDIMENTO PARA O CORTE}

Primeiramente, deve-se verificar se a mesa onde ocorre o movimento horizontal está perfeitamente alinhada ao eixo. Isso é feito através de um relógio comparador. Caso ela não esteja, calços devem ser providenciados a fim de manter o paralelismo da máquina. Esse paralelismo é importante a fim de se conseguir realizar cortes perpendiculares à base da cerâmica.

Depois de verificar o paralelismo da mesa, é necessário fixar a cerâmica que será cortada. Essa fixação é feita através de uma massa epóxi (araldite), que não é dissolvida pelo fluido de corte utilizado que no caso é o querosene por ele ser um fluido apolar.

Após realizar a fixação, deve-se levar a máquina até o fim de curso com a finalidade de se ter uma referência dos dois eixos, com isso tem-se a capacidade de posicionar com precisão o ponto inicial de corte.

Ao se posicionar o fio de corte sobre uma área onde nenhum corte foi feito anteriormente, deve-se manter um ângulo de deflexão do fio (ângulo entre o fio e o horizonte) praticamente inalterado, para a formação de um trilho que servirá de guia para o fio. Caso essa etapa não seja cumprida, corre-se o risco de o fio sair de posição devido a qualquer desnivelamento da cerâmica em relação ao horizonte e também graças a baixa rigidez do fio de corte. 


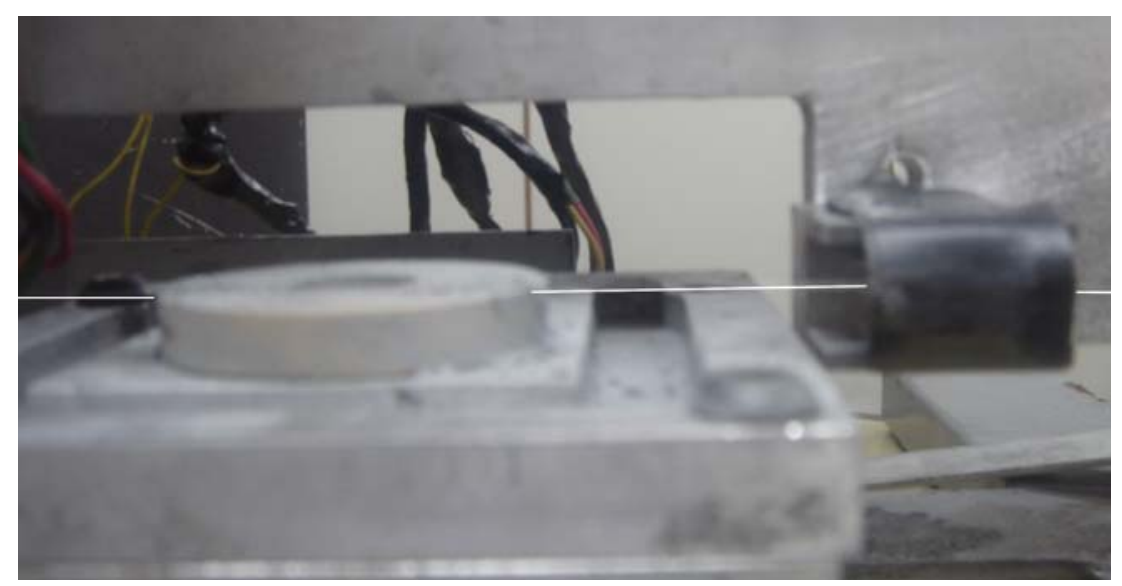

Figura 6.10 - Fio de corte paralelo

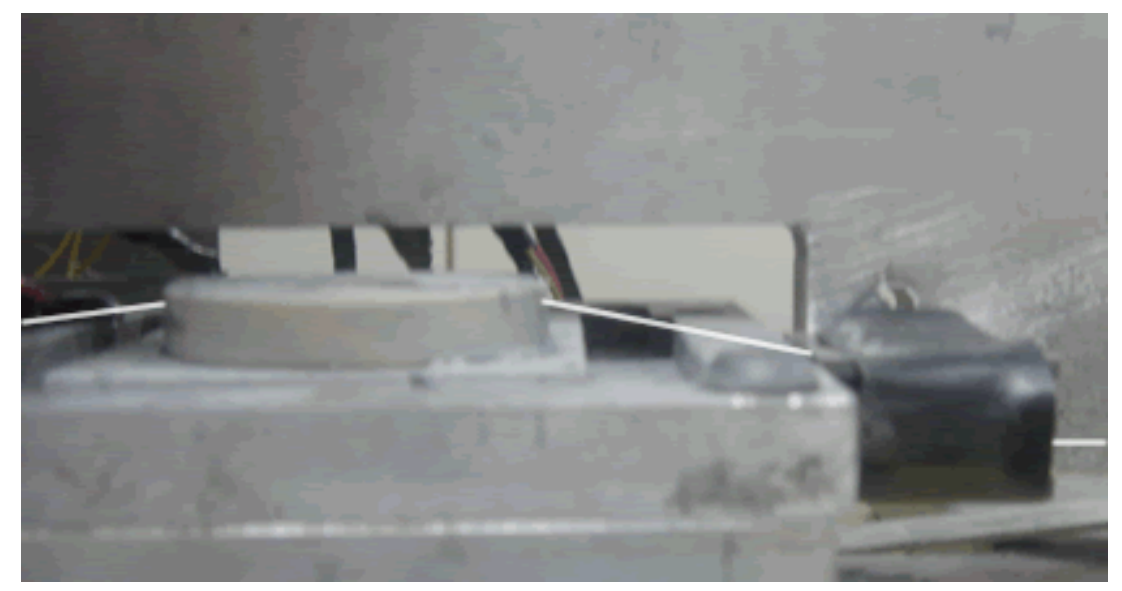

Figura 6.11- Ângulo de ataque do fio para aumento da taxa de remoção de material

Após a formação do trilho, deve-se aumentar o máximo possível esse ângulo, a fim de se acelerar a remoção do material. A profundidade de corte é medida parando-se a máquina e deixando novamente o fio de corte em posição horizontal e encostado na cerâmica. Assim é possível ver a profundidade de corte atingida no visor LCD. Depois de se ter atingido a profundidade de corte desejada, deve-se posicionar o fio de corte para o próximo corte e assim fazer quantos cortes desejar com essa orientação.

Após realizar os cortes em uma direção, deve-se rotacionar a cerâmica de $90^{\circ}$, e continuar o mesmo procedimento a fim de formar os pilares. Não é recomendável o uso da resina para aumentar a resistência das colunas antes da rotação da cerâmica, pois a resina além de aumentar o volume a ser cortado, desnivela grosseiramente a referência em relação ao eixo horizontal da cerâmica. 


\subsubsection{PRIMEIRO RESULTADO DO CORTE EXPERIMENTAL}

A Figura 6.12 mostra o primeiro resultado prático que foi conseguido através do planejamento que foi explanado durante esse capítulo. Existem ainda nesse protótipo de cerâmica piezocompósito algumas falhas de usinagem inerentes ao processo de experimentação e que foram corrigidas com o ganho de experiência do operador do dispositivo de corte.

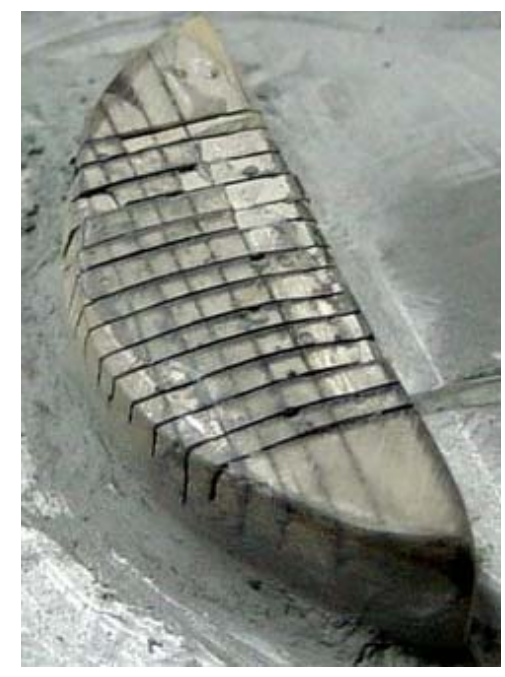

Figura 6.12- Foto do primeiro protótipo feito no mecanismo de corte 


\section{CONCLUSÕES E SUGESTÕES PARA TRABALHOS FUTUROS}

\subsection{CONCLUSÕES}

Após fazer todo o estudo teórico, a construção prática do mecanismo de corte, a criação de um procedimento experimental e a realização de tais procedimentos, conseguiu-se chegar ao objetivo final dessa dissertação que era estabelecer parâmetros ótimos de corte para confecção de cerâmicas piezocompósitos. Assim, a Tabela 7.1 traz esses parâmetros que foram baseados nos resultados mostrados no Capítulo 6 , dessa dissertação.

Tabela 7.1 - Parâmetros de Regulagem do Mecanismo de Corte

\begin{tabular}{|c|c|}
\hline Parâmetros & Valor \\
\hline $\begin{array}{c}\text { Tamanho do } \\
\text { Abrasivo } \\
\text { (Carborundum) }\end{array}$ & 1200 \\
\hline $\begin{array}{c}\text { Velocidade } \\
\text { Tangencial de } \\
\text { Corte }\end{array}$ & $275 \mathrm{~mm} / \mathrm{s}$ \\
\hline $\begin{array}{c}\text { Freqüência de } \\
\text { Mudança de } \\
\text { Direção }\end{array}$ & $6 \mathrm{~Hz}$ \\
\hline $\begin{array}{c}\text { Número de } \\
\text { Reutilizações do } \\
\text { Fio }\end{array}$ & 50 Vezes \\
\hline
\end{tabular}

Como pode ser visto na primeira linha da Tabela 7.1, o tamanho do abrasivo escolhido foi o de 1200, que é o menor entre os dois tipos testados, e isso não era esperado de acordo com o modelo de Archard e as experiências descritas em Hutchings (2002) e , que dizem que quanto maior for o grão do abrasivo, maior será a taxa de desgaste.Esse resultado se deve ao fato de abrasivos com maiores diâmetros possuírem a tendência de rolarem para fora da interface mais facilmente, assim as condições na interface não se mantiveram constantes.

A Tabela 7.1 na segunda linha, mostra que a velocidade de corte ideal para o mecanismo de corte é a velocidade máxima testada. Isso concorda com o modelo de 
Archard e as experiências descritas em Hutchings (2002) e Marinescu(2004), que dizem que quanto maior a velocidade tangencial de corte, maior será a taxa de desgaste.

A terceira linha da Tabela 7.1, mostra que uma mudança de direção da ordem de 6 $\mathrm{Hz}$ no fio de corte, é onde ocorreu a maior taxa de desgaste da cerâmica. de acordo com o experimento da Figura 6.2 - Gráfico do tempo de usinagem x freqüência de mudança de direção do fio de corteFigura 6.2. Essa informação está de acordo com as experiência contidas em Hutchings (2002) e Willian (2003), pois com esse movimento de oscilação aumenta a área onde o fio está em contato com a cerâmica e ainda faz com que a superfície de corte fique com um relevo favorável à retirada de material. O limite de $6 \mathrm{~Hz}$ foi encontrado nesse caso, pois acima desse valor, entra-se no regime de ressonância do tensionador e do fio.

A última linha da Tabela 7.1 mostra que nas experiências que foram feitas, o mesmo segmento de fio de corte foi reutilizado 50 vezes. Um valor maior poderia ser utilizado, porém de acordo com Watanabe (2002), é preciso manter as condições de corte constantes, ou seja, o volume de abrasivo na interface sempre tem que ser maior que o volume de "debris" na interface para a taxa de desgaste permanecer constante. Isso é conseguido através do uso de um novo segmento de fio, que faz com que os "debris" sejam expulsos da interface. 


\subsection{SUGESTÕES PARA TRABALHOS FUTUROS}

Esse mecanismo de corte consegue atender as necessidades de quem quer fabricar uma cerâmica piezocompósito, no entanto após realizar todo esse estudo existem claramente alguns pontos que podem ser estudos com mais rigor, tais como:

- Utilizar um fio de corte que já contenha o abrasivo preso rigidamente nele através do processo galvânico com níquel e diamante.

- Estudar a influência da distância entre as guias de safira e a taxa de desgaste da cerâmica, pois isso faria com que o ângulo de ataque do fio de corte fosse muito maior, aumentando assim as taxas de desgaste da cerâmica.

- Estudar o aumento da taxa de mudança de direção do fio na taxa de desgaste da cerâmica, pois nesse estudo esse valor foi limitado à $6 \mathrm{~Hz}$ devido as freqüências de ressonância do fio e do tensionador. 


\section{REFERÊNCIAS BIBLIOGRÁFICAS}

ANNIBAL, H. JR., "Computação Gráfica”, 1ª Edição,LTC Editora, 2006

ASCANÊO, W. M. "Projeto e fabricação de uma máquina de corte de cerâmica piezelétrica", Trabalho de formatura , São Paulo - Brasil, Escola Politécnica da Universidade de São Paulo, 2003.

BLITZ, J. "Fundamentals of ultrasonics" London - UK, Butterworths 1967.

BRIZZOTTI, M. A., "Análise de Materiais Piezelétricos Compósitos para Aplicações em Transdutores de Ultra-som" , Dissertação de Mestrado, São Paulo - Brasil, Escola Politécnica da Universidade de São Paulo, 2006.

DUNLAP Jr, W. L., 2004, "Recent Advences in Piezocomposite Material for Ultrasonic Transducers", 16th World Conference on Nondestructive Testing,Montreal.

EFRAT, U., 1993, "Optimizing the Wafer Dicing Process", Int'l IEEE/CHMT Electronics Manufacturing Technology Symposium, pp. 245-253.

GALLEGO-JUÁREZ, J. A., 1989, "Piezoelectric Ceramics and Ultrasonic Transducers", J. Phys. E: Sci. Instrum., 22, pp. 804-816.

GATZEN, H. H., 2001, "Dicing Challenges in Microelectronics and Micro ElectroMechanical Systems (MENS)", Microsystem Technologies, pp. 151-154.

GE P.Q, ZHANG, GAO W., LIU Z.C., "Development of Endless Diamond Wire Saw and Sawing Experiments", Advances in Materials Manufacturing Science and Technology, p. 481-484, 2004

HUTCHINGS, I. M., "Tribology: Friction and Wear of Engineering Materials", London - UK, Edward Arnold, 1992.

JIANG, J.; SONG, C.; ZHANG, Z., 2003, "Dicing Technology in Super-Thin Wafer for IC", IEEE, pp. 130-132. 
KALPAKJIAN, S., Schmid R. S. " Manufacturing Engineering and Technology", New Jersey - US,Prentice Hall 1998.

Kuttruff,H. "Ultrasonics - Fundamentals and Applications", Aachen, Alemanha, Elsevier Applied Science,1991

LIPSON, C. "Wear considerations in design", Englewood Cliffs - US, Prentice Hall 1967.

MAMALIS, A. G.; KUNDRAK, J.; GYANI, K.; HORVATH, M., 2002, " On the Precision Grinding of Advanced Ceramics", Int. J. Adv. Manuf. Technol., no. 20, pp. 255-258.

MARINESCU I. D., ROWE W. B., DIMITROV B., INASAKI I. "Tribology of abrasive machining processes". New York - US, William Andrew Inc 2004.

NADER, G., "Desenvolvimento de Técnicas de Caracterização de Transdutores Piezelétricos", Tese de Doutorado, São Paulo - Brasil, Escola Politécnica da Universidade de São Paulo, 2002.

NORTON L. R., “ Design of machinery”, Massachusetts - US, Mc Graw Hill 2001.

OGATA K., "Engenharia de Controle Moderno", Minnesota - US,Ltc Editora 1997.

PAPADAKIS, E. P.; OAKLEY, C. G.; SELFRIDGE, A. R.; MAXFIELD, B., 1999,"Fabrication and Characterization of Transducers" Physical Acoustics, vol.24.

PAZOL, B. G., Bowen, L. J., Gentilman, R. L., Pham, H. T., Serwatka, W. J., "Ultrafine Scale Piezoelectric Composite Materials for High Frequency Ultrasonic Imaging Arrays", 1995 IEEE Ultrasonics Symposium Proceedings, p. 1263-1268, 1995.

PRAMOD K. Sharma, Z. Ounaies, V. V. Varadan and V. K. Varadan, "Dielectric and piezoelectric properties of microwave sintered PZT",Smart Materials and Structures Electronic Journal, 2001.

RATTIKORN Y., Ekarat M., Supon A. e Tawee T. "Mechanical Properties of XPMN(1-x)PZT Ceramic Systems", CMU. Journal (2004)147-154. 
SAHOO R. K., V. Prasad, I. Kao, J. Talbott, K.P. Kupta, "Towards an Integrated Approach for Analysis and Design of Wafer Slicing by a Wire Saw", Journal of Electronic Packaging(1998) 35-40

SAVACUS, H. P., Klicker, K.A., Newnham, R. E., "PZT- Epoxy Piezoelectric Transducers: A Simplified Fabrication Procedure", Materials Research Bulletin, V. 16, p. 667-680, 1981.

SETO, W. W. "Vibrações Mecânicas", Rio de Janeiro,Ed. Mcgraw-Hill, 1972

SHAW M.C., "Metal Cutting Principles" New York, Oxford University Press, 1984.

SHIKATA, F. M."Transdutor piezelétrico de ultra-som", Trabalho de formatura , São Paulo - Brasil, Escola Politécnica da Universidade de São Paulo, 1997.

SMITH, W. A., " The Role of Piezocomposites in Ultrasonics", Ultrasonics Symposium . p 755-766, 1989

SINHA, K.S. "Scratching of Materials and Applications", San Diego - US, Elsevier Ed., 2006.

SREEJITH, P. S.; NGOI, B. K. A., 2002, "New Materials and Their Machining", Int.J. Adv. Manuf. Technol., no. 18, pp. 537-544.

STACHOWIAK, G.W., "Engineering tribology", Boston-US, Butterworth-Heinemann, 2001.

TAKEUCHI Y., KIMURA K., KOMAZAWA M., "Method of fabricating a piezoelectric/electrostrictive actuator", US Patent Number 5622748, 1997.

TIMOTEO, 2007, "Estudo do Processo de Corte de Cerâmicas Piezelétricas com Discos Adiamantados para a Fabricação de Piezocompósitos", Dissertação de Mestrado, São Paulo - Brasil, Escola Politécnica da Universidade de São Paulo, 2007 
WATANABE T. "Optimization Quartz Crystal Slicing Conditions using Multi-WireSaw" , IEEE Internacional Frequency Control Symposium and PDA Exhibition, p. 386-392, 2002

WILLIAM I. C., ALBERT J. S., RICHARD L. L., SAMUEL B. M. , "Fixed abrasive diamond wire machining-part II: experiment design and results ", International Journal of Machine Tools \& Manufacture 43 (2003) 533-542.

WILLIAM I. C., ALBERT J.S., SAMUEL B. M., HARDIN C.W., RICHARD L. L., "Fixed abrasive diamond wire machining-part I: process monitoring and wire tension force" International Journal of Machine Tools \& Manufacture 43 (2003) 523-532.

WILLIAM I. C., "Fixed-Abrasive Diamond Wire Saw Machining", North Carolina - US, 2001. 